\title{
Pass-through of $\mathrm{CO}_{2}$ emission costs to hourly electricity prices in Germany
}

Author: Beat Hintermann

University of Basel, Faculty of Business and Economics

Peter Merian-Weg 6

4002 Basel, Switzerland

b.hintermann@unibas.ch

Tel: +41 61267 3339; Fax: +41612673340 


\begin{abstract}
I estimate the level of emissions cost pass-through to hourly wholesale electricity prices in Germany, based on spot market data. I control for contemporaneous shocks to demand and supply by constructing a detailed supply curve for fossil generation, and intersecting it with residual demand for fossil-based electricity for every hour. Determining the marginal generator allows me to use marginal fuel and allowance costs (rather than prices) as explanatory variables in order to identify the level of cost pass-through directly and with a high level of precision. I find that allowance costs are passed through to electricity prices completely (or nearly completely) on average, but that the degree of pass-through varies over the load curve. My results suggest that there is no economic reason for free allowance allocation to the German electricity sector, and thus support the updated allocation rules in Phase 3 of the European Union Emissions Trading Scheme.
\end{abstract}




\section{Introduction}

The European Union Emissions Trading Scheme (EU ETS) is the largest emissions trading system to date, with an emissions cap of around 2 billion tons of $\mathrm{CO}_{2}$ per year that includes emissions from the most energy-intensive industrial sectors and accounts for around $40 \%$ of the EU's total $\mathrm{CO}_{2}$ emissions. The fiscal impact of this type of climate legislation resides with the firms that have to surrender allowances to cover their emissions, net of any free allowances they receive from their governments. Assessing the incidence is more complicated. Emission allowances are a necessary input for production that generates $\mathrm{CO}_{2}$ emissions as a by-product, and we would therefore expect the EU allowance (EUA) price to be reflected in product prices, just like the price of any other input, and independent of the method of allowance allocation.

The current market value of the aggregate emissions cap is around 12 billion euro per year; at its peak in early 2006, it exceeded 60 billion euro, corresponding to around $0.6 \%$ of the EU's GDP. ${ }^{1}$ From a public finance point of view, EU governments should secure this economic rent by selling all allowances and using the revenue to lower existing distortionary taxes (Bovenberg and Goulder, 1996). But this has not been done. During the first two market phases (2005-2007 and 2008-2012), almost the entire cap was allocated to firms free of charge. In the current third market phase (2013-2020), electricity generators in the EU-15 no longer receive a free allocation of allowances. However, about half of the total cap continues to be given away for free, to firms in exposed sectors as well as to electricity generators located in the more recent EU members. ${ }^{2}$ Therefore, the economic costs of the EU ETS was, and to a large extent still is, borne by taxpayers that do not receive the full tax rebate, and due to the tax-interaction effect, the total burden is inefficiently high (Parry, 1995). Considering the size of the program, an appraisal of its incidence is highly policyrelevant, also in the light of other emission permit markets that have been (or will be) set up elsewhere. In the current paper, I show that the incidence of the EU's carbon policy largely falls on consumers.

\footnotetext{
${ }^{1}$ The emissions cap for stationary sources is reduced by $1.74 \%$ of the average cap in phase 2 every year, which corresponds to an annual reduction by 38.2 million $\mathrm{tCO}_{2}$, implying that the EUA price will likely increase again over time. Currently, there is a debate in the EU about increasing the rate at which the cap is "melted" in order to reach the climate goals set for 2050.

${ }^{2}$ Ellerman et al. (2016) provide a review of the first two phases of the EU ETS; for a detailed description of the changes in the method and extent of free allocation between phase 2 and phase 3, see Sartor et al. (2015).
} 
There has been a lengthy policy debate about the merits of free allowance allocation to the industries included by the EU ETS, and a series of economic papers discuss this issue from various perspectives (Grubb and Neuhoff, 2006; Hepburn et al., 2006; Neuhoff et al., 2006). The "industry-friendly" argument claims that in order to avoid carbon leakage via a relocation of production activities to non-EU countries, and to maintain the international competitiveness of EU firms, the latter had to be allocated a significant share of emission allowances for free. This argument hinges on incomplete pass-through: If firms absorb a part of the allowance cost by lowering their profit margin, then (some) free allocation may be justified due to carbon leakage and protectionist arguments. If, on the other hand, firms fully pass on their allowance costs to consumers, free allocation simply constitutes a transfer from taxpayers to firms without ancillary benefits in the form of protecting domestic jobs or avoiding leakage. ${ }^{3}$

In this paper, I estimate the degree of allowance cost pass-through to hourly wholesale electricity prices in Germany. A number of earlier papers have estimated the degree of allowance cost pass-through to consumer prices, most of them focusing on electricity markets. ${ }^{4}$ Sijm et al. (2006) report positive rates of cost pass-through using OLS regressions on electricity spreads for 2005, based on daily future prices, in the order of 60-117\% for Germany, and of $64-81 \%$ for the Netherlands. Sijm et al. (2008) extend this analysis and find positive but incomplete allowance cost pass-through for Germany, France, the Netherlands and Sweden, and (possibly) full pass-through for the United Kingdom. Other papers measuring allowance cost pass-through based on price or spread regressions include Chernyavs' ka and Gulli (2008) and Honkatukia et al. (2013). However, regressing electricity prices on input prices can lead to biased estimates if the heat rate and the emission intensity of the marginal generator are correlated with fuel and allowance prices. If the merit order is sensitive to prices, such a correlation would be expected. To avoid this problem, I regress electricity prices on marginal input costs, rather than input prices.

\footnotetext{
${ }^{3}$ Whereas it is clear that no free allocation is needed if firms pass on all their allowance costs, the reverse argument is not obvious. Even if firms only pass on a part of their allowance costs by reducing their profit margin, the very existence of this margin implies some economic rents e.g. from imperfect competition, which the government may or may not want to protect. From a political economy point of view, incomplete pass-through requires some free allocation in order to avoid firms' opposition to the introduction of climate regulation.

${ }^{4}$ An exception is the analysis by Smale et al. (2006) who focus on the other sectors included in the EU ETS and find pass-through rates that are lower than for the electricity market, and which depend on an industry's exposure to competition from outside the EU.
} 
Another strand of the literature has focused on the long-term relationship between electricity, fuel and allowance prices using a cointegration framework, based on the concern that these prices may be determined jointly in the long run (Fell, 2010; Fell et al., 2015; Fezzi and Bunn, 2010; Lo Prete and Norman, 2013; Zachmann and von Hirschhausen, 2008). The consensus is that prices for inputs and electricity share a common trend. In these models, the effect of a change in an input price on the electricity price has to be computed using impulse-response functions, which tend to be sensitive to the inclusion of additional control variables or lags in the underlying model, and also to have large confidence intervals. Also, the cointegration models mentioned above all rely on futures data. This makes the analysis independent of contemporaneous shocks to the demand and supply of electricity, but the downside is that in suppressing such shocks, models based on futures data lose a source of variation that is very useful in identifying the level of cost pass-through.

My paper is most closely related to that by Fabra and Reguant (2014), who measure the pass-through of emissions costs in the Spanish electricity market based on disaggregated bidding data. Using data from the first 14 months of the EU ETS, they find that firms pass on emissions costs fully during peak hours, but not during offpeak hours, with point estimates of around $110 \%$ and $60 \%$, respectively. ${ }^{5}$ They furthermore show that Spanish electricity prices include a markup, but that this markup does not respond to cost shocks as a consequence of inelastic demand and a high correlation of cost shocks across firms.

Because individual bid data is not publicly available for the German electricity market, I build a detailed hourly dispatch model for electricity by relying on publicly available information about generation capacity, and about electricity demand and supply including generation by "must-run" sources such as renewable and nuclear energy, similar to an approach by Borenstein et al. (2002). This model allows me to identify the marginal generating unit (MGU) and compute its allowance and fuel costs, which I then use to estimate the level of cost pass-through. I find that allowance costs are passed through completely, or near completely, to wholesale electricity prices overall, with the confidence interval for the base model over all hours ranging from $81 \%$ to $111 \%$. This suggests that a free allocation of emissions permits is simply a gift to firms, as they are already reimbursed for their emissions costs by consumers,

\footnotetext{
${ }^{5}$ The point estimates and confidence intervals vary across their different models (Table 2 on p. 2884). The first four models indicate a cost pass-through of $70 \%-140 \%$ during peak hours, and of $28 \%-97 \%$ during offpeak hours.
} 
and it supports the EU's policy change to zero free allocation to electricity producers in the EU-15 countries.

When I allow pass-through to differ across hours, I find that allowance costs are passed through more (less) than completely during periods of high (low) demand. In contrast, fuel costs are passed through more evenly, which leads to differential cost pass-through that is statistically significant. This result is robust to the model specification, and also consistent with the results of Fabra and Reguant (2014), who find that Spanish firms do not pass on fuel costs to the same degree as allowance costs. A possible reason is that due to the presence of transactions costs and long-term contracts for fuels, the spot prices do not perfectly represent firms' opportunity costs related to fuel use. In contrast, emission allowances can be bought and sold at very low transaction costs. The heterogeneity of cost pass-through across hours and input types implies that electricity prices do not, or not always, reflect marginal production costs; however, it has no implication for the incidence of carbon policy, because costs are passed on fully on average.

The next section defines the concept of cost pass-through and introduces the empirical model. Section 3 discusses the market environment and presents the data, along with the computation of marginal input costs. Section 4 contains the results, and Section 5 concludes.

\section{Estimation of cost pass-through}

In this section, I define cost pass-through in the electricity market and present the empirical model to estimate it.

\subsection{Cost pass-through in electricity markets}

Let $P$ refer to the electricity price, and $M C$ refer to the marginal cost of producing another Megawatt hour (MWh) of electricity. The extent to which a change marginal costs is transferred into a change in the electricity price depends on the degree of competition and on the price responsiveness of demand and supply.

Figure 1 illustrate cost pass-through for different market structures. Panel (a) shows the case of perfect competition and linear inverse demand and supply (=marginal cost) curves. 
The initial equilibrium is at $\left(\mathrm{Q}_{0}, \mathrm{P}_{0}\right)$. If the price of allowances or fuel increases, the marginal cost of generation increases by $\triangle M C$. Due to the demand response, the output price increases by $\Delta P \leq \Delta M C$. The rate of cost pass-through is given by

$$
\frac{\Delta P}{\Delta M C}=\frac{\Delta P}{\Delta P+\Delta S}=\frac{-\Delta Q D_{q}}{\Delta Q S_{q}-\Delta Q D_{q}}=\frac{-D_{q}}{S_{q}-D_{q}} \leq 1
$$

where $D_{q}<0$ and $S_{q}>0$ refer to the slope of the (inverse) demand and marginal cost function, respectively, and $\Delta S$ is the difference in the marginal cost function as the quantity changes. With inelastic demand or infinitely elastic supply, $\Delta P / \Delta M C=1$, such that allowance costs are fully passed through to the electricity price. In general, cost pass-through in a perfectly competitive market decreases with the change in demand, and with the slope of the marginal cost function.

Figure 1: Cost pass-through under different market structures

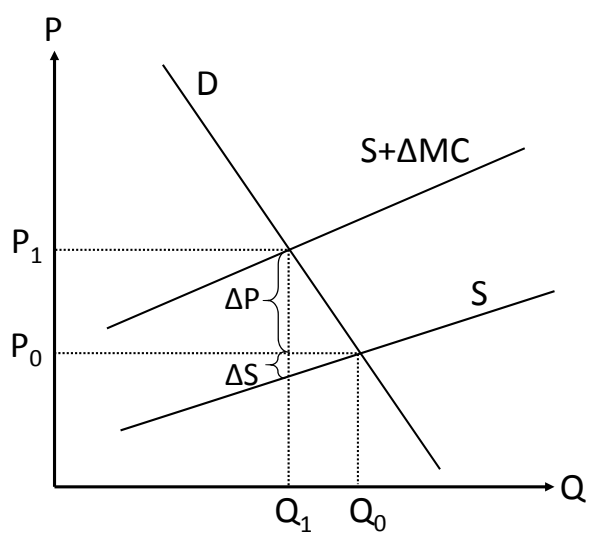

(a)

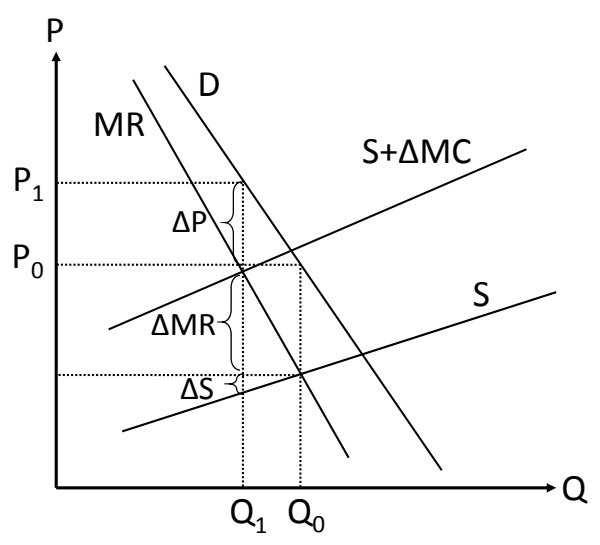

(b)

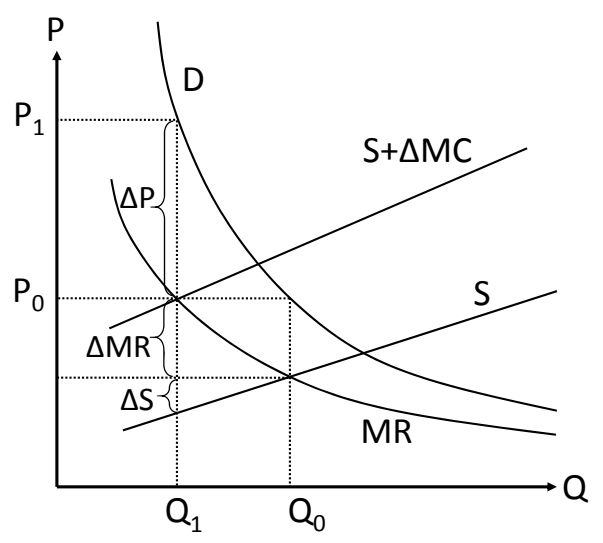

(c)

With imperfect competition, firms set their marginal costs equal to marginal revenue, as illustrated in panel (b). The rate of cost pass-through is then given by

$$
\frac{\Delta P^{M}}{\Delta M C}=\frac{\Delta P^{M}}{\Delta S+\Delta M R}=\frac{-D_{q}}{S_{q}-M R_{q}}
$$

where $M R_{q}$ is the slope of the marginal revenue function. Since the marginal revenue function is steeper than the demand curve, it follows that $(2)<(1)$. Intuitively, cost pass-through is lower if the output market is not competitive, because the monopolistic (or oligopolistic) firm absorbs a part of the cost increase by lowering its profit margin.

Eqs. (1)-(2) imply that pass-through below unity can occur due to either a demand re- 
sponse, imperfect competition, or a combination of the two. Short-term demand for electricity is most likely inelastic, because it is the sum of demand by retailers (who face a completely price-insensitive demand by consumers) and industry. Demand for wholesale electricity by the latter may be somewhat elastic, because plants can ramp production up and down, but this entails potentially large opportunity costs.

Expressions (1) and (2) hold as long as the demand curve is linear. In contrast, if the demand curve is sufficiently curved (e.g., if demand is iso-elastic), the marginal revenue curve is flatter than the demand curve, as illustrated by panel (c) in Figure $1 .^{6}$ In this case, cost pass-through under imperfect competition will be more than complete, because the markup increases as the equilibrium level of output decreases. This situation may be relevant during periods of very high electricity demand.

Finally, note that there exist an alternative concept for cost pass-through. In international economics, pass-through is usually measured as the effect of a change in a particular input price (or currency) on output prices (for a review, see Burstein and Gopinath, 2014). Under this definition, input substitution lowers the rate of pass-through. Linn et al. (2014) apply this concept to electricity prices in the US and report a variation in the pass-through of the gas price decrease across regional markets and load periods, along with changes in emissions. The underlying reason is the heterogeneity in the number of hours during which gas is the price-setting technology. In contrast, the composition of inputs does not affect the rate of "cost-based" pass-through as defined in this subsection, unless it is accompanied by a change in the markup.

\subsection{Empirical model}

The electricity price $P^{E}$ at time $t$ is the sum of fuel costs $(F C)$ and allowance costs $(A C)$ of the marginal generating unit (MGU), a markup $\mu$ (all of which depend on demand $Q_{t}$ ), and

\footnotetext{
${ }^{6}$ Expression (2) is based on linear demand and supply functions. More generally, the slope of the MR function is steeper than the slope of the demand function if $2 D_{q}+Q D_{q q}<D_{q}$ or $-D_{q q} Q / D_{q}<1$, i.e. if the elasticity of the slope of the inverse demand function is less than unity. This is trivially the case for linear demand because $D_{q q}=0$, but this condition does not generally hold. For example, consider the case of iso-elastic demand with $D=\alpha Q^{-1 / \beta}$, with $\alpha>0, \beta>0$. The elasticity of the slope of demand is then equal to $-D_{q q} Q / D_{q}=1+1 / \beta>1$. For a more detailed discussion of pass-through under imperfect competition, see Seade (1985).
} 
a constant that reflects variable costs that are independent of fuel and allowance costs:

$$
P_{t}^{E}=c+\alpha_{F} \cdot F C_{t}+\alpha_{A} \cdot A C_{t}+\mu_{t}
$$

The fuel and allowance costs of the MGU depend on its heat rate $h_{t}^{m}$ (measured in MWh fuel/MWh electricity), the emission factor $e f^{m}$ of the fuel associated with the MGU (a physical constant measured in $\mathrm{tCO}_{2} / \mathrm{MWh}$ fuel), and prices for fuel and allowances:

$$
\begin{aligned}
& F C_{t}=h r_{t}^{m} \cdot P_{t}^{F, m} \\
& A C_{t}=h r_{t}^{m} \cdot e f^{m} \cdot P_{t}^{A}
\end{aligned}
$$

Because I do not observe the true fuel and allowance costs of the MGU, I estimate them based on a merit order model (see below), which introduces a measurement error. I also do not observe the markup. For estimation purposes, (3) therefore becomes

$$
\begin{aligned}
& P_{t}^{E}=s_{0}+\alpha_{F} \hat{F C_{t}}+\alpha_{A} \hat{A C_{t}}+D_{t} \Gamma+\epsilon_{t} \\
& \text { with } \quad s_{0}=c+\bar{\mu} \\
& \\
& \qquad \begin{array}{l}
F C_{t}=F C_{t}+e_{t}^{F} ; \quad \hat{A C_{t}}=A C_{t}+e_{t}^{A} \\
\epsilon_{t}=u_{t}+\left[\mu_{t}\left(Q_{t}\right)-\bar{\mu}\right]-\alpha_{F} e_{t}^{F}-\alpha_{A} e_{t}^{A}
\end{array}
\end{aligned}
$$

There are two problems with estimating (6) by OLS. First, if demand is price-sensitive, the identity of the marginal generator (and thus its heat rate and its emissions factor) is jointly determined with the electricity price, rendering fuel and allowance costs endogenous. And second, the presence of the measurement errors $e_{t}^{F}$ and $e_{t}^{A}$ means that even if demand were completely inelastic, the coefficient estimates for $\alpha_{F}$ and $\alpha_{A}$ will be biased because $\hat{A C}$ and $\hat{F C} C_{t}$ are correlated with the error term by construction. ${ }^{7}$

To address these problems, I employ an instrumental variable (IV) estimation approach, with fuel and allowance prices serving as instruments. These instruments are valid if they are (i) correlated with fuel and allowance costs, which is true by construction of (4)-(5), and (ii) uncorrelated with the error term $\epsilon_{t}$. Whether the latter condition holds cannot be tested

\footnotetext{
${ }^{7}$ If two or more explanatory variables are measured with error, all coefficients are biased, and the direction of the bias is unknown and in fact unknowable (see e.g. Greene, 2002, p. 85).
} 
directly. Instead, I provide theoretical arguments for why I expect it to hold in the following, and use an over-identified model (or rather, a series of over-identified models) that allows me to test for the over-identifying restrictions they impose.

The error term in (6) is likely to be driven by mean-reverting shocks in demand and supply. For example, a sudden decrease in wind power could lead to a spike in electricity prices beyond the marginal cost increase according to the merit order, if firms are unwilling to switch on a coal generator only to ramp it down again a few hours later. The error may also contain a measurement error (if the true MGU differs from the one computed based on my dispatch model), and a change in the markup. In contrast, nonstationary changes in demand and supply, e.g. due to an increase in the installed renewables capacity in economic activity, should lead to an adjustment of the merit order, and thus not to a change in the contemporaneous error term. The validity of the exclusion restriction therefore hinges on the (lack of) correlation between fuel and allowance prices and short-term shocks in the demand and supply of electricity.

Fuel prices are determined on a global level and thus unlikely to be related with temporary shocks in the German electricity market. The early empirical literature reported a correlation between weather and the allowance price, but only during Phase I of the EU ETS. Since Phase II and the possibility of allowance banking, the allowance price has been found to be affected by changes in stationary variables such as fuel prices or hydro reservoir levels, but not by mean-reverting shocks (Aatola et al., 2013; Lutz et al., 2013). The theoretical reason behind these findings is that with allowance banking, the price is determined by the cumulative expected allowance demand until infinity, which depends on changes in nonstationary variables only. ${ }^{8}$ For a literature review about allowance price determination in the EU ETS, refer to Hintermann et al. (2016).

Finally, the vector of dummies $D_{t}$ in (6) includes dummies for hours when heat-optimized combined power and heat $(\mathrm{CPH})$ plants are marginal, and when residual demand is negative. ${ }^{9}$ In some specifications I also add yearly, monthly and weekday-hour dummies. In all models, the null hypotheses of complete and equal pass-through for fuel and allowance costs

\footnotetext{
${ }^{8}$ Hintermann (2010) expresses the effect of a mean-reverting shock as a function of the time left to the end of the system, which was December of 2007 during Phase I of the EU ETS. With unlimited banking, the relevant time horizon is infinity, such that the effect of mean-reverting shocks on the permit price is nil.

${ }^{9}$ Negative residual demand occurs in 2013 only, and usually corresponds to negative electricity prices. During these hours, producers pay a price for keeping their plants online due to startup and ramping costs.
} 
are $\alpha_{F}=\alpha_{A}=1$.

As an alternative to model (6), I also estimate cost pass-through using the OLS estimator on allowance and fuel prices, rather than the IV estimator for marginal input costs, which is the natural approach if the identity of the MGU is not known and the method of choice in most of the pass-through literature: ${ }^{10}$

$$
P_{t}^{E}=b_{0}+\sum_{F=C, G, O} \beta_{F} P_{t}^{F}+\beta_{A} P_{t}^{A}+\beta_{d} D_{t}+\beta_{x} X_{t}+\nu_{t}
$$

The indices in the summation term refer to coal, natural gas and oil, and the vector $X_{t}$ includes controls for contemporaneous shocks to the demand and supply of electricity. As in (6), the constant includes the mean markup, whereas the hourly deviation in the markup is part of the error term $\nu_{t}$.

To derive the identifying restrictions required to determine the level of cost pass-through from the price coefficients, I re-write the data generating process (3) using (4)-(5) as

$$
P_{t}^{E}=c+\mu_{t}+\alpha_{F} \cdot \sum_{F=C, G, O} h r_{t}^{F, m} \cdot P_{t}^{F}+\alpha_{A} \cdot \sum_{F=C, G, O} h r_{t}^{F, m} \cdot e f^{F} \cdot P_{t}^{A}
$$

where $h r_{t}^{F, m}$ is equal to the heat rate of the MGU if fuel type $F$ is marginal, and zero otherwise. Let $\overline{h r}^{F} \equiv \sum_{T} h r_{t}^{F, m} / T$ refer to the unconditional average heat rate, and $\overline{h r_{m}^{F}} \equiv$ $\sum_{T} h r_{t}^{F, m} / T_{F}$ to the average heat rate conditional on fuel $F$ being on the margin, where $T_{F}$ is the number of hours during which fuel type $F$ is price-setting. If the heat rate is independent of input prices, it can be replaced by its mean. ${ }^{11}$ In this case, OLS on fuel and allowance prices yields unbiased estimates that correspond to

$$
\begin{aligned}
& \hat{\beta}_{F}=\hat{\alpha}_{F} \cdot \overline{h r}_{m}^{F} \cdot\left(T_{F} / T\right) \\
& \hat{\beta}_{A}=\hat{\alpha}_{A} \cdot \sum_{F} \overline{h r_{m}^{F}} \cdot e f^{F} \cdot\left(T_{F} / T\right) \quad \text { for } \quad F=C, G, O
\end{aligned}
$$

\footnotetext{
${ }^{10}$ Examples include Fell (2010); Fell et al. (2015); Fezzi and Bunn (2010); Honkatukia et al. (2013); Sijm et al. $(2008,2006)$. Note that these papers estimate cost pass-through based on electricity futures, which removes the need to control for contemporaneous shocks to demand and supply, but which does not allow to study cost pass-through on an hourly level.

${ }^{11}$ To see this, suppose we regress a vector $Y$ on a vector $X \equiv W \odot Z$, where " $\odot$ " is the pointwise multiplication operator. If $W$ and $Z$ are independent, it follows that $E[W \odot Z]=E[W] \cdot E[Z]$, such that we can regress $Y$ on $\tilde{X} \equiv E[W] \cdot Z$. Note that the independence assumption applies to the unconditional average heat rate, which is affected by the number of hours a technology is price-setting.
} 
Identification is achieved by adding the restriction that the marginal generation shares $T_{F} / T$ have to sum to one. Solving (9) for the marginal generation shares and substituting into the identifying restriction and (10) leads to the following hypotheses of complete cost pass-through:

$$
\begin{array}{lll}
\tilde{H}_{0}^{F}: & \alpha_{F}=\sum_{F} \frac{\beta_{F}}{\overline{h r_{m}^{F}}}=1 ; & \tilde{H}_{1}^{F}: \alpha_{F} \neq 1 \\
\tilde{H}_{0}^{A}: & \alpha_{A}=\beta_{A} \cdot \frac{\sum_{F} \beta_{F} / \overline{h r}}{\sum_{F} \beta_{F} \cdot e f^{F}}=1 ; & \tilde{H}_{1}^{A}: \alpha_{A} \neq 1
\end{array}
$$

A rejection of the null hypotheses (11)-(12) is consistent with incomplete pass-through, but also with a violation of the underlying assumptions. If the heat rate of the marginal generator is not independent of input prices, then OLS on (8) yields biased estimates, because input prices are correlated with the error term (see Appendix A1). Since the merit order depends on fuel prices, and the heat rate depends on the merit order, the independence assumption is not likely not hold. Whether this is quantitatively relevant is an empirical question, which I address by comparing the estimates for cost pass-through based on prices with those based on marginal costs.

Lastly, some of the empirical literature has worked with fuel spreads rather than electricity prices (see e.g., Sijm et al., 2008, 2006) and has regressed these spreads on allowance prices, which requires an assumption about a particular technology being on the margin in a given load period, as well as an average heat rate for that technology. In the Appendix I show that this procedure is even more susceptible to bias than the price-based approach.

\section{Market environment and data}

In this section, I describe the German electricity market, present the data, and describe the computation of marginal input costs.

\subsection{The German electricity market}

The German electricity market was liberalized in 2005 in the context of EU-wide energy market reforms. Transmission remains a regulated natural monopoly, but wholesale market 
prices are unregulated. There are three types of markets: Forward, day-ahead, and intra-day. All three are wholesale markets in which suppliers of electricity sell power to retailers, and to large industrial consumers. In contrast, electricity retail prices are fixed over several months, such that cost pass-through to retail consumers cannot take place in the short run.

Of the three wholesale markets, the forward market is the largest by volume. The European Energy Exchange (EEX) offers standardized futures contracts for maturities of up to 6 years. Contracts are available separately for baseload and peak hours ( 8 a.m. to 8 p.m. on workdays) and are specified in terms of MW per relevant load period. ${ }^{12}$ Electricity futures are settled financially, based on the difference between the futures price and the day-ahead price that materializes throughout the delivery period.

In addition to the forward market, power is bought and sold for every hour of the following day on the European Power Exchange (EPEX). This day-ahead market is sometimes also referred to as the spot market. In this market, power suppliers, retailers and industrials balance out their forward positions based on their expected need for the next day. The individual demand and supply bids are aggregated into market demand and supply curves for every hour, and the hourly market-clearing price is established. Note also that there is just one aggregate supply curve and one aggregate demand curve, leading to a single generator being marginal at any hour. ${ }^{13}$ Transmission constraints are accommodated by means of intraday adjustments. In order to ensure that demand equals supply at each moment in time given the distribution of production, consumption and the existing transmission lines, the TSO is responsible for real-time balancing and thus has the ability to bring individual generators onand offline. Some of this balancing is market-based (the third market), but the liquidity in this intra-day market is very low. The remaining real-time adjustments are made by the TSO

\footnotetext{
${ }^{12}$ For example, the seller of a one-year baseload futures contract promises to supply one MW of electricity for each of the 8,760 hours of the next calendar year at the specified price, whereas the seller of a peak contract promises to supply 1 MW during peak hours only. To avoid confusion with the physical load, I use the terms "all hours" and "peak hours" (rather than baseload and peak load) when referring to time.

${ }^{13}$ Generally, there will be more than one marginal generators if there are binding transmission constraints. This is relevant e.g. in the US electricity markets. However, transmission constraints are explicitly ignored in the German day-ahead auctions and dealt with on an intra-day basis by the Transmission System Operator (TSO). As a rule, inframarginal generators that are forced off-line by the TSO are compensated according to the marketclearing price, whereas extramarginal generators that are forced to come online are compensated based on their (rejected) bid. Since firms do not know exactly when and where transmission constraints will be binding, and who will be forced offline or online in such a case, this system leaves little scope for price manipulation for generators that could potentially end up being marginal during a given hour. Since I'm interested in the marginal generator, strategic over-bidding for generators that are extramarginal with a high probability (in the hope of receiving this high price as a compensation if they are forced online) would have no impact on my results.
} 
based on system requirements.

The electricity markets in Europe are organized on a national level in the sense that firms can only place supply bids into their respective national market, which allows me to focus on the German generation portfolio only. Applying so-called "market coupling", exchanges use the available transmission capacity to minimize cross-border price differentials, whereas firms cannot place bids for cross-border transmission capacity themselves. ${ }^{14}$

\subsection{Data}

The sample period covers the period from January 1, 2010, to December 31, 2013. My dependent variable is the hourly day-ahead electricity price from EPEX. For input prices, I use the EUA spot price, the next-month CIF ARA coal price, the EGIX natural gas price index for Germany, and the price for FOB ARA gasoil with a sulphur content of $0.2 \%$, all of which are traded on EEX. ${ }^{15}$ As price information for inputs only exists for weekdays, I fill in prices for weekends and holidays with the last available price. I converted all prices into euros. In order to match up the electricity prices from the day-ahead market with actual delivery, I shifted the price data forward by one day such that delivery dates coincide. I accessed all prices via Thomson Reuters Eikon. Figure 2 shows daily input prices and the daily average of the electricity price. Summary statistics of all included variables are provided in Table 1.

To determine the residual demand for fossil-based electricity, I start with total demand for domestic electricity generation, which is the sum of hourly demand from consumers and industry, electricity use for pumped storage, and hourly net exports to other countries, all of which are obtained from ENTSO-E. ${ }^{16}$ From this total hourly generation, I subtract generation from sources that have low marginal costs and can therefore be assumed to run whenever the corresponding plants are not in maintenance. These "must-run" technologies include lignite,

\footnotetext{
${ }^{14}$ Market coupling between Germany, France, Benelux and NordPool has been instituted in 2010. Since May 2015, all markets across north-western Europe are integrated via multi-market coupling. For more information about market coupling in Europe, see www.epexspot.com/en/market-coupling, last accessed in March 2016).

${ }^{15} \mathrm{CIF}$ stands for cost, insurance and freight and means that the price is inclusive of these costs; in contrast, FOB is an acronym for free on board and indicates that shipment and insurance have to be paid by the buyer. ARA stands for entry into Europe at the ports of Amsterdam, Rotterdam or Antwerp. The EEX CIF ARA coal future is based on the API(2) index, which is computed using price information on all coal entering northwestern Europe by ocean freight. Since the coal spot market is not very liquid, the nearest-term future market is interpreted as the closest substitute.

${ }^{16}$ European Network of Transmission System Operators for Electricity, available at https://www.entsoe.eu/. Because of the inability of German suppliers to bid into the French market and vice versa, I treat net exports (=exports-imports) as exogenous.
} 
Figure 2: Daily prices for electricity, fuels and EUAs

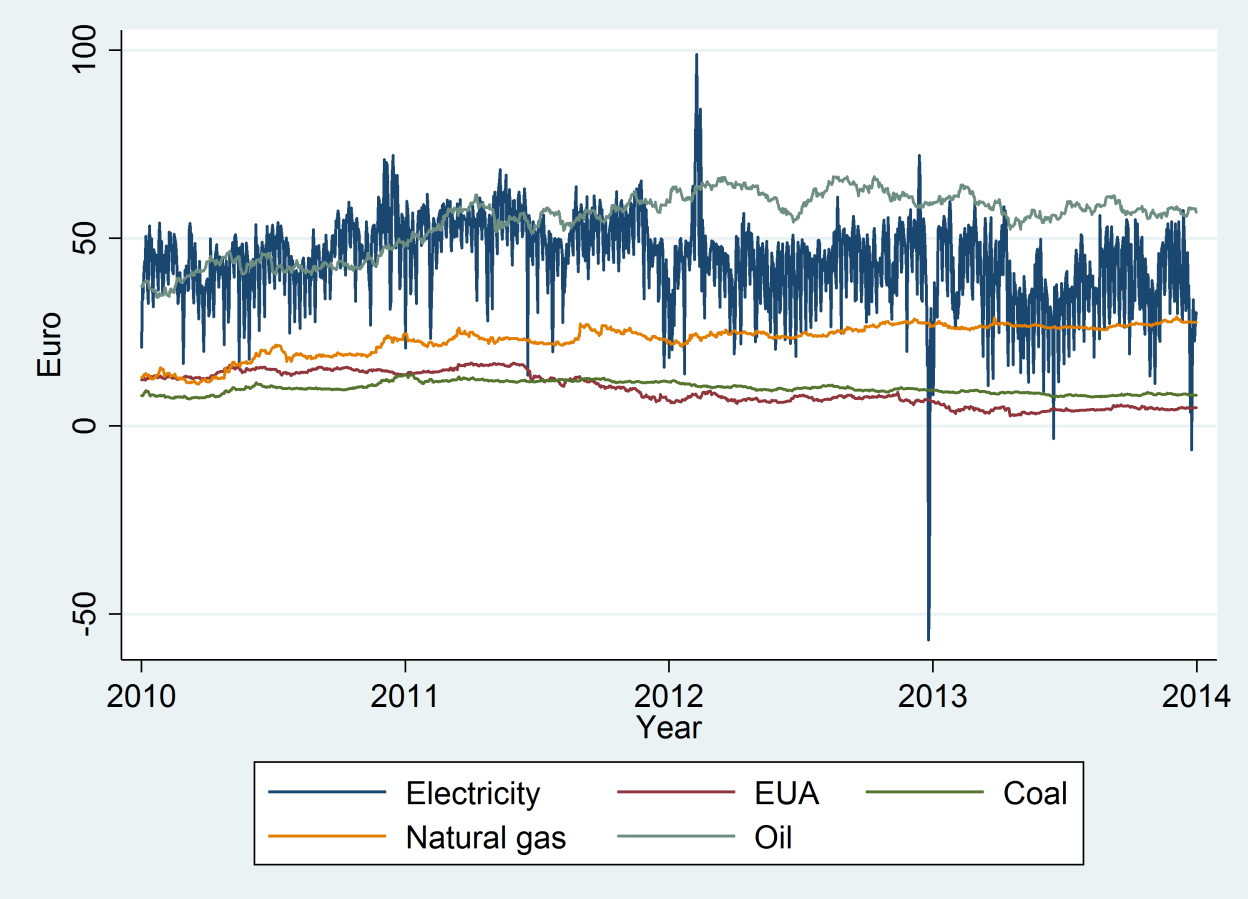

Source: Data from Thomson Reuters Eikon

nuclear, renewables (wind, solar, hydro and biomass) and waste incineration. ${ }^{17}$ Hourly production of electricity from must-run sources are provided by the EEX Transparency platform, with the exception of biomass and waste incineration, for which I divided monthly data from the German Federal Environment Agency among the number of hours per month. ${ }^{18}$ EEX also provides hourly information about planned outages by technology.

A problem that arises is that the hourly values for demand and generation by nuclear, hydro and lignite, aggregated up to the monthly level, do not exactly match up with the monthly values, which are more complete and correspond to annual totals. Reasons for the difference are net vs. gross generation and that some insular industrial nets are not included in the hourly values. In order to get consistent numbers, I calibrate everything to the level of the monthly data by multiplying the hourly values with a monthly correction factor for demand, and for generation by nuclear, lignite and hydro. In addition, I include an additive correction factor to include generation by "other" fossil generation (e.g., by peat or the non-

\footnotetext{
${ }^{17}$ Although lignite generation clearly has positive marginal fuel costs, lignite-based generators typically run continuously due to the very high startup and ramping costs; in fact, lignite generation in Germany is less variable than nuclear generation, as shown in Fig. 6 below. Also, since generation by biomass is typically associated with feed-in tariffs, I consider biomass as inframarginal, although the true marginal production costs may be considerable.

${ }^{18}$ Publication titled "Erneuerbare Energien in Zahlen", available at http://www.umweltbundesamt.de/themen/klimaenergie, last accessed in Feb. 2014.
} 
Table 1: Descriptive statistics $(\mathrm{N}=35$ '064)

\begin{tabular}{|c|c|c|c|c|c|}
\hline & Unit & Mean & St.dev. & Min & Max \\
\hline Elec_spot & Euro/MWh & 43.97 & 16.46 & -221.99 & 210.00 \\
\hline EUA & Euro/tCO2 & 9.79 & 4.32 & 2.68 & 16.84 \\
\hline Gas & Euro/MWh & 23.15 & 4.16 & 11.29 & 29.06 \\
\hline Coal & Euro/MWh & 10.16 & 1.54 & 7.19 & 13.83 \\
\hline Gasoil & Euro/MWh & 54.56 & 7.95 & 34.37 & 66.46 \\
\hline Demand & MWh & 61'662 & $11^{\prime} 762$ & 33'991 & $92 ' 174$ \\
\hline Net exports & MWh & $2^{\prime} 015$ & 3'595 & $-9 ' 605$ & $14 ' 299$ \\
\hline Pumps & MWh & 880 & 672 & 0 & 1'791 \\
\hline Must_run & MWh & $42^{\prime} 629$ & 6'889 & $22 ' 879$ & $76 ' 859$ \\
\hline Nuclear & MWh & $12 ' 035$ & 3'029 & 4'066 & $19 ' 029$ \\
\hline Lignite & MWh & $15^{\prime} 822$ & 2'086 & 7'120 & $20 ' 849$ \\
\hline Other fossil & MWh & $1^{\prime} 710$ & 996 & 44 & 7'247 \\
\hline Solar & MWh & 2'598 & 4'375 & 0 & 30'324 \\
\hline Wind & MWh & $5^{\prime} 481$ & 4'965 & 95 & $32 ' 187$ \\
\hline Hydro & MWh & 2'550 & $1^{\prime} 418$ & 473 & $11 ' 776$ \\
\hline Biomass & MWh & 3'481 & 548 & 2'726 & $4^{\prime} 122$ \\
\hline Waste & MWh & 661 & 104 & 518 & 783 \\
\hline Correction & MWh & 860 & 826 & -988 & 3'097 \\
\hline Fuel cost MGU & Euro/MWh & 29.56 & 11.00 & 0.00 & 198.89 \\
\hline Carbon cost MGU & Euro/MWh & 7.34 & 3.59 & 0.00 & 15.11 \\
\hline$M C=F C+C C$ & Euro/MWh & 36.90 & 11.69 & 0.00 & 204.98 \\
\hline
\end{tabular}

Source: Thomson Reuters, ENTSO-E and own computations

biogenic part of garbage), which are not included in the hourly data, and to account for the difference between hourly and monthly numbers for renewable generation (mostly due to biomass) and net exports. ${ }^{19}$

The variation in daily electricity prices in Figure 2 far exceeds the variation in input prices, and the hourly price variation is even greater, ranging between EUR -222 /MWh to EUR 210/MWh. This variation mainly comes from fluctuations in total demand and the supply of "free" electricity via the generation of renewables, as shown in Figure 3.

Besides significant variation over time, electricity prices and residual demand also exhibit a pronounced intra-weekly variation. Figure 4 shows the average price for each hour of the week (starting with the hour from midnight to 1 a.m. on Monday), along with residual and total demand. The latter is known as the load curve, because it reflects the total electric load

\footnotetext{
${ }^{19}$ The means of the monthly scaling factors are 1.134 for demand, 1.007 for nuclear, 1.024 for lignite and 2.107 for hydro generation. For generation by other fossil fuels or biomass there is no underlying hourly series that could be scaled to monthly levels, such that an additive correction is necessary. For net exports, there are some months where the hourly and monthly totals do not have the same sign. Applying a multiplicative correction factor would switch the export balance for each hour, including those with a high net export or net import. Similarly, a proportional correction of renewables would to lead to some hours with unrealistically high levels of renewable generation.
} 
Figure 3: Daily averages for demand, generation by renewables and net exports

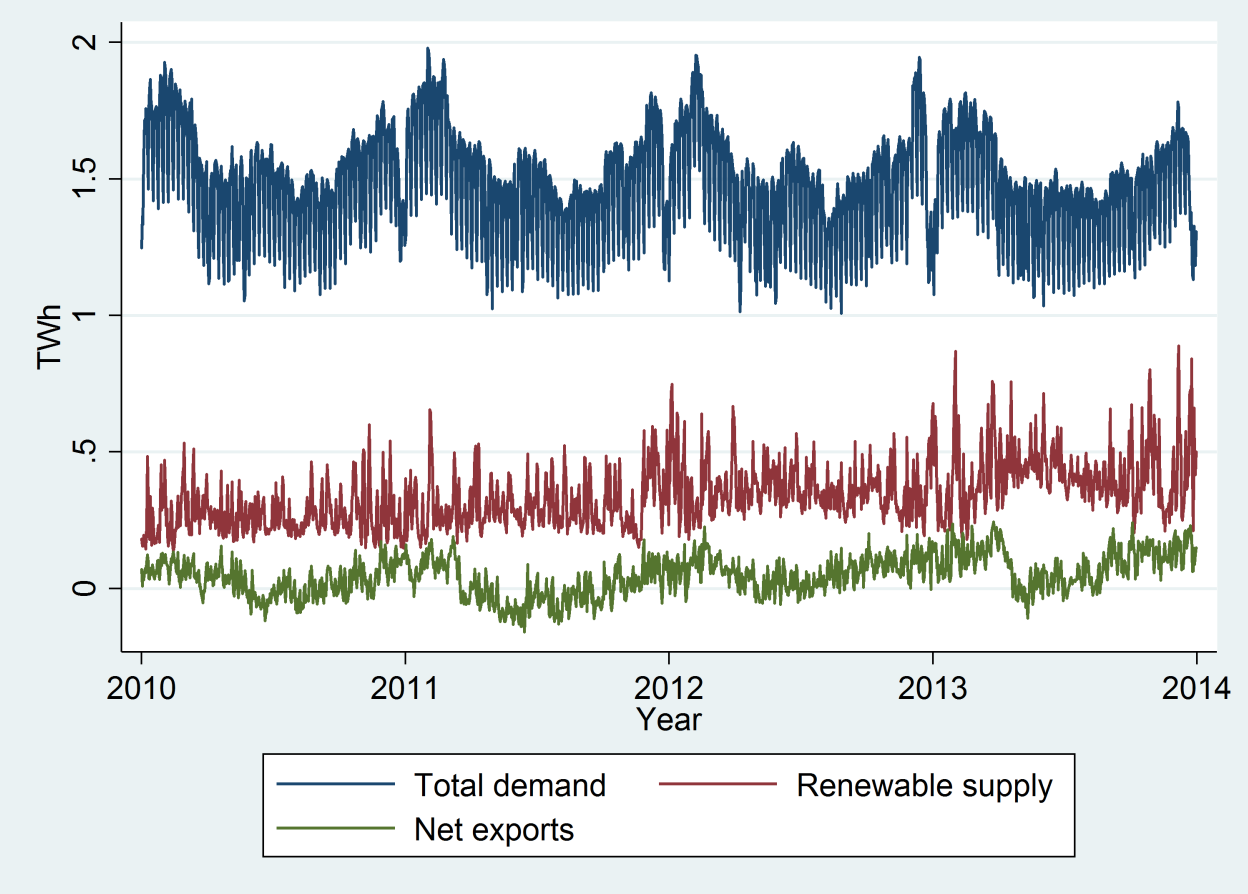

Source: ENTSO-E and Thomson Reuters

in the grid per hour. The figure shows that the influx of renewables occurs mainly during the day, with the effect of flattening the daily residual demand curve. Looking closely at the latter reveals a bimodal daily distribution (in contrast to the unimodal total demand), which corresponds to the two daily peaks in the hourly electricity prices.

\subsection{Computing the marginal fuel and allowance cost for each hour}

To compute marginal input costs, we need to identify the marginal generating unit (MGU), which requires the construction of a generation dispatch (or merit) order. ${ }^{20}$ I do this by intersecting hourly residual demand for fossil-based electricity with Germany's fossil-based generation portfolio. The merit order exhibits several sources of variation. It changes over the long run (i.e., months to years) due to additions, retirements or retrofits of generators. The variation in input prices can translate to a daily variation in the merit order. Finally, the merit order changes on an hourly basis due to planned outages and heat demand from combined power and heat $(\mathrm{CPH})$ plants. More details an be found in the Appendix.

\footnotetext{
${ }^{20}$ The merit order is the sequence according to which generators are brought online; in a liberalized market such as Germany, the merit order is typically based on least production cost, although firms may place supply bids above or below the marginal cost of production in order to stay inframarginal or extramarginal for a given hour, or in an effort to manipulate prices. This is the main source of measurement error in my model.
} 
Figure 4: Intra-week variation of prices, demand and supply by renewables

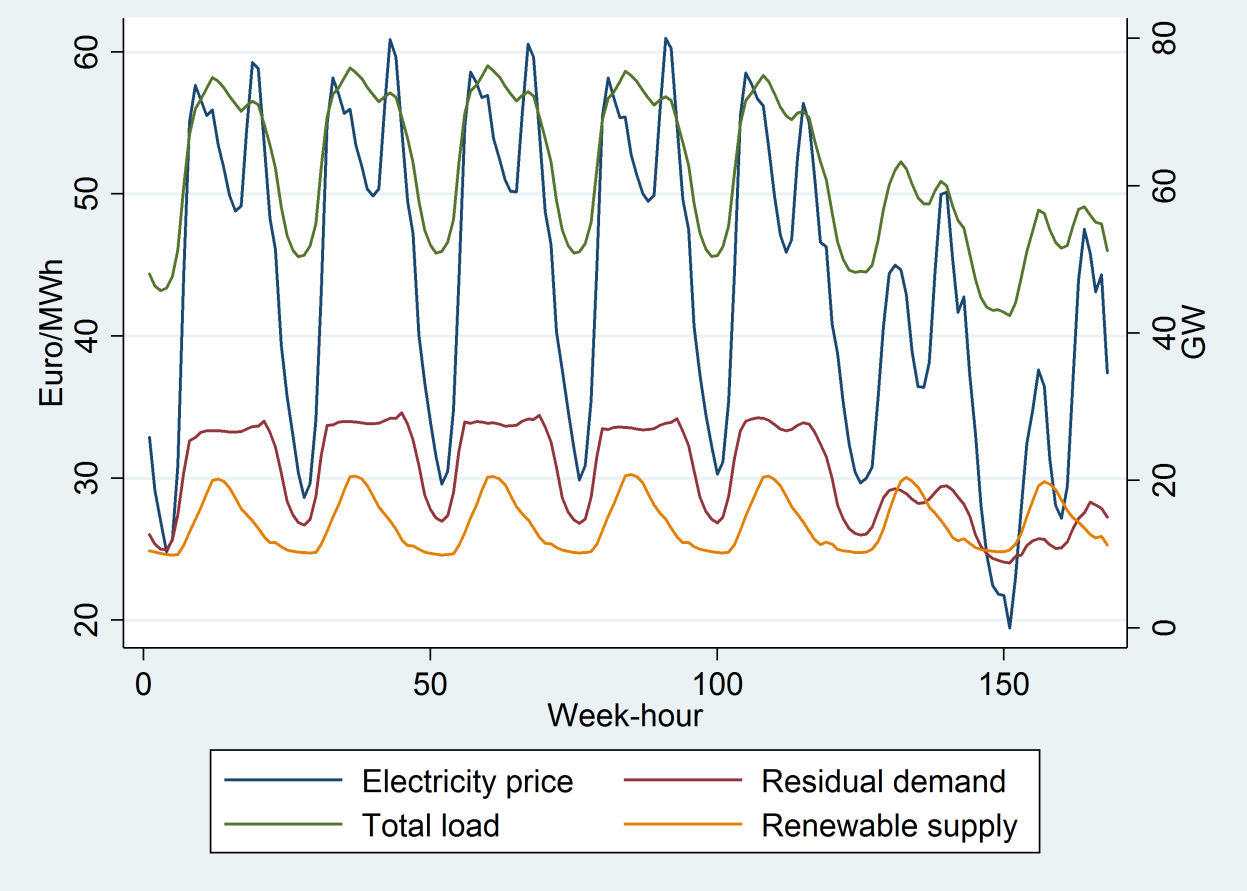

Source: Own computations based on data from ENTSO-E and EEX

As my main input for the generation portfolio, I use a dataset provided by the German Federal Environmental Agency, which contains information about all generators with an installed (gross) capacity of at least $100 \mathrm{MW}$ at the end of each calendar year. ${ }^{21}$ From this, I extract generators that use as fuel inputs hard coal, natural gas, oil and process gas. ${ }^{22}$ The information available includes the type of fuel, the technology, the year of construction and any major update or retrofit, and whether the generator is used to generate heat or electricity for industrial processes. Because the dataset contains no information about the heat rate of each generator, I compute it based on a set of empirical formulae that depend on fuel type, technology and plant age, as described in Appendix A2. I compute the fuel cost of each generator by multiplying the heat rate with the respective fuel price, and the emissions cost by multiplying the heat rate with the fuel-specific emission factor (taken from IPCC, 2006) and with the allowance price, as shown in (4)-(5). The merit order is formed by ranking generators based on total marginal costs (the sum of fuel and emissions costs).

I then make three types of adjustments to the generation portfolio. The first concerns

\footnotetext{
${ }^{21}$ http://www.umweltbundesamt.de/daten/energiebereitstellung-verbrauch/kraftwerke, last accessed in January 2014.

${ }^{22}$ Process gas (translated from the German term "Prozessgas") includes all burnable gases that originate as a byproduct of an industrial process, e.g. in the production of steel, coke and refined fuels or during mining. The German terms of the various process gases are Gichtgas, Konvertergas, Kuppelgas and Raffineriegas.
} 
the total generation capacity and is based on a comparison of the dataset from the Umweltbundesamt with a different dataset provided by the Federal Grid Agency, which includes a more complete list of generators down to an installed net capacity of $10 \mathrm{MW}$ but contains no information about the employed technology. I add the difference in capacities by fuel type to the Umweltbundesamt database, using the same technology mix and plant age distribution per fuel type as the one observed in the latter. ${ }^{23}$ Table 2 contains the generation capacity for 2013, along with the capacity adjustments and the average heat rate per fuel type and technology, weighted by the capacity of each generator.

Table 2: Fossil generation portfolio

\begin{tabular}{lccc}
\hline \hline & $\begin{array}{c}\text { Net capacity } \\
\text { (MW) }\end{array}$ & $\begin{array}{c}\text { Included adjustment } \\
\text { (MW) }\end{array}$ & $\begin{array}{c}\text { Heat rate } \\
\text { (MWh fuel/MWh elec.) }\end{array}$ \\
\hline Coal & 25,476 & -377 & 2.57 \\
Natural Gas & 26,974 & 4,206 & 2.10 \\
CCGT & 20,782 & 3,240 & 1.97 \\
OCGT & 3,580 & 558 & 2.84 \\
Conventional & 2,613 & 407 & 2.57 \\
Process Gas & 2,806 & 1,470 & 2.25 \\
CCGT & 1,370 & 327 & 2.05 \\
Conventional & 1,436 & 343 & 2.48 \\
Oil & 4,011 & 1,470 & 2.69 \\
OCGT & 1,792 & 671 & 3.01 \\
Conventional & 3,689 & 799 & 4.12 \\
\hline Total & 59,267 & 6,768 & 2.35 \\
\hline \hline
\end{tabular}

Note: Data from Umweltbundesamt and Bundesnetzagentur. Lignite plants are excluded. CCGT and OCGT stand for combined-cycle and open-cycle gas turbine, respectively.

The second adjustment pertains to outages. Operators may take generators offline for planned maintenance, to add them to the capacity reserve, or for strategic reasons. Outage information is collected by the TSO and made available on an hourly basis, aggregated by fuel type. One way to proceed would be to use the outage shares to reduce each generator's capacity for that hour. However, because the marginal input costs are a nonlinear function of capacity, and the average of a nonlinear function is not equal to the nonlinear function of the expected argument, I carry out a Monte-Carlo analysis similar to that employed by Borenstein et al. (2002). I randomly assign each generator a dummy equal to zero with a probability given by the share of the respective generation source that is unavailable at a particular hour,

\footnotetext{
${ }^{23}$ Available at www.bundesnetzagentur.de, last accessed in January 2014. For coal, the difference is entirely due to gross vs. net capacity (as there are no coal generators with a capacity of less than $100 \mathrm{MW}$ ), and I therefore multiply the coal capacity in the Umweltbundesamt database by 0.985 to match it to the net capacity provided in the Bundesnetzagentur datase.
} 
and equal to one otherwise, and multiply each generator's capacity with this dummy. ${ }^{24}$ I then compute the merit order, intersect it with residual demand for that hour and thus identify the marginal fuel and allowance costs (i.e., the fuel and allowance costs of the MGU). I repeat this procedure 200 times for each hour and then compute expected fuel and allowance costs to be used in (6) from the average:

$$
\begin{aligned}
& \hat{F C_{t}}=\frac{1}{200} \sum_{i=1}^{200} h r_{t}^{m, i} \cdot P_{t}^{F, m, i} \\
& \hat{A C_{t}}=\frac{1}{200} \sum_{i=1}^{200} h r_{t}^{m, i} \cdot e f_{t}^{m, i} \cdot P_{t}^{A}
\end{aligned}
$$

The third and final adjustment addresses the fact that a portion of electric generation comes from combined power and heat ( $\mathrm{CPH}$ ) plants, some of which are operated based on heat requirements rather than electric output. $\mathrm{CPH}$ plants are identified in the data, but whether a plant is operated based on heat or electricity needs is not observed. When ignoring heat-based operation, my dispatch model predicts less generation by natural gas, and practically no generation by oil, compared to actual output reported by fuel type reported on the monthly level. ${ }^{25}$ Based on information about annual electric generation by gas-fired $\mathrm{CPH}$ plants and monthly heat load curves for industry and households, I compute the amount of hourly $\mathrm{CPH}$ generation and move a portion of it to the bottom of the merit order by assigning it to an artificial generator with a marginal cost of 0.5 euro/MWh. To keep total generation capacity constant, I decrease the capacity of the remaining $\mathrm{CPH}$ generators accordingly. I do this in the context of the Monte-Carlo analysis described above, i.e. by randomly switching off $\mathrm{CPH}$ generators with a probability equal to the share of the CPH capacity occupied for heat generation during that hour. I calibrate the portion of $\mathrm{CPH}$ generation that is heat-optimized based on the actually observed monthly generation by gas and oil in 2013.

The resulting merit order for coal, gas and oil generation for a typical weekday in the summer of 2010 and the winter of 2013 is shown in Figure 5, for the hour 16:00-17:00.

\footnotetext{
${ }^{24}$ Suppose that $9 \%$ of coal capacity is unavailable in a given hour. Rather than reducing the capacity of all coal generators by $9 \%$ in that hour, I assign each coal generator a dummy equal to zero with a probability of 0.09, and equal to one otherwise. Due to the random nature of this procedure and the differences in installed capacities across generators, the available capacity during a particular iteration is generally not equal to the actually available capacity. On average, however, actual and simulated capacities will match up.

${ }^{25}$ This is a common problem in the literature that seeks to model electric dispatch in the presence of $\mathrm{CPH}$ generation; see e.g. Hirth (2013); Leuthold et al. (2012).
} 
Figure 5: Merit order and residual demand on 16.1.2013 (top) and 16.6.2010 (bottom)
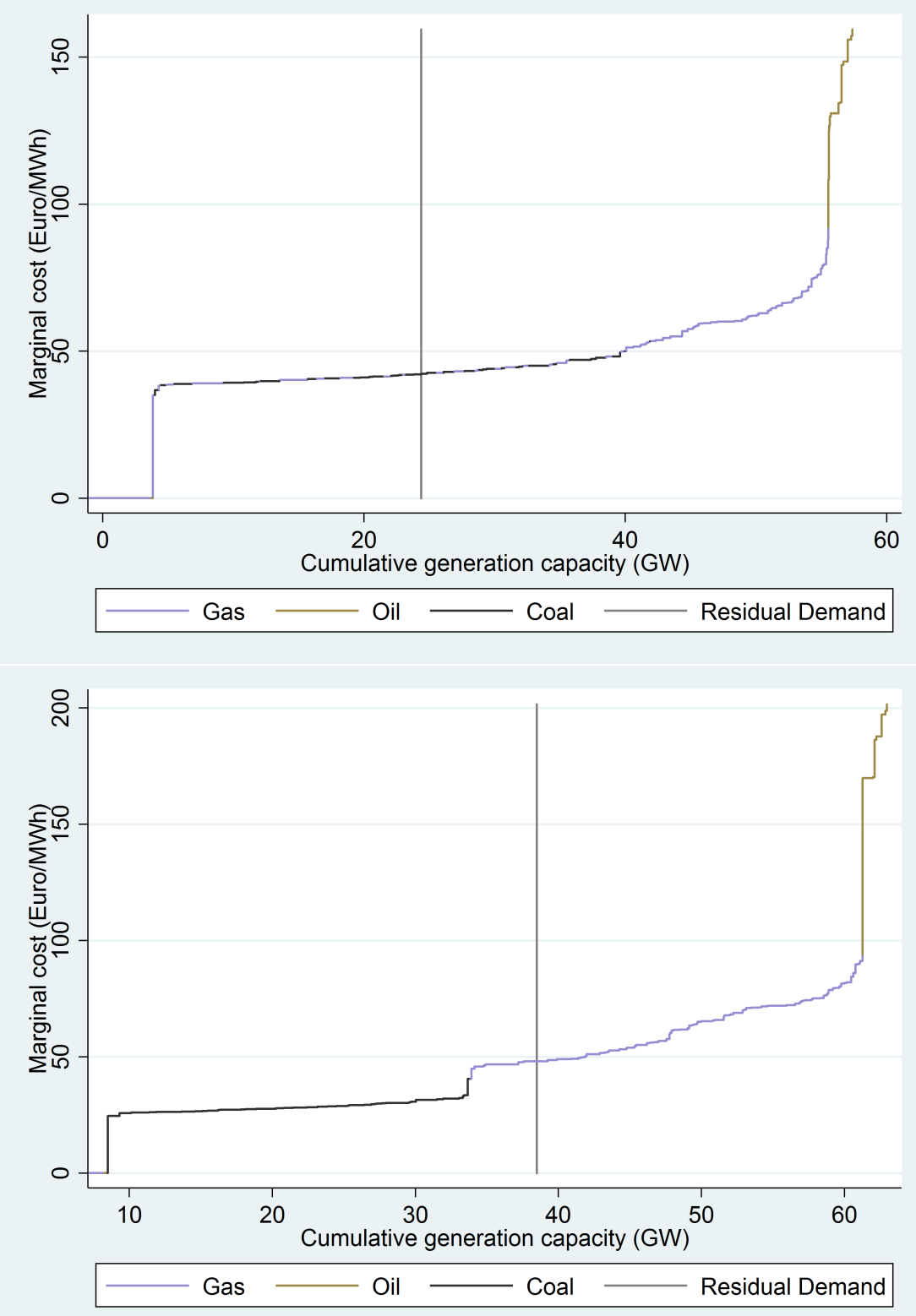

At the very bottom of the merit order are gas and oil $\mathrm{CPH}$ plants that are optimized based on heating requirements. Coal generation is on average cheaper than generation by gas, but depending on fuel and allowance prices, the merit order includes areas that contain both coal and gas generators. The most expensive plants are oil plants, and based on their marginal cost of generation, they would practically never be used other than in the context of heatoptimized CPH generation.

Generation from all energy sources is shown in Figure 6. Whereas the "must-run" technologies are actual production numbers, generation by coal, gas and oil is computed according to my merit order model, as no monthly generation is available for these fuel sources. 
The generation portfolio that is relevant for residual demand generates about a third of the total electricity, whereas the other two thirds are from to nuclear, lignite and renewable generation. The figure also shows that generation by renewables has increased over time, driving out fossil-based generation in the process (mostly gas), but also replacing some of the nuclear power, the output of which was discretely reduced after the accident at the Fukushima nuclear plant in March 2011.

Figure 6: Generation by energy source by month

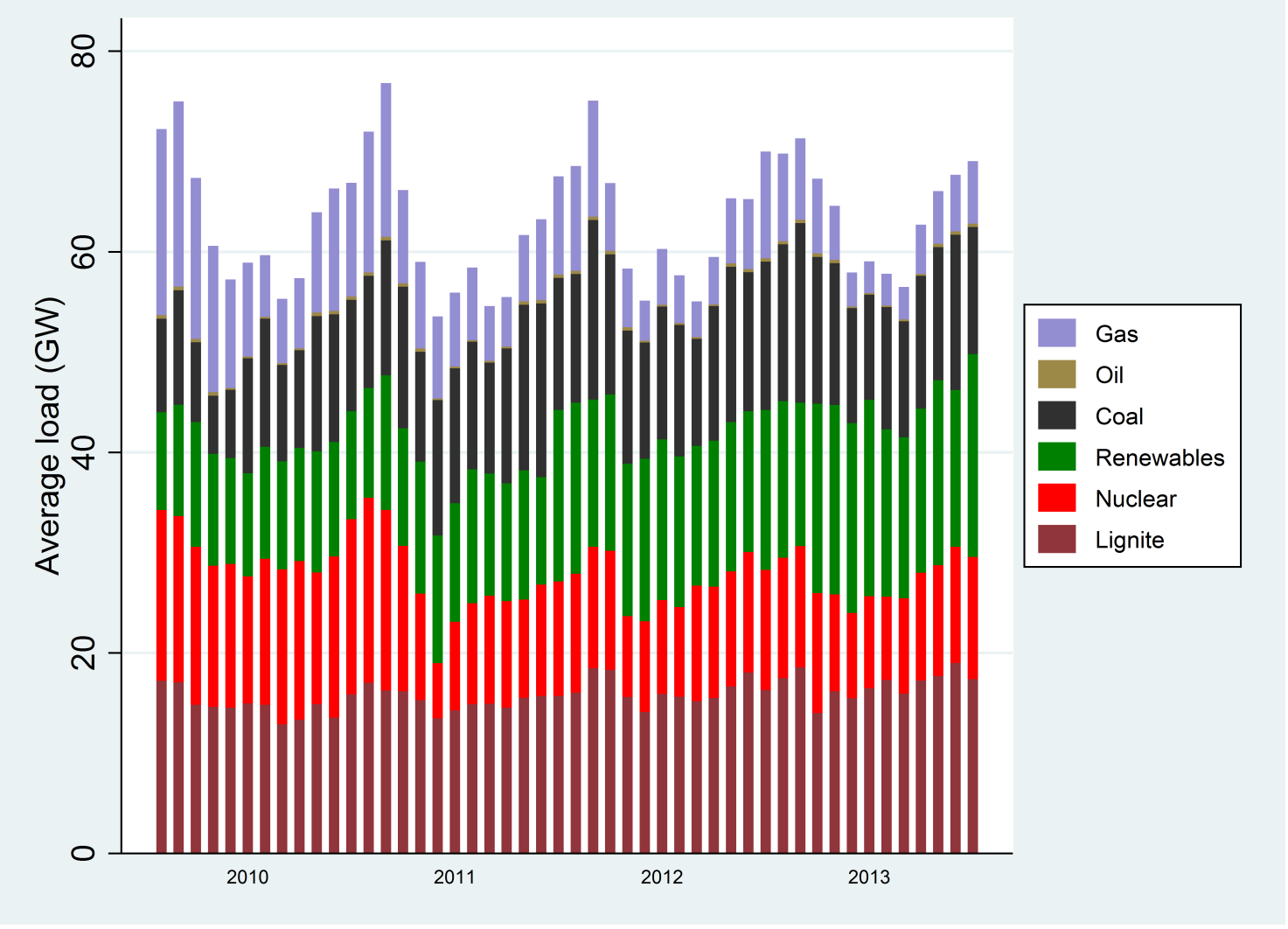

Source: ENTSO-E (lignite, nuclear and renewables) and own computations

\subsection{Robustness checks}

In the following, I discuss the sensitivity of the results with respect to some of the assumptions that underly the estimation of the production costs associated with MGU.

Adjustment of the generation portfolio. Since I do not observe the technology of the generators with a capacity between 10 and $100 \mathrm{MW}$ that I add to my portfolio, I assume the same technology distribution as for the larger generators. As a robustness check, I alternatively assume that all of the additional technology is of the most efficient available type (CCGT for 
gas, conventional for oil), or of the least efficient type (OCGT for both gas and oil). The average fuel and allowance cost of the MGU are practically identical to those in the base model. Likewise, the point estimates from the IV regressions are not sensitive to the technology choice for the additional capacity. This is most likely due to the fact that coal is marginal during most hours, whereas the capacity adjustment only pertains to gas and oil plants.

Computing heat rates. I compute heat rates based on data from the literature and a subset of plants in the dataset for which I was able to find information about the heat rate. The fuel and allowance costs of the MGU affect my point estimates inverse-proportionally. For example, if the true heat rates for all generators were 10 percent higher than the ones I compute, then the true marginal costs would increase by $10 \%$ as well, and the true coefficient estimates would be $(100 / 1.1=) 91 \%$ of the ones I compute here. However, because the computed heat rates closely match the subset of heat rates that are actually observed, a significant (average) deviation between true and computed heat rates is unlikely. Individual deviations are of course possible, but as long as these deviations are independent of input prices this should not result in biased coefficients.

$\mathrm{CPH}$ generation. In addition to the parameter that defines the portion of $\mathrm{CPH}$ generation that is operated based on heat requirements, the $\mathrm{CPH}$ adjustment also depends on the opportunity cost of process gas, because many process gas plants are used for heat generation. In my model, I use a proportionality factor of 0.94 and an opportunity cost for process gas that is $75 \%$ of the natural gas price per unit of energy, because this best matched reported monthly generation for 2013. As a robustness check, I re-computed the merit order based on an opportunity cost for process gas of only $25 \%$ of the gas price, which results in a heatoptimized share of $\mathrm{CPH}$ of $73 \%$. The average fuel and allowance cost of the MGU change from 29.31 and 7.26 (in euro/MWh) to 28.66 and 7.56, respectively. The results from the base regression using this amended generation portfolio are virtually unchanged.

Dynamic constraints. When identifying the MGU, I abstract from dynamic constraints faced by firms and implicitly assume that the firms' supply bids for hour $t$ is independent of their supply bids for hours $t-1$ and $t+1$. In reality, there are costs associated with changing a plant's output, starting production, and minimum downtime requirements. One might try to incorporate these costs, for example by increasing marginal costs for hour $t$ if a plant has not 
been running in hour $t-1$, or will not be running in $t+1$. However, there are different ways of doing this, and none seems more convincing than the other from a theoretical point of view. $^{26}$ Whereas it can be argued that my model is correct on average as it replicates annual generation reported on the monthly and annual level, it is likely that it misidentifies the MGU for many individual hours (which is the main reason for my IV approach, as discussed above). Figure 5 shows that the marginal cost curve is relatively flat over a large part of the merit order, such that misidentifying the MGU should not lead to a large error in terms of marginal input costs for medium loads. However, at hours with very low or very high demand levels, mis-identifying the MGU could result in a substantial measurement error, and if the mis-identification is not symmetric, then this would lead to biased estimates of pass-through during these hours. To assess the sensitivity of my results with respect to the identification of the MGU, I re-run my merit order model after varying residual demand by 2 GW during hours of low and high demand. ${ }^{27}$ As discussed below, the qualitative pattern of pass-through remains stable.

\section{Results}

I start by presenting the results from the marginal cost model, followed by those based on the price model. I present the second-stage results from the base model and some alternative specifications in the main text; the results from the corresponding first-stage and reducedform regressions are presented in Appendix A3.

\subsection{IV regressions based on marginal costs}

I estimate (6) based on a two-step generalized methods of moments (GMM) procedure that yields efficient coefficient estimates and consistent standard errors in the presence of arbitrary heteroskedasticity and autocorrelation. ${ }^{28}$ As excluded instruments for marginal fuel

\footnotetext{
${ }^{26}$ Based on a similar argument, Borenstein et al. (2002) also chose to ignore ramping costs in their model.

${ }^{27} \mathrm{I}$ allow for both a decrease and an increase in residual demand to allow for a range of strategic behavior. For example, firms may temporarily increase the capacity of inframarginal generators during hours of very high demand (which would shift the MGU to the right on the merit order curve), or restrict supply in order to drive up prices (shift to the left). Similarly, firms could take generators at the bottom of the merit order offline (by placing a very high bid) during hours of low demand or bid below marginal cost and thus decrease it.

${ }^{28}$ The model is estimated using Stata's ivreg2 command, implemented by Baum et al. (2010). I implemented the error correction using the Bartlett Kernel with automatic bandwidth selection proposed by Newey and West
} 
and allowance costs, I use prices for coal, natural gas and EUAs. In order to account for the nonlinear nature of the merit order and to obtain an over-identified model that allows for an orthogonality test for the EUA price, I further include the square of the natural gas price. ${ }^{29}$

The regression results from the second stage are shown in Table 3. The first column contains the results for the base model estimated for all hours combined, whereas the second column allows pass-through and the intercept to differ between peak and offpeak hours. The next two pairs of columns show equivalent results after including yearly and monthly dummies, and 168 week-hour dummies; for these regressions, the constant is equal to the omitted dummy category and thus suppressed. For the regressions that allow for differential pass-through during peak vs. offpeak hours, I additionally include interaction terms between the peak dummy and fuel prices as excluded instruments. ${ }^{30}$

The results indicate complete, or near-complete, pass-through of both fuel and allowance costs. Including time dummies affects the point estimates, but it also greatly increases the confidence intervals. Although time dummies are often used in the context of hourly and/or seasonal data, their inclusion may not be appropriate in the current context. In theory, they proxy for variation in demand and supply throughout the week and the year. However, this variation is already captured in the variation of marginal fuel and allowance costs. Adding a proxy in addition to marginal input costs reduces the explanatory power of the latter, because the coefficient estimates are based on the non-overlapping portion only.

All models are over-identified and thus allow for testing the corresponding over-identifying restrictions. Based on Hansen's J statistic, the joint null hypothesis that the instruments are uncorrelated with the error term and that the endogenous regressors are correctly excluded, cannot be rejected. I further carry out an orthogonality test for the allowance price, which results in a C-statistic. ${ }^{31}$ Again, the null hypothesis of exogeneity cannot be rejected. Because (1994), which resulted in a selection of 74 lags for all regressions.

${ }^{29}$ One could also include the oil price as an additional instrument. However, because (i) the coefficient estimates are very similar to those from the model without the oil price, (ii) the orthogonality test for the oil price failed in some instances, and (iii) my dispatch model indicates that oil is practically never on the margin, I did not include the oil price in the IV regressions presented here.

${ }^{30}$ Because including all interaction terms results in multicollinearity (since all input prices multiplied with the peak hour dummy are zero during offpeak hours), I focus on combinations of interaction terms that (i) pass the test for over-identification of all instruments and (ii) result in an over-identified model even when removing the allowance price. Among the remaining possibilities, I choose the combination that yields the best explanatory power of the instruments as indicated by the Kleibergen-Paap Wald statistic. The set of instruments employed per regression can be seen in the first-stage results in Appendix A3.

${ }^{31}$ The Hansen J-statistic is a GMM-version of the Sargan-Hansen statistic used in the context of 2SLS. Under the null, the test statistic is distributed chi-squared in the number of over-identifying restrictions, which is the 
Table 3: Pass-through during all hours combined, and during peak vs. offpeak hours

\begin{tabular}{|c|c|c|c|c|c|c|c|c|}
\hline & \multicolumn{2}{|c|}{ Base model } & \multicolumn{2}{|c|}{ Y/M dummies } & \multicolumn{2}{|c|}{ Y/M/W-H dum. } & \multicolumn{2}{|c|}{ No EUA } \\
\hline & All hours & Peak/offp. & All hours & Peak/offp. & All hours & Peak/offp. & All hours & Peak/offp. \\
\hline Fuel cost & $\begin{array}{l}0.927^{* * *} \\
(0.0526)\end{array}$ & $\begin{array}{l}0.943^{* * *} \\
(0.0519)\end{array}$ & $\begin{array}{c}1.102^{* * *} \\
(0.133)\end{array}$ & $\begin{array}{c}1.127^{* * *} \\
(0.137)\end{array}$ & $\begin{array}{c}1.102^{* * *} \\
(0.129)\end{array}$ & $\begin{array}{c}1.040^{* * *} \\
(0.143)\end{array}$ & $\begin{array}{l}0.926^{* * *} \\
(0.0531)\end{array}$ & $\begin{array}{l}0.943^{* * *} \\
(0.0526)\end{array}$ \\
\hline FC*peak & & $\begin{array}{c}-0.0364 \\
(0.0622)\end{array}$ & & $\begin{array}{l}-0.0726 \\
(0.0642)\end{array}$ & & $\begin{array}{c}0.182^{* *} \\
(0.0630)\end{array}$ & & $\begin{array}{c}-0.0388 \\
(0.0627)\end{array}$ \\
\hline Allow. cost & $\begin{array}{l}0.962^{* * *} \\
(0.0753)\end{array}$ & $\begin{array}{l}0.866^{* * *} \\
(0.0782)\end{array}$ & $\begin{array}{c}0.943^{* * *} \\
(0.234)\end{array}$ & $\begin{array}{l}0.785^{* *} \\
(0.257)\end{array}$ & $\begin{array}{c}0.936^{* * *} \\
(0.228)\end{array}$ & $\begin{array}{c}0.849^{* * *} \\
(0.256)\end{array}$ & $\begin{array}{l}0.922^{* * *} \\
(0.0951)\end{array}$ & $\begin{array}{l}0.829^{* * *} \\
(0.0977)\end{array}$ \\
\hline AC*peak & & $\begin{array}{l}0.252^{*} \\
(0.111)\end{array}$ & & $\begin{array}{l}0.366^{* *} \\
(0.130)\end{array}$ & & $\begin{array}{c}0.244 \\
(0.144)\end{array}$ & & $\begin{array}{c}0.255^{*} \\
(0.112)\end{array}$ \\
\hline Peak & & $\begin{array}{l}6.947^{* *} \\
(2.242)\end{array}$ & & $\begin{array}{l}6.395^{* *} \\
(2.219)\end{array}$ & & & & $\begin{array}{l}6.992^{* *} \\
(2.250)\end{array}$ \\
\hline Const. & $\begin{array}{c}9.817^{* * *} \\
(1.654)\end{array}$ & $\begin{array}{c}7.367^{* * *} \\
(1.482)\end{array}$ & & & & & $\begin{array}{c}10.16^{* * *} \\
(1.749)\end{array}$ & $\begin{array}{c}7.681^{* * *} \\
(1.586)\end{array}$ \\
\hline Endog. & 2 & 4 & 2 & 4 & 2 & 4 & 2 & 4 \\
\hline Excl. instr. & 4 & 6 & 4 & 6 & 4 & 6 & 3 & 5 \\
\hline J-Statistic & 3.791 & 4.183 & 1.368 & 1.422 & 0.915 & 0.909 & 3.328 & 3.769 \\
\hline J-Stat., p & 0.150 & 0.124 & 0.505 & 0.491 & 0.633 & 0.635 & 0.0681 & 0.0522 \\
\hline C-Stat. & 0.433 & 0.379 & 1.329 & 1.328 & 0.776 & 0.790 & . & . \\
\hline C-Stat., $\mathrm{p}$ & 0.511 & 0.538 & 0.249 & 0.249 & 0.378 & 0.374 & ${ }^{\circ}$ & . \\
\hline Rsq & 0.302 & 0.349 & 0.282 & 0.323 & 0.449 & 0.451 & 0.302 & 0.350 \\
\hline
\end{tabular}

Note: $\mathrm{N}=35,064$ for all regressions. Standard errors in parentheses, corrected for autocorrelation and heteroskedasticity. All regressions additionally include dummies for hours of negative residual demand, and for hours where CPH plants are marginal. Significance levels: ${ }^{*} p<0.05,{ }^{* *} p<0.01,{ }^{* * *} p<0.001$

these tests are inconclusive in the sense that they are only valid conditional on the other instruments satisfying the exclusion restriction, I also estimate a model where I drop the allowance price as an instrument (last two columns in Table 3). The results are very similar to those from the base model. ${ }^{32}$

The level of cost pass-through varies between peak and offpeak hours. This is especially true for allowance costs, where the interaction with the peak dummy is significant in three out of four model specifications, whereas only the model including hourly dummies provides an indication for differential pass-through of fuel costs. In order to further investigate the issue of varying levels of cost pass-through, I re-estimate the base model separately for all 168 number of excluded instruments minus the number of endogenous regressors. The C-statistic is a test of a subset of the orthogonality conditions, in this case the one corresponding to the EUA price. The null hypothesis of orthogonality is not rejected if the C-statistic and both J-statistics (from the full model and the model that excludes the suspect instrument) are small.

${ }^{32}$ This may seem surprising, given that the allowance prices is a necessary proxy for allowance costs. However, since coal and gas prices are known determinants of the allowance price, they account for a significant part of the variation in allowance prices. 
Figure 7: Pass-through of fuel and allowance costs by week-hour

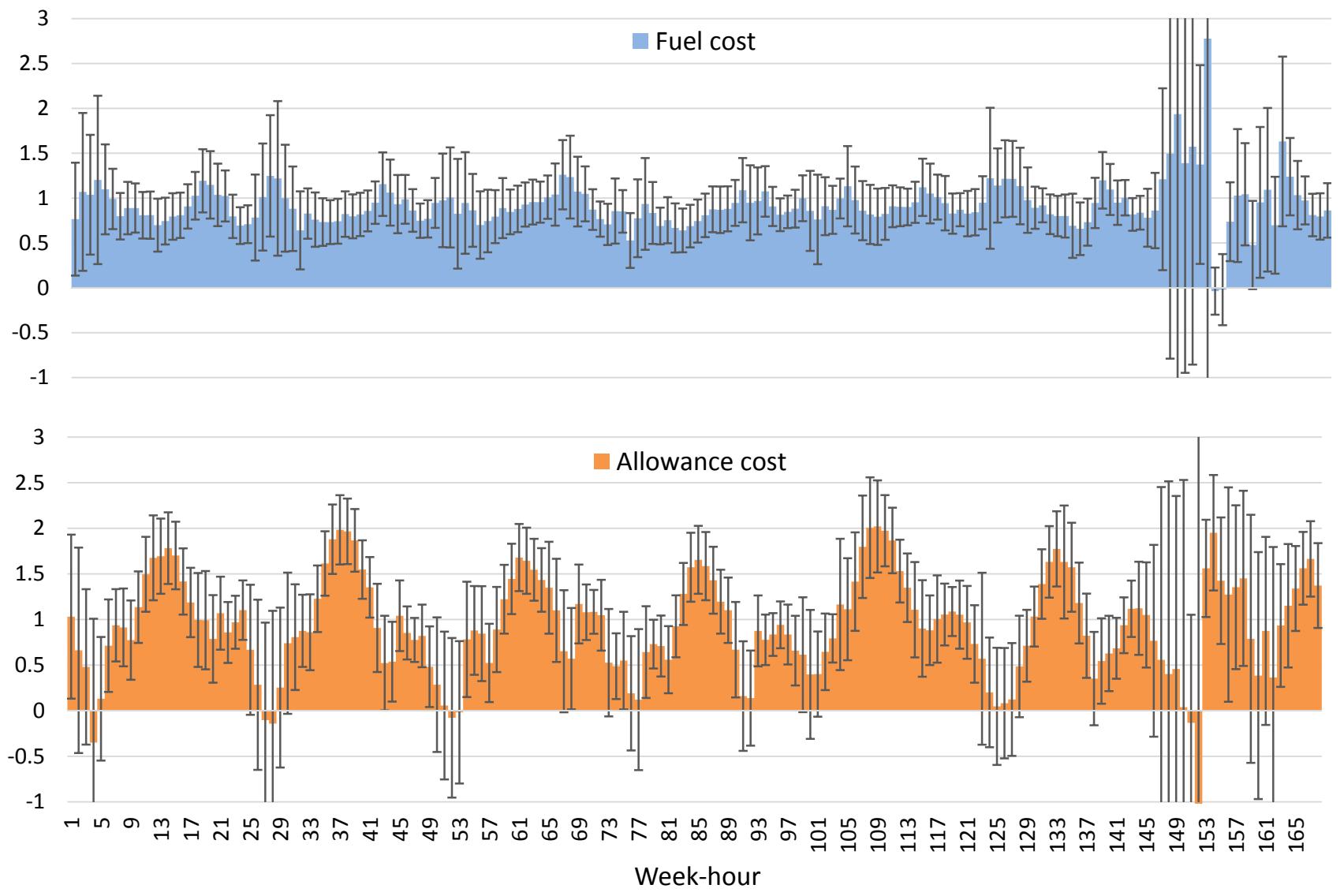

Note: Hour 1 starts at midnight on Monday, and hour 168 starts at 11 p.m. on Sunday

hours of the week. The coefficient estimates, along with 95-\% standard intervals, are shown in Figure 7. The point estimates for pass-through indicate that pass-through of allowance costs varies significantly throughout the load curve, whereas fuel costs are passed through more evenly. However, the standard errors are quite large.

To increase the precision of these estimates while at the same time using load period differentiations that are less broad than the generic peak/offpeak load periods, I separate the week into periods of very low demand (from 11 p.m. to 5 a.m.), very high demand (from 10 a.m. to 4 p.m. on workdays), and medium demand (all remaining hours). The coefficient estimates are presented in Table 4. The results indicate highly variable allowance cost pass-through of allowance costs, which exceeds unity during periods of high demand.

The estimates of cost pass-through are visualized in Figure 8. The leftmost cluster shows pass-through for all hours combined, whereas the remaining clusters refer to a subset of hours. The black bars correspond to $95-\%$ confidence intervals. The figure shows that fuel costs are passed through relatively evenly and (near) completely throughout the week. How- 
Table 4: Pass-through during hours with very low and very high demand

\begin{tabular}{|c|c|c|c|c|}
\hline & Base model & Y/M dummies & P/M/W-H dum. & No EUA \\
\hline Fuel cost & $\begin{array}{l}0.974^{* * *} \\
(0.0575)\end{array}$ & $\begin{array}{c}1.148^{* * *} \\
(0.133)\end{array}$ & $\begin{array}{c}1.152^{* * *} \\
(0.130)\end{array}$ & $\begin{array}{l}0.974^{* * *} \\
(0.0581)\end{array}$ \\
\hline FC*Low & $\begin{array}{r}-0.00895 \\
(0.0497)\end{array}$ & $\begin{array}{c}0.0345 \\
(0.0630)\end{array}$ & $\begin{array}{c}0.0180 \\
(0.0578)\end{array}$ & $\begin{array}{r}-0.00527 \\
(0.0499)\end{array}$ \\
\hline FC*High & $\begin{array}{l}-0.149^{* *} \\
(0.0509)\end{array}$ & $\begin{array}{l}-0.178^{* *} \\
(0.0577)\end{array}$ & $\begin{array}{c}-0.181^{* * *} \\
(0.0534)\end{array}$ & $\begin{array}{l}-0.155^{* *} \\
(0.0514)\end{array}$ \\
\hline Allow. cost & $\begin{array}{l}0.810^{* * *} \\
(0.0864)\end{array}$ & $\begin{array}{c}0.775^{* * *} \\
(0.233)\end{array}$ & $\begin{array}{c}0.765^{* * *} \\
(0.229)\end{array}$ & $\begin{array}{c}0.768^{* * *} \\
(0.105)\end{array}$ \\
\hline$A C *$ Low & $\begin{array}{l}-0.0887 \\
(0.0975)\end{array}$ & $\begin{array}{c}-0.204 \\
(0.147)\end{array}$ & $\begin{array}{c}-0.176 \\
(0.145)\end{array}$ & $\begin{array}{c}-0.0916 \\
(0.0979)\end{array}$ \\
\hline AC*High & $\begin{array}{c}0.810^{* * *} \\
(0.113)\end{array}$ & $\begin{array}{c}0.903^{* * *} \\
(0.140)\end{array}$ & $\begin{array}{c}0.890^{* * *} \\
(0.136)\end{array}$ & $\begin{array}{c}0.812^{* * *} \\
(0.113)\end{array}$ \\
\hline Low & $\begin{array}{c}-5.163^{* * *} \\
(1.463)\end{array}$ & $\begin{array}{c}-4.849^{* *} \\
(1.530)\end{array}$ & & $\begin{array}{c}-5.239^{* * *} \\
(1.466)\end{array}$ \\
\hline High & $\begin{array}{c}3.849 \\
(2.073)\end{array}$ & $\begin{array}{c}3.449 \\
(2.109)\end{array}$ & & $\begin{array}{c}4.040 \\
(2.090)\end{array}$ \\
\hline Const. & $\begin{array}{c}10.18^{* * *} \\
(1.820) \\
\end{array}$ & & & $\begin{array}{c}10.54^{* * *} \\
(1.910)\end{array}$ \\
\hline Endog. & 6 & 6 & 6 & 6 \\
\hline Excl. instr. & 8 & 8 & 8 & 7 \\
\hline J-Statistic & 4.154 & 0.975 & 1.378 & 3.643 \\
\hline J-Stat., p & 0.125 & 0.614 & 0.502 & 0.0563 \\
\hline C-Stat. & 0.482 & 0.900 & 1.342 & - \\
\hline C-Stat., p & 0.487 & 0.343 & 0.247 & . \\
\hline Rsq & 0.353 & 0.321 & 0.444 & 0.354 \\
\hline
\end{tabular}

Note: $\mathrm{N}=35,064$ for all regressions. Standard errors in parentheses, corrected for autocorrelation and heteroskedasticity. All regressions additionally include dummies for hours of negative residual demand, and for hours where $\mathrm{CPH}$ plants are marginal. Significance levels: ${ }^{*} p<0.05,{ }^{* *} p<0.01,{ }^{* * *} p<0.001$

ever, pass-through of allowance costs vary across the load curve. During hours of high demand, allowance costs are passed through more than completely, and the hypothesis of equal pass-through of fuel and allowance costs is clearly rejected. In contrast, allowance costs are passed through less than completely during hours of low demand, and this is statistically significant for the models without time dummies.

The reason for heterogeneity in cost pass-through with respect to input type is not obvious, since in principle firms should not care about the composition of their costs when deciding about the degree of pass-through. However, the results are robust across model specifications. As an additional robustness check, I re-estimate the regressions after shifting residual demand by $+/-2$ GW during hours of very low and very high demand, as discussed in section 3.4 
Figure 8: Cost pass-through of fuel and allowance costs by load period

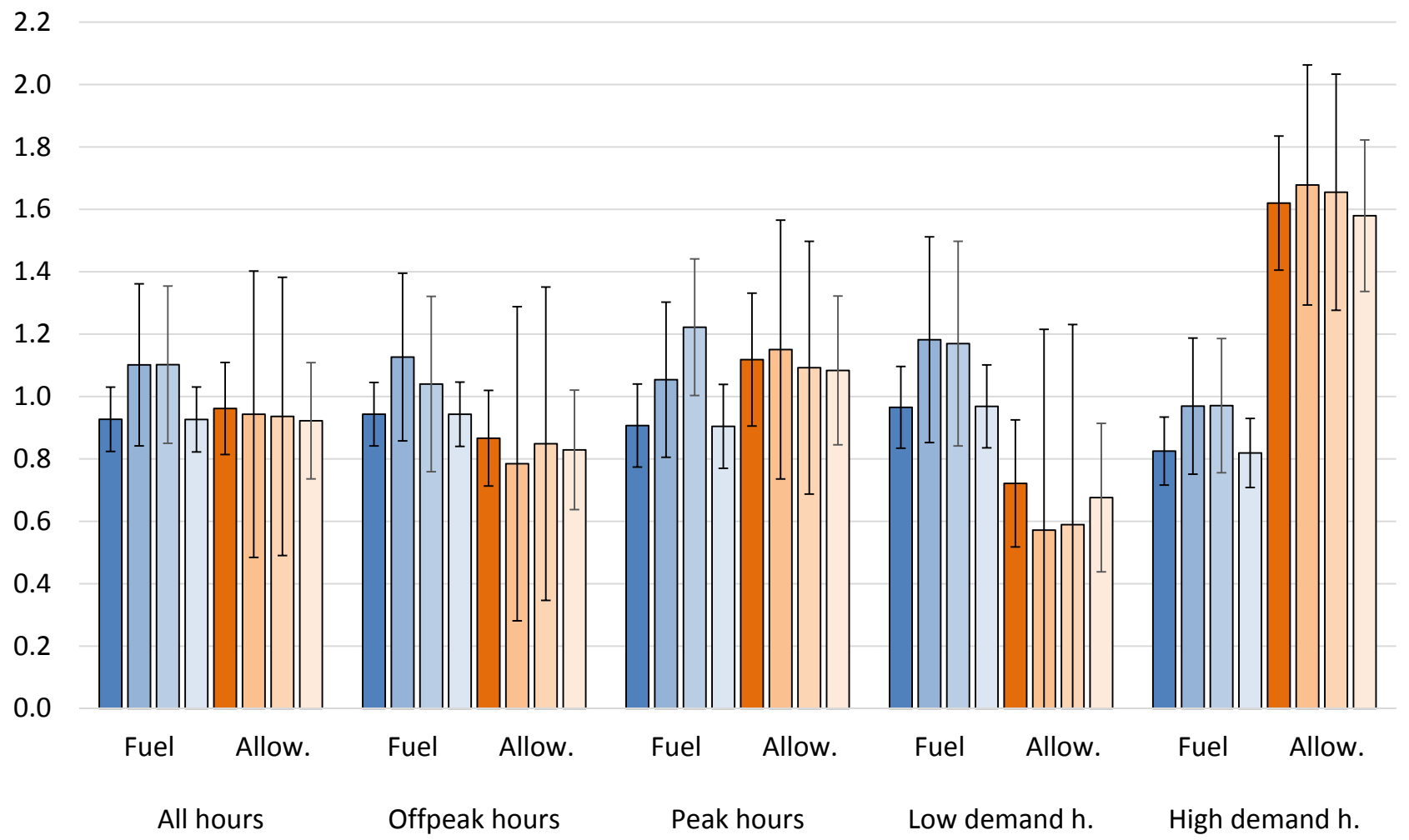

Note: Low demand marks the hours between 11 p.m and 5 a.m., and high demand the hours between 10 a.m. and 4 p.m. during weekdays. The four results per input and load period correspond to the four models presented in Tables 3-4.

(the results are presented in Figure A1 the Appendix). The pattern of the results from the base model remains stable for high demand-hours in the sense that allowance cost passthrough exceeds 100\%. For hours of low demand, adding $2 \mathrm{GW}$ to residual demand increases allowance cost pass-through, such that the confidence interval includes $100 \%$.

A possible explanation for differential cost pass-through are long-term contracts for fuel. Although surplus fuel can in theory be sold on the market, this entails a transactions cost that is likely to be much larger than the transaction cost associated with buying or selling allowances (which is virtually nil). Note also that storing fuel is very costly, whereas emission allowances are electronic entries in a firm's operator holding account. Next, that allowance costs are passed through to a greater extent during periods of high demand could be that during these hours, firms are not constrained by dynamic considerations (an explanation also proposed by Fabra and Reguant, 2014). In contrast, firms may bid below marginal cost during periods of low demand in order not to have to shut down a plant for a few hours. This would also explain why the difference in pass-through between fuel and allowance costs only 
appears during hours of high demand.

Finally, the result that allowance costs are passed through more than fully during periods of very high demand could be an indication that the shape of the demand curve varies across the load curve. With sufficiently inelastic and curved demand, pass-through of input costs can be more than complete as discussed in the context of Figure 1.

Figure 9: Intercepts and residual demand by year, month and week-hour

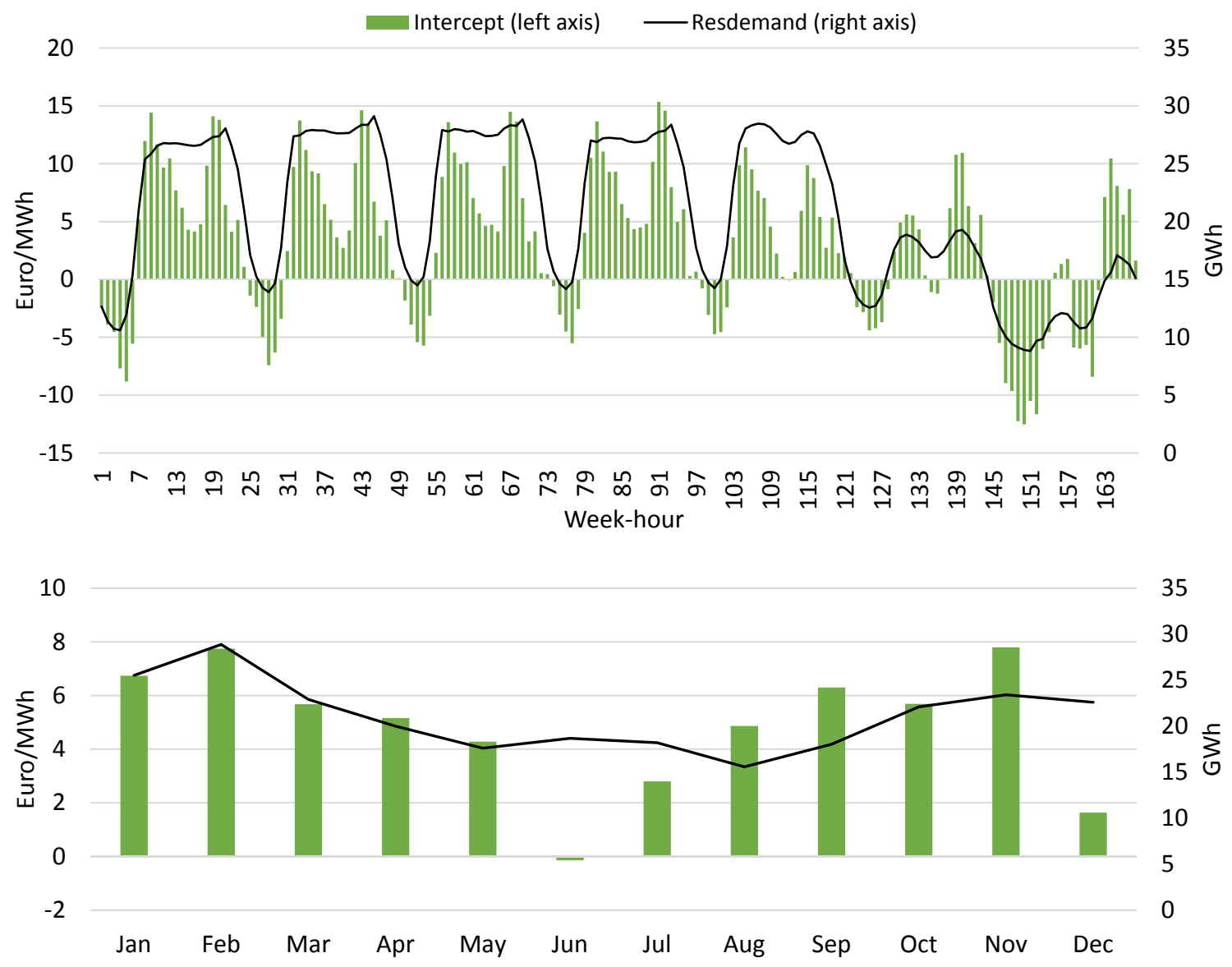

The result of on average complete (or near complete) pass-through of allowance costs thus masks the presence of interchanging periods of incomplete and more than complete pass-through, which has different implications for the competitiveness of the electricity market than a result of constant and complete cost pass-through. The bars in Figure 9 shows the coefficients on the monthly and week-hourly dummies, which were suppressed in Table 4. These intercepts represent the so-called "green spread", i.e. the price of electricity net of the cost for fuel and emissions. With strict marginal cost pricing and no ramping costs, the green spread would be expected to be constant as it recovers costs from labor and capital that are fixed in the short run. The strong variation of the spread within the week and the year sug- 
gests the presence of a markup and/or of costs associated with startup and ramping. Given the available data, it is not possible to separately identify the markup, but the striking correlation with residual demand (black line) suggests the presence of a time-varying markup. Note also that during some hours, the spread is negative, indicating that firms are willing to bid below costs in order to avoid shutting their generators down.

\subsection{Price regressions}

To compare my results with purely price-based approaches, I regress electricity prices on input prices (i.e., I use the OLS estimator on input prices rather than the IV estimator on marginal cost). To control for contemporaneous shocks in demand and supply, I include hourly generation by solar and wind, as well as heating and cooling degree days based on the daily average temperature in the 11 largest German cities. ${ }^{33}$ To identify cost pass-through, I use a heat rate for the average marginal coal and oil generators of 2.63 (in MWh fuel input per MWh electric output) and of 2.0 for the average marginal gas generator, ${ }^{34}$ and an emission factor of 0.341 (in $\mathrm{tCO}_{2}$ per MWh fuel) for coal and 0.202 for natural gas.

Table 5: Cost pass-through based on price regressions

\begin{tabular}{lccccc|ccccc}
\hline \hline & \multicolumn{9}{c|}{ Base model } & \multicolumn{4}{c}{ Including Y., M. and H. dummies } \\
& All hours & Offp. & Peak & Low d. & High d. & All hours & Offp. & Peak & Low d. & High d. \\
\hline Imputed pass-through & & & & & & & & & \\
$\alpha_{\mathrm{F}}$ & 0.8783 & 0.8331 & 1.0194 & 0.8261 & 0.8898 & 0.6549 & 0.6083 & 0.7362 & 0.5791 & 0.6422 \\
st.dev & 0.083 & 0.082 & 0.095 & 0.070 & 0.090 & 0.145 & 0.144 & 0.138 & 0.144 & 0.155 \\
$\mathrm{p}\left(\alpha_{\mathrm{F}}=1\right)$ & 0.145 & 0.041 & 0.839 & 0.013 & 0.220 & 0.017 & 0.007 & 0.056 & 0.004 & 0.021 \\
$\alpha_{\mathrm{A}}$ & 1.5702 & 1.3550 & 1.3555 & 0.9216 & 1.8010 & 1.0699 & 0.9987 & 1.1745 & 0.7320 & 1.5874 \\
st.dev & 0.319 & 0.313 & 0.316 & 0.239 & 0.399 & 0.310 & 0.288 & 0.320 & 0.241 & 0.499 \\
$\mathrm{p}\left(\alpha_{\mathrm{A}}=1\right)$ & 0.074 & 0.257 & 0.261 & 0.743 & 0.045 & 0.822 & 0.997 & 0.585 & 0.267 & 0.239 \\
$\mathrm{p}\left(\alpha_{\mathrm{F}}=\alpha_{\mathrm{A}}\right)$ & 0.064 & 0.156 & 0.366 & 0.738 & 0.046 & 0.325 & 0.326 & 0.294 & 0.663 & 0.126 \\
\hline Imputed marginal generation shares (point estimates) & & & & & & \\
Coal & $58 \%$ & $61 \%$ & $54 \%$ & $81 \%$ & $41 \%$ & $80 \%$ & $91 \%$ & $65 \%$ & $116 \%$ & $55 \%$ \\
Natural gas & $42 \%$ & $39 \%$ & $46 \%$ & $19 \%$ & $59 \%$ & $20 \%$ & $9 \%$ & $35 \%$ & $-16 \%$ & $45 \%$ \\
\hline Marginal generation shares based on dispatch model & & & & & & \\
Coal & $75 \%$ & $79 \%$ & $67 \%$ & $84 \%$ & $63 \%$ & $75 \%$ & $79 \%$ & $67 \%$ & $84 \%$ & $63 \%$ \\
Natural gas & $25 \%$ & $21 \%$ & $32 \%$ & $15 \%$ & $36 \%$ & $25 \%$ & $21 \%$ & $32 \%$ & $15 \%$ & $36 \%$ \\
Oil & $0.3 \%$ & $0.3 \%$ & $0.3 \%$ & $0.3 \%$ & $0.4 \%$ & $0.3 \%$ & $0.3 \%$ & $0.3 \%$ & $0.3 \%$ & $0.4 \%$ \\
\hline \hline
\end{tabular}

Note: Standard errors computed using Delta method.

\footnotetext{
${ }^{33}$ Specifically, I define heating and cooling degree days (in degree Celsius) as $\mathrm{HDD}=18$-temp if temp $<18$; $\mathrm{HDD}=0$ otherwise, and $\mathrm{CDD}=$ temp -22 if temp $>22$; $\mathrm{CDD}=0$ otherwise.

${ }^{34}$ These are generic heat rates used for the computation of dark and spark spreads and correspond to an efficiency of $38 \%$ and $50 \%$ (in MWh electric output per MWh fuel input), respectively. I exclude the oil price because oil is practically never the price-setting technology.
} 
The results for imputed pass-through from the price regressions are shown in Table 5; the full results from the price regression are presented in Appendix A3. The left panel refers to the base model, and the right panel contains the results from a model that additionally includes yearly, monthly and week-hourly dummies. The rates of pass-through are visualized in Figure 10. The null hypothesis of complete and equal pass-through cannot be rejected, but this is mainly due to the large confidence intervals. The point estimates for cost pass-through differ from those from the marginal cost model.

Figure 10: Cost pass-through based on price model

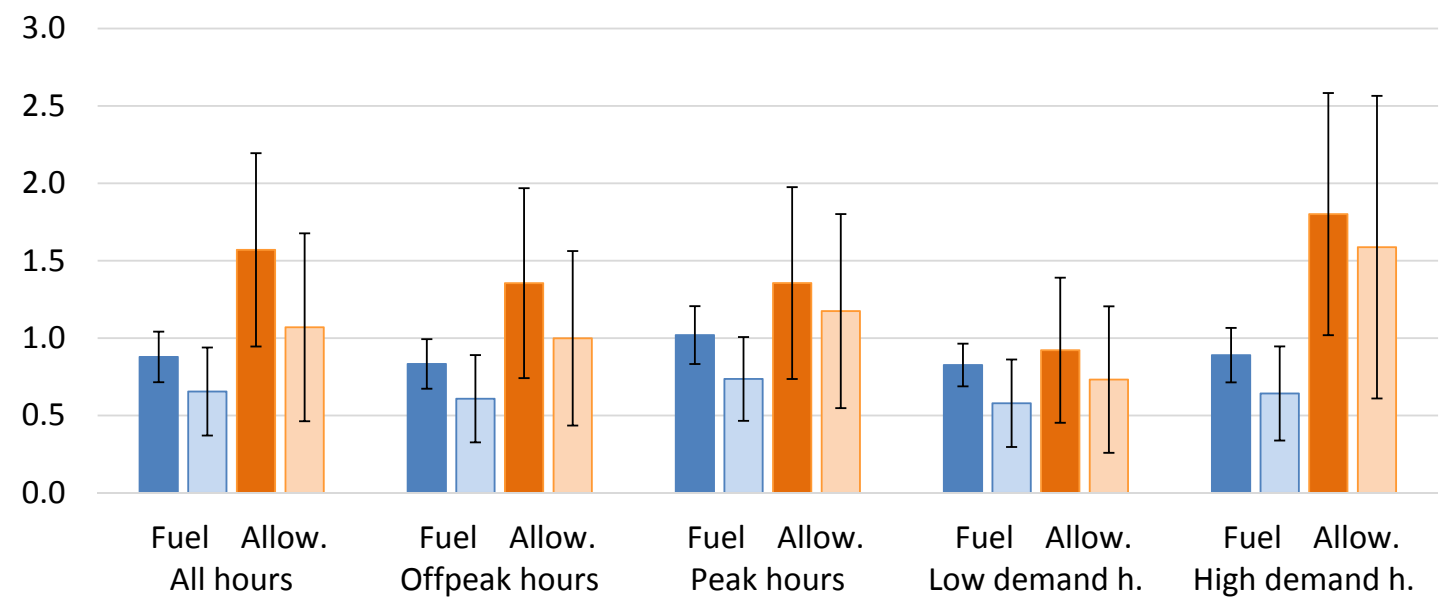

Note: The left bar for each input and load period corresponds to the base model, and the right bar to the model that includes yearly, monthly and hourly dummies, respectively.

The imputed marginal generation shares (the $T_{F} / T$ in (9)) differ widely from the ones computed with the merit order model. In general, the price model predicts gas to be on the margin much more frequently than coal, due to the high correlation between gas and electricity prices. This results in a lower carbon intensity of the average MGU (captured by the summation term in (10)), and translates to a higher rate of allowance pass-through.

The difference between the results from the models based on marginal input costs, and those based on input prices can in principle be due to three reasons: (i) The inclusion of generation by renewables and temperature to control for demand and supply shocks is less complete than the approach via residual demand, which includes all shocks to demand and supply. In other words, the residual demand for fossil electricity is not identified, which leads to biased estimates due to unobserved heterogeneity. (ii) As discussed in section 2, the pricebased approach requires an exogeneity assumption between fuel prices and the nature of the marginal generator; since the merit order generally depends on fuel prices, this assumption 
most likely does not hold. (iii) It is possible that the exclusion restriction in the marginal costbased model is not satisfied, despite the tests for over-identification. No similar restriction is required for the price regressions, which are based on OLS.

\section{Conclusions}

I estimate the rate of pass-through for fuel and allowance costs in the German wholesale electricity market in the short run using hourly spot market data. By constructing a detailed supply curve of fossil-based electricity and intersecting it with the residual demand for fossilbased generation, I determine the marginal generating unit for every hour of the year, which allows me to identify cost pass-through directly via the generation costs of the MGU. In order to address issues related to endogeneity and measurement error, I estimate the coefficients on fuel and allowance costs using an instrumental variable framework.

I find that allowance costs are passed through (near) completely to hourly wholesale electricity prices on average. When focusing on pass-through during different parts of the load curve, I find that allowance cost pass-through is lower during hours of low demand and higher during hours of high demand, and that pass-through of allowance costs varies by much more than pass-through of fuel costs. Both results are consistent with those reported by Fabra and Reguant (2014) in the context of the Spanish electricity market. Possible reasons for this pattern of cost pass-through are dynamic constraints in the sense that firms are willing to bid below marginal cost when demand is very low in order to avoid shutting down a generator, and differences in transactions costs between fuel and allowance inputs. The finding of more than complete pass-through of allowance costs during periods of high demand could be due to very inelastic and nonlinear demand during these hours. However, the possibility of biased estimates can never be fully excluded in an IV regression approach, because the exclusion restriction cannot be tested directly.

Whereas complete pass-through would be consistent, or at least not inconsistent, with perfect competition in the electricity market, the variation of pass-through and of electricity spreads over the load curve suggest that firms do behave strategically. Given the data, I cannot identify the markup separately from ramping and startup costs, but the almost perfect correlation between spreads and residual demand for fossil electricity suggest that the inter- 
cept includes a time-varying markup, which implies the exercise of market power at least during some hours.

The similarity of my results to those by Fabra and Reguant (2014) suggests that it is possible to identify the marginal generator even in the absence of firm-level bid data. To more directly test the equivalence of the two approaches, a dispatch order-based approach could be carried out in the context of the Spanish market, which I leave for future research. Furthermore, I show that estimating cost pass-through based on input prices rather than marginal input costs, as has been the standard procedure in the literature, leads to much less precise estimates, and likely to bias due to the endogeneity of heat rates and input prices.

For the purpose of determining the incidence of carbon policy, however, what matters is the rate of average cost pass-through. For all hours combined, pass-through of allowance costs from the base model is in the range of $81 \%-111 \%$. Combining cost pass-through with a generous free allocation of allowances implies that the profits of electricity firms were an increasing function of the allowance price (Hintermann, 2011). With complete cost passthrough, the entire free allocation constitutes a windfall to firms. To put this into perspective, consider the free allocation to the largest ten electricity firms in the EU. Combined, these firms received around 1.7 billion free allowances for Phase I, and another 2.6 billion for Phase II (Hintermann, 2015). Using annual average allowance prices and assuming full cost pass-through, the value of this free allocation amounted to 72 billion euro during the first eight years of the EU ETS.

Considering that the incidence of climate policy falls predominantly (and perhaps even exclusively) on consumers, auctioning the allowances and using the revenue to lower preexisting taxes is preferable on normative grounds. My results thus validate the EU's decision to eliminate free allocation for Phase III for electricity producers in the EU-15. They also have implications for free allocation in other cap-and-trade system around the world. 


\section{References}

Aatola, Piia, Markku Ollikainen, and Anne Toppinen (2013) "Price determination in the EU ETS market: Theory and econometric analysis with market fundamentals," Energy Economics, Vol. 36, pp. 380-395.

Baum, C. F., M. E. Schaffer, and S. Stillman (2010) "ivreg2: Stata module for extended instrumental variables/2SLS, GMM and AC/HAC, LIML and k-class regression." http://ideas.repec.org/c/boc/bocode/s425401.html.

Borenstein, Severin, James B. Bushnell, and Frank A. Wolak (2002) "Measuring market inefficiencies in California's restructured wholesale electricity market," American Economic Review, Vol. 92, No. 5, pp. 1376-1405.

Bovenberg, A. Lans and Lawrence H. Goulder (1996) "Optimal environmental taxation in the presence of other taxes: General equilibrium analyses," American Economic Review, Vol. 86, No. 4, pp. 985-1006.

Burstein, Ariel and Gita Gopinath (2014) "International Prices and Exchange Rates," Handbook of International Economics, Vol. 4, pp. 391-451.

Chernyavs' ka, Liliya and Francesco Gulli (2008) "Marginal $\mathrm{CO}_{2}$ cost pass-through under imperfect competition in power markets," Ecological Economics, Vol. 68, No. 1, pp. 408421.

Ellerman, Denny, Claudio Marcantonini, and Aleksandar Zaklan (2016) "The EU ETS: Ten years and counting," Review of Environmental Economics and Policy, Vol. 10, No. 1, pp. 89-107.

Eurelectric (2012) "Power statistics and trends 2012." Union of the electricity industry.

Fabra, Natalia and Mar Reguant (2014) "Pass-through of Emissions Costs in Electricity Markets," American Economic Review, Vol. 104, No. 9, pp. 2872-2899.

Fell, Harrison (2010) “EU-ETS and Nordic Electricity," Energy Journal, Vol. 31, No. 2, pp. $1-26$. 
Fell, Harrison, Beat Hintermann, and Herman RJ Vollebergh (2015) "Carbon Content of Electricity Futures in Phase II of the EU ETS," The Energy Journal, Vol. 36, No. 4, pp. 61-83.

Fezzi, Carlo and Derek W. Bunn (2010) "Structural Interactions of European Carbon Trading and Energy Prices," Journal of Energy Markets, Vol. 2, No. 4, pp. 53-69.

Folke, C. (2000) "Minderung der Kohlendioxidemissionen durch Erneuerung vorhandener Kohlekraftwerke in der EU und dadurch verursachte Kosten,"Technical Report Band 439, Verein Deutscher Ingenieure (VDI).

Greene, William H. (2002) Econometric Analysis: Prentice Hall, 5th edition.

Grubb, Michael and Karsten Neuhoff (2006) "Allocation and competitiveness in the EU emissions trading scheme: Policy overview," Climate Policy, Vol. 6, No. 1, pp. 7-30.

Hepburn, Cameron, Michael Grubb, Karsten Neuhoff, Felix Matthes, and Maximilien Tse (2006) "Auctioning of EU ETS Phase II allowances: How and why?" Climate Policy, Vol. 6, No. 1, pp. 137-160.

Hintermann, Beat (2010) "Allowance Price Drivers in the First Phase of the EU ETS," Journal of Environmental Economics and Management, Vol. 59, No. 1, pp. 43 - 56.

(2011) "Market Power, Permit Allocation and Efficiency in Emission Permit Markets," Environmental and Resource Economics, Vol. 49, No. 3, pp. 327-349.

(2015) "Market power in emission permit markets: Theory and evidence from the EU ETS," Environmental and Resource Economics, pp. 1-24.

Hintermann, Beat, Sonja Peterson, and Wilfried Rickels (2016) "Price and market behavior in Phase II of the EU ETS," Review of Environmental Economics and Policy, Vol. 10, No. 1, pp. 108-128.

Hirth, Lion (2013) "The market value of variable renewables: The effect of solar wind power variability on their relative price," Energy economics, Vol. 38, pp. 218-236.

Honkatukia, Juha, Ville Malkonen, and Adriaan Perrels (2013) "Impacts of the European Emissions Trading Scheme on Finnish Wholesale Electricity Prices," in Francesco Gulli ed. Markets for Carbon and Power Pricing in Europe, Cheltenham, UK: Edward Elgar Publishing. 
Hoster, F. (1996) "Auswirkungen des europ aischen Binnenmarkts f ur Energie auf die deutsche Elektrizit atswirtschaft,"Technical Report Band 49, Werkstattreihe Oko-Institut.

IPCC (2006) "Chapter2: Stationary combustion," in Miwa K. Ngara T. Eggleston H.S., Buendia L. and Tanabe K. eds. 2006 IPPC Guidelines for National Greenhouse Gas Inventories, Vol. 2: Energy: IGES, Japan.

Leuthold, Florian U, Hannes Weigt, and Christian von Hirschhausen (2012) "A large-scale spatial optimization model of the European electricity market," Networks and spatial economics, Vol. 12, No. 1, pp. 75-107.

Linn, Joshua, Lucija Muehlenbachs, and Yushuang Wang (2014) "How do natural gas prices affect electricity consumers and the environment?" Resources for the Future Discussion Paper, No. 14-19.

Lo Prete, Chiara and Catherine S. Norman (2013) "Rockets and feathers in power futures markets? Evidence from the second phase of the EU ETS," Energy Economics, Vol. 36, pp. $312-321$.

Lutz, Benjamin Johannes, Uta Pigorsch, and Waldemar Rotfuß (2013) "Nonlinearity in capand-trade systems: The EUA price and its fundamentals," Energy Economics, Vol. 40, pp. $222-232$.

Neuhoff, Karsten, Kim Keats Martinez, and Misato Sato (2006) "Allocation, incentives and distortions: The impact of EU ETS emissions allowance allocations to the electricity sector," Climate Policy, Vol. 6, No. 1, pp. 73-91.

Newey, Whitney K. and Kenneth D. West (1994) "Automatic lag selection in covariance matrix estimation," The Review of Economic Studies, Vol. 61, No. 4, pp. 631-653.

Parry, Ian WH (1995) "Pollution taxes and revenue recycling," Journal of Environmental Economics and management, Vol. 29, No. 3, pp. S-64-S-77.

Sartor, Oliver, Stephen Lecourt, and Clement Palliere (2015) "Benchmark-based free allocations in EU ETS Phase 3: How much better than Phase 2?" in Marc Gronwald and Beat Hintermann eds. Emissions trading as a policy instrument, Cambridge: MIT Press. 
Schneider, C. (1998) "Stromgestehungskosten von Grosskraftwerken-Entwicklungen im Spannungsfeld von Liberalisierung und Ökosteuern,'Technical Report Band 112, ÖkoInstitut.

Seade, Jesus (1985) "Profitable cost increases and the shifting of taxation: equilibrium response of markets in Oligopoly," University of Warwick, Department of Economics Working Paper, No. 260.

Sijm, Jos, S. Hers, Wietze Lise, and B. Wetzelaer (2008) "The impact of the EU ETS on electricity prices." Final report to DG Environment of the European Commission.

Sijm, Jos, Karsten Neuhoff, and Yihsu Chen (2006) "CO2 Cost Pass Through and Windfall Profits in the Power Sector," Climate Policy, Vol. 6, No. 1, pp. 49-72.

Smale, Robin, Murray Hartley, Cameron Hepburn, John Ward, and Michael Grubb (2006) "The impact of $\mathrm{CO} 2$ emissions trading on firm profits and market prices," Climate Policy, Vol. 6, No. 1, pp. 29-46.

Unger, Darren P. and Howard J. Herzog (1998) "Comparative study on energy and R \& D performance: Gas turbine case study,”Technical report, Energy Laboratory, Massachussetts Institute of Technology.

Wuensch, Marco, Eva-Maria Klotz, Marcus Koepp, and Gesine Steudle (2013) "Massnahmen zur nachhaltigen Integration von Systemen zur gekoppelten Strom- und Waermebereitstellung in das neue Energieversorgungssystem." Prognos.

Zachmann, Georg and Christian von Hirschhausen (2008) "First evidence of asymmetric cost pass-through of EU emissions allowances: Examining wholesale electricity prices in Germany," Economics Letters, Vol. 99, No. 3, pp. 465-469. 


\section{Appendix}

\section{A1 Estimation bias in price and spread regressions}

\section{A1.1 Price regression}

If the heat rate and the emission factor of the MGU are not independent of fuel prices, we cannot factor out average heat rates and emission efficiencies. Re-writing (8) while suppressing the constant, time dummies and control variables $X_{t}$ for convenience leads to

$$
\begin{aligned}
& P_{t}^{E}=\sum_{F=C, G, O} \beta_{F} P_{t}^{F}+\beta_{A} P_{t}^{A}+\nu_{t} \\
& \nu_{t}=\sum_{F=C, G, O}\left(\alpha_{F} h r_{t}^{F, m}-\beta_{F}\right) \cdot P_{t}^{F}+\sum_{F=C, G, O}\left(\alpha_{A} h r_{t}^{F, m} e f^{F}-\beta_{A}\right) \cdot P_{t}^{A}+u_{t}
\end{aligned}
$$

In order for the $\beta^{\prime} s$ to be unbiased, the corresponding input price has to be uncorrelated with the error term. For example, the coefficient of the coal price is unbiased if the following expression is zero:

$$
\begin{aligned}
E\left[P_{t}^{C} \cdot \nu_{t}\right] & =\sum_{F=C, G, O} E\left[P_{t}^{C} P_{t}^{F} \cdot\left(\alpha_{F} h r_{t}^{F, m}-\beta_{F}\right)\right] \\
& +E\left[P_{t}^{C} \cdot P_{t}^{A} \cdot \sum_{F=C, G, O}\left(\alpha_{A} h r_{t}^{F, m} e f_{t}^{F}-\beta_{A}\right)\right]+E\left[P_{t}^{C} \cdot u_{t}\right]
\end{aligned}
$$

If the heat rate and the emission factor of the marginal generator are independent of input prices, the $\beta^{\prime} s$ and the $\alpha^{\prime} s$ are as defined in (9)-(10), such that the terms in parentheses, evaluated at their means, are zero. However, if heat rates, emission factors and input prices covary, the above expression generally differs from zero, which in turn implies that the OLS estimate for $\beta_{C}$ is a biased estimate for the marginal effect of the coal price on the electricity price. The same logic applies to the coefficients of the other input prices as well.

\section{A1.2 Spread regression}

Regressing fuel spreads on allowance prices requires an assumption about a particular technology being on the margin in a given load period, as well as an average heat rate for that technology. For example, to compute the dark spread as defined by the EEX, coal is assumed 
to be the marginal technology, with an average heat rate of 2.63 (corresponding to an efficiency of $38 \%$ ). Comparing such a regression to (7)-(8) and making the independence assumption leads to the following interpretation of the allowance price coefficient and the error term:

$$
\begin{aligned}
P_{t}^{E}-2.63 \cdot P_{t}^{C} & =\beta_{A} \cdot P_{t}^{A}+\omega_{t} \\
\beta_{A} & =\alpha_{A} \cdot \sum_{F=C, G, O} \overline{h r_{m}^{F}} e f^{F} \cdot\left(T_{F} / T\right) \\
\omega_{t} & =\left(\alpha_{F} \overline{h r} r_{m}^{C}-2.63\right) P_{t}^{C}+\alpha_{F}\left(\overline{h r}{ }^{G} P_{t}^{G}+\overline{h r}^{O} P_{t}^{O}\right)+u_{t}
\end{aligned}
$$

An unbiased estimate for $\beta_{A}$ requires that $E\left[P_{t}^{A} \cdot \omega_{t}\right]=0$. Because fuel and allowance prices are related, the OLS estimator for $\beta_{A}$ is unbiased only if both parentheses in (A6) are zero, which is the case if $\alpha_{F} \overline{h r}{ }^{C}=2.63$ and $\overline{h r}{ }^{G}=\overline{h r}^{O}=0$. Intuitively, fuel cost pass-through has to be complete $\left(\alpha_{F}=1\right)$, the heat rate assumed for the spread regression corresponds to the actual unconditional heat rate $h_{r}{ }^{C}$, and no other fuel is marginal during the chosen load period. Under these assumptions, (A5) can be solved for

$$
\alpha_{A}=\frac{\beta_{A}}{2.63 \cdot e f^{C}}
$$

which is an unbiased estimate for allowance cost-pass-through. If, however, these conditions do not hold (for example, if gas is marginal during some offpeak hours), then this estimator for pass-through is biased. The restrictions that have to be imposed to obtain unbiased estimates for cost pass-through using electricity spreads therefore exceed those required for the price model.

\section{A2 Computation of marginal input costs}

\section{A2.1 Calibration of hourly demand and supply to monthly levels}

Residual demand for fossil-generated electricity is defined as total generation net of must-run generation. Total generation has to be equal to the sum of total demand from consumers and industry, net exports and the electricity used to operate the pumps that serve pumped hydro storage. Must-run generation is the sum of nuclear, hydro, other renewables (wind, solar, 
biomass), lignite and "other" fossil fuel (i.e., other than lignite, coal, gas and oil). Wherever available, I use hourly values for these groups. However, as discussed in the main text, the hourly values aggregated to the monthly level typically do not coincide with the monthly values reported by ENTSO-E. Since the latter is more complete, I calibrate everything to the monthly data. For demand, nuclear, lignite and hydro, I multiplied the hourly values by a monthly scaling factor.

For pump use, no hourly values are available. I therefore divided the monthly values reported by ENTSO-E by the number of offpeak hours per month, under the assumption that no pumping takes place during peak hours. For other fossil fuels, no hourly values are given either. Since this type of generation (mostly non-biogenic part of waste and peat) tends to run continuously, I divide it equally among all hours of the month.

There is a significant hourly variation in renewable generation and in net exports. Applying a correction factor that is greater than one and constant within a month leads to very high generation by renewables during some hours (leading to negative residual demand), and to net exports that exceed the total capacity. For some months, even the sign of aggregated hourly and reported monthly net exports disagrees, which would lead to a negative correction factor and thus a switch of all imports into exports, and vice versa, for that month. For these reasons, I use an additive correction amount rather than a multiplicative scaling factor to ensure that the monthly and hourly values coincide. I divide this correction amount (which can be negative or negative) equally among all hours of a month.

Note that although there exist hourly values for generation by coal, gas and oil, these are based on voluntary and partial reporting and thus cannot be used to check my model. For 2013, the only year for which such a comparison is possible, the aggregated hourly values differ by the reported monthly totals by a factor of up to 4 , depending on the month. Also, there is a problem with the way generation by process gases is treated (burnable gases that arise as a by-product during industrial processes). Whereas ENTSO-E includes generation by process gas in its "Gas" category along with natural gas, at least some process gas generators appear under the heading of "other fossil" in the hourly data. 


\section{A2.2 Computing generator efficiencies}

The UBA (Umweltbundesamt or Federal Environment Agency) database does not include information about plant efficiency, only of the fuel type and technology, and I therefore need to compute the efficiency (i.e., the inverse of the heat rate) for each generator. Because of technological progress, the efficiency is a function not only of the employed technology and the fuel input, but also of a plant's age. Specifically, I compute the efficiencies $\eta$ (in percent) as a function of plant age $y$ by

Hard coal:

Gas and oil, conventional:

Gas and oil, OCGT:

Gas, CCGT:

Relevant age for coal, OCGT and conv. :

Relevant age for CCGT plants :

$$
\begin{aligned}
& \eta(y)=0.2982 \cdot(y-1950)+28.821 \\
& \eta(y)=44 \cdot \frac{0.2982 \cdot(y-1950)+28.821}{42.24} \\
& \eta(y)=-0.0030165 \cdot(y-1952)^{2} \\
& +0.491436 \cdot(y-1952)+21.00003
\end{aligned}
$$$$
\eta(y)=0.056667 *(y-1970)+37.16667
$$$$
y=0.56 \cdot y \text { (built })+0.44 \cdot y(\text { retrofit })
$$$$
y=0.74 \cdot y \text { (built) }+0.26 \cdot y(\text { retrofit })
$$

The formula for coal in (A8) is taken from Folke (2000, p.47). The efficiency computed with this formula closely matches the reported efficiencies for 10 coal generators in my dataset that were never retrofitted. However, the literature does not indicate how the year of retrofit, if any, should be weighted relative to the year of original plant construction. Based on 7 retrofitted coal generators for which efficiency information, I derived weights for year built and year retrofitted of 0.56 vs. 0.44 , respectively. These weights were also applied to conventional oil and gas plants, and to OCGT plants. Overall, the computed efficiency deviates from the reported efficiency of the 17 coal plants, for which I have this data, by 0.11 percentage points.

For conventional oil and gas plants, Folke (2000, p.47) assumes that the rate of technological progress matches that of coal plants. This leads to formula (A9), where 44 refers to the efficiency of a representative conventional oil plant in 1995 (Hoster, 1996, p.49) and 42.24 is the efficiency of a representative coal generator in that year, computed based on (A8) .

For OCGT plants, there is no formula from the literature that could directly be tested, nor 
was I able to find efficiencies for the OCGT plants in my sample. Instead, I use data from Unger and Herzog (1998), Hoster (1996) and Schneider (1998) and compute the empirical formula in (A10) based on a second-order polynomial regression.

There is no external data nor formula for the efficiency of CCGT. However, I was able to obtain efficiencies for 11 non-retrofitted CCGT plants in my sample and computed equation (A11). Because retrofits to a CCGT plants typically only involve the second stage but not the first, the implications of retrofitting for overall plant efficiency will arguably differ relative to retrofits of plants that have a single cycle. I computed a separate weighting for the revision date for 7 CCGT plants in my sample for which I found data. This yielded weights for the year of construction and of retrofit of 0.74 and 0.26 , respectively.

\section{A2.3 CPH generation}

Without further adjustments, my merit order model would lead to very little generation by gas, and practically no generation by oil, which contradicts data on the annual level. The reason is that some combined power and heat $(\mathrm{CPH})$ plants are operated based on heat requirements rather than electric output. We know which generators are $\mathrm{CPH}$ generators, but we don't know to which extent and during which hours they are operated based on heat requirements. Total $\mathrm{CPH}$ generation by gas was reported to be 55.7 TWH in 2010 (Eurelectric, 2012, p. 169), and 52.9 TWh in 2012 (Statista, available at de.statista.com). I was unable to find corresponding numbers for 2011 and 2013, but since total generation by gas in 2013 was 47 TWh, I assume that the vast majority came from CPH plants. I fill in the value for 2011 by interpolation. Let $H$ be the amount of gas-based CHP generation in a year, and let $0 \leq q \leq 1$ be the share of this generation that is based on heat requirements. I then distribute the amount $q \cdot H$ among the twelve months of the year by using a weighted average of a representative heat profile for households (Wuensch et al., 2013, p. 41) and industrial requirement for process heat (assumed to be constant throughout the year), with the weights corresponding to the relative importance of household vs. industrial demand (Wuensch et al., 2013, p. 11). Dividing the resulting heat-based monthly generation by the number of hours 
in a given month gives the hourly amount of heat-optimized gas generation

$$
h_{t}=q \cdot H \cdot \operatorname{share}_{t}^{m} / n_{t}
$$

where share $t_{t}^{m}$ is the share of heat-based generation and $n_{t}$ is the number of hours in the month to which hour $t$ belongs. Let $\mathrm{cap}_{t}^{c p h}$ be the gas-based CPH capacity in hour $t$ (recall that due to outages, this capacity varies by hour). For each hour, I assign a share of the total $\mathrm{CPH}$ capacity given by

$$
\min \left\{\frac{h_{t}}{\operatorname{cap}_{t}^{c p h}}, 1\right\}
$$

to a generic generator with zero marginal cost, such that it is always located at the bottom of the merit order. To keep the total amount of $\mathrm{CPH}$ capacity constant, I then assign each $\mathrm{CPH}$ generator a dummy that is equal to zero with a probability given by (A14), and equal to one otherwise, and multiply its capacity with this dummy in the context of the Monte-Carlo analysis described in the main text. For example, if $25 \%$ of total CPH capacity is needed to provide heat in a given hour, I assign a quarter of total CPH capacity to a generic generator at the bottom of the merit order and switch off all CPH generators with a probability of $25 \%$. Last, I choose the level of $q$ such that total gas generation in 2013 coincides with the reported gas generation. This led to $q=0.94$, implying that most $\mathrm{CPH}$ generation is in fact based on heat rather than electric output. Note, however, that this number depends on the opportunity cost selected for plants that run on process gas. As discussed in the main text, when dropping the opportunity cost from $75 \%$ of the price for natural gas to only $25 \%$, the heat-optimized share of $\mathrm{CPH}$ output required to calibrate the model to 2013 data drops to $\mathrm{q}=0.73$.

For oil-based $\mathrm{CPH}$, I assign a certain fraction of the capacity of three generators identified as $\mathrm{CPH}$ generators to the bottom of the merit order during the entire year, and an additional fraction during the winter months only, until monthly oil generation aggregated to the monthly level matches up with monthly generation reported for 2013. 


\section{A3 Additional regression results}

Table A1: First-stage and reduced-form results from the base model, for all hours and peak/offpeak (corresponding to the second-stage results in columns 1-2 in Table 3)

\begin{tabular}{|c|c|c|c|c|c|c|c|c|}
\hline & \multicolumn{3}{|c|}{ Baseload (all hours) } & \multicolumn{5}{|c|}{ Peak vs. offpeak hours } \\
\hline & FC & CC & $\mathrm{RF}$ & FC & FC*Peak & $\mathrm{CC}$ & CC*Peak & $\mathrm{RF}$ \\
\hline Coal & $\begin{array}{c}2.485^{* * *} \\
(0.177)\end{array}$ & $\begin{array}{c}-0.104^{* * *} \\
(0.0310)\end{array}$ & $\begin{array}{c}2.256^{* * *} \\
(0.322)\end{array}$ & $\begin{array}{c}2.475^{* * *} \\
(0.168)\end{array}$ & $\begin{array}{c}0.208^{* *} \\
(0.0753)\end{array}$ & $\begin{array}{c}-0.0984^{* * *} \\
(0.0298)\end{array}$ & $\begin{array}{c}-0.453^{* * *} \\
(0.0305)\end{array}$ & $\begin{array}{c}2.175^{* * *} \\
(0.301)\end{array}$ \\
\hline Coal*Peak* & & & & $\begin{array}{l}0.0187 \\
(0.134)\end{array}$ & $\begin{array}{c}2.530^{* * *} \\
(0.159)\end{array}$ & $\begin{array}{c}-0.0128 \\
(0.0312)\end{array}$ & $\begin{array}{l}1.084^{* * *} \\
(0.0580)\end{array}$ & $\begin{array}{c}0.243 \\
(0.232)\end{array}$ \\
\hline Gas & $\begin{array}{c}-0.641 \\
(0.608)\end{array}$ & $\begin{array}{c}0.00940 \\
(0.109)\end{array}$ & $\begin{array}{l}-1.865^{*} \\
(0.811)\end{array}$ & $\begin{array}{c}-0.743 \\
(0.604)\end{array}$ & $\begin{array}{c}-0.650 \\
(0.373)\end{array}$ & $\begin{array}{l}0.0384 \\
(0.106)\end{array}$ & $\begin{array}{l}0.309^{* * *} \\
(0.0581)\end{array}$ & $\begin{array}{l}-1.894^{*} \\
(0.772)\end{array}$ \\
\hline Gas*Peak & & & & $\begin{array}{l}0.301^{* * *} \\
(0.0560)\end{array}$ & $\begin{array}{l}0.553^{* * *} \\
(0.0668)\end{array}$ & $\begin{array}{c}-0.0941^{* * *} \\
(0.0110)\end{array}$ & $\begin{array}{c}-0.627^{* * *} \\
(0.0185)\end{array}$ & $\begin{array}{l}-0.00311 \\
(0.0788)\end{array}$ \\
\hline Gas sqared & $\begin{array}{c}0.0264 \\
(0.0158)\end{array}$ & $\begin{array}{l}-0.000778 \\
(0.00247)\end{array}$ & $\begin{array}{l}0.0573^{* *} \\
(0.0201)\end{array}$ & $\begin{array}{c}0.0264 \\
(0.0156)\end{array}$ & $\begin{array}{c}0.0150 \\
(0.00936)\end{array}$ & $\begin{array}{l}-0.000696 \\
(0.00240)\end{array}$ & $\begin{array}{c}-0.00261 \\
(0.00140)\end{array}$ & $\begin{array}{l}0.0581^{* *} \\
(0.0193)\end{array}$ \\
\hline EUA & $\begin{array}{c}0.101 \\
(0.0786)\end{array}$ & $\begin{array}{l}0.721^{* * *} \\
(0.0108)\end{array}$ & $\begin{array}{c}0.895^{* * *} \\
(0.137)\end{array}$ & $\begin{array}{c}0.103 \\
(0.0763)\end{array}$ & $\begin{array}{c}-0.0522 \\
(0.0417)\end{array}$ & $\begin{array}{l}0.721^{* * *} \\
(0.0107)\end{array}$ & $\begin{array}{l}0.266^{* * *} \\
(0.0127)\end{array}$ & $\begin{array}{c}0.897^{* * *} \\
(0.129)\end{array}$ \\
\hline Peak & & & & $\begin{array}{c}-3.573^{* *} \\
(1.255)\end{array}$ & $\begin{array}{c}-6.491^{* * *} \\
(1.416)\end{array}$ & $\begin{array}{c}2.205^{* * *} \\
(0.432)\end{array}$ & $\begin{array}{c}10.80^{* * *} \\
(0.727)\end{array}$ & $\begin{array}{c}8.376^{* * *} \\
(2.451)\end{array}$ \\
\hline $\mathrm{CPH}$ & $\begin{array}{c}-15.71^{* * *} \\
(2.096)\end{array}$ & $\begin{array}{c}-5.086^{* * *} \\
(0.270)\end{array}$ & $\begin{array}{c}-34.79^{* * *} \\
(4.198)\end{array}$ & $\begin{array}{c}-15.09^{* * *} \\
(2.066)\end{array}$ & $\begin{array}{c}-1.881 \\
(1.011)\end{array}$ & $\begin{array}{c}-5.150^{* * *} \\
(0.272)\end{array}$ & $\begin{array}{c}-0.867^{* * *} \\
(0.245)\end{array}$ & $\begin{array}{c}-33.39^{* * *} \\
(4.078)\end{array}$ \\
\hline Resdem. $<0$ & $\begin{array}{c}-27.77^{* * *} \\
(0.488)\end{array}$ & $\begin{array}{c}-3.720^{* * *} \\
(0.162)\end{array}$ & $\begin{array}{c}-23.88^{* * *} \\
(4.344)\end{array}$ & $\begin{array}{c}-27.46^{* * *} \\
(0.634)\end{array}$ & $\begin{array}{l}-8.884^{*} \\
(3.928)\end{array}$ & $\begin{array}{c}-3.753^{* * *} \\
(0.211)\end{array}$ & $\begin{array}{l}-1.041^{*} \\
(0.413)\end{array}$ & $\begin{array}{c}-23.24^{* * *} \\
(5.596)\end{array}$ \\
\hline Constant & $\begin{array}{c}3.943 \\
(4.244)\end{array}$ & $\begin{array}{c}1.670 \\
(1.028)\end{array}$ & $\begin{array}{c}24.53^{* * *} \\
(6.424)\end{array}$ & $\begin{array}{c}5.149 \\
(4.271)\end{array}$ & $\begin{array}{c}5.241 \\
(2.750)\end{array}$ & $\begin{array}{c}0.932 \\
(1.015)\end{array}$ & $\begin{array}{c}-3.691^{* * *} \\
(0.474)\end{array}$ & $\begin{array}{c}21.79^{* * *} \\
(6.080)\end{array}$ \\
\hline
\end{tabular}

Note: $\mathrm{N}=35,064$ for all regressions. Standard errors in parentheses, corrected for autocorrelation and heteroskedasticity. Significance levels: ${ }^{*} p<0.05,{ }^{* *} p<0.01,{ }^{* * *} p<0.001$. The column headers refer to the endogenous regressors (fuel costs and allowance costs and their respective interaction with the Peak dummy), and $\mathrm{RF}$ stands for reduced-form. 
Table A2: First-stage and reduced-form results from the base model: High vs. low vs. other hours (corresponding to the second-stage results in column 1 in Table 4)

\begin{tabular}{|c|c|c|c|c|c|c|c|}
\hline & $\begin{array}{l}\text { (1) } \\
\text { FC }\end{array}$ & $\begin{array}{c}(2) \\
\text { FC*Low }^{*}\end{array}$ & $\begin{array}{c}(3) \\
\mathrm{FC}^{*} \mathrm{High}\end{array}$ & $\begin{array}{l}\text { (4) } \\
\text { CC }\end{array}$ & $\begin{array}{c}\text { (5) } \\
\text { CC*Low }\end{array}$ & $\begin{array}{c}\text { (6) } \\
\text { CC*High }\end{array}$ & $\begin{array}{l}\text { (7) } \\
\text { RF }\end{array}$ \\
\hline Coal & $\begin{array}{c}2.441^{* * *} \\
(0.180)\end{array}$ & $\begin{array}{c}-0.185^{* * *} \\
(0.023)\end{array}$ & $\begin{array}{c}0.099^{*} \\
(0.045)\end{array}$ & $\begin{array}{c}-0.096^{* *} \\
(0.032)\end{array}$ & $\begin{array}{c}-0.248^{* * *} \\
(0.015)\end{array}$ & $\begin{array}{c}-0.238^{* * *} \\
(0.015)\end{array}$ & $\begin{array}{c}2.158^{* * *} \\
(0.332)\end{array}$ \\
\hline Coal*Low & $\begin{array}{c}0.107 \\
(0.102)\end{array}$ & $\begin{array}{c}2.533^{* * *} \\
(0.102)\end{array}$ & $\begin{array}{c}0.002 \\
(0.002)\end{array}$ & $\begin{array}{c}0.009 \\
(0.023)\end{array}$ & $\begin{array}{c}1.089^{* * *} \\
(0.055)\end{array}$ & $\begin{array}{c}0.000 \\
(0.001)\end{array}$ & $\begin{array}{c}-0.022 \\
(0.163)\end{array}$ \\
\hline Coal*High & $\begin{array}{c}0.035 \\
(0.140)\end{array}$ & $\begin{array}{c}0.017 \\
(0.012)\end{array}$ & $\begin{array}{c}2.443^{* * *} \\
(0.191)\end{array}$ & $\begin{array}{c}-0.054 \\
(0.029)\end{array}$ & $\begin{array}{c}0.005 \\
(0.007)\end{array}$ & $\begin{array}{c}1.023^{* * *} \\
(0.060)\end{array}$ & $\begin{array}{c}0.477^{*} \\
(0.211)\end{array}$ \\
\hline Gas & $\begin{array}{c}-0.612 \\
(0.600)\end{array}$ & $\begin{array}{c}0.242^{* * *} \\
(0.065)\end{array}$ & $\begin{array}{c}-0.315 \\
(0.234)\end{array}$ & $\begin{array}{c}0.013 \\
(0.106)\end{array}$ & $\begin{array}{c}0.012 \\
(0.026)\end{array}$ & $\begin{array}{c}0.153^{* * *} \\
(0.030)\end{array}$ & $\begin{array}{l}-1.719^{*} \\
(0.781)\end{array}$ \\
\hline Gas*Low & $\begin{array}{c}-0.346^{* * *} \\
(0.039)\end{array}$ & $\begin{array}{c}-0.016 \\
(0.028)\end{array}$ & $\begin{array}{c}0.001 \\
(0.001)\end{array}$ & $\begin{array}{c}0.066^{* * *} \\
(0.008)\end{array}$ & $\begin{array}{c}-0.504^{* * *} \\
(0.015)\end{array}$ & $\begin{array}{c}0.000 \\
(0.000)\end{array}$ & $\begin{array}{c}-0.239^{* * *} \\
(0.054)\end{array}$ \\
\hline Gas*High & $\begin{array}{c}0.429^{* * *} \\
(0.056)\end{array}$ & $\begin{array}{l}-0.011^{*} \\
(0.005)\end{array}$ & $\begin{array}{c}0.807^{* * *} \\
(0.084)\end{array}$ & $\begin{array}{c}-0.128^{* * *} \\
(0.012)\end{array}$ & $\begin{array}{l}-0.004^{*} \\
(0.002)\end{array}$ & $\begin{array}{c}-0.683^{* * *} \\
(0.017)\end{array}$ & $\begin{array}{c}-0.367^{* * *} \\
(0.075)\end{array}$ \\
\hline Gas sqared & $\begin{array}{c}0.026 \\
(0.016)\end{array}$ & $\begin{array}{l}-0.004^{*} \\
(0.002)\end{array}$ & $\begin{array}{c}0.007 \\
(0.006)\end{array}$ & $\begin{array}{c}-0.001 \\
(0.002)\end{array}$ & $\begin{array}{c}0.003^{* * *} \\
(0.001)\end{array}$ & $\begin{array}{c}-0.001 \\
(0.001)\end{array}$ & $\begin{array}{l}0.057^{* *} \\
(0.019)\end{array}$ \\
\hline EUA & $\begin{array}{c}0.107 \\
(0.078)\end{array}$ & $\begin{array}{c}0.077^{* * *} \\
(0.016)\end{array}$ & $\begin{array}{c}-0.024 \\
(0.028)\end{array}$ & $\begin{array}{c}0.721^{* * *} \\
(0.011)\end{array}$ & $\begin{array}{c}0.165^{* * *} \\
(0.003)\end{array}$ & $\begin{array}{c}0.141^{* * *} \\
(0.006)\end{array}$ & $\begin{array}{c}0.907^{* * *} \\
(0.133)\end{array}$ \\
\hline Low & $\begin{array}{c}3.737^{* * *} \\
(0.900)\end{array}$ & $\begin{array}{c}0.980 \\
(0.746)\end{array}$ & $\begin{array}{c}-0.035 \\
(0.031)\end{array}$ & $\begin{array}{c}-1.477^{* * *} \\
(0.327)\end{array}$ & $\begin{array}{c}8.028^{* * *} \\
(0.629)\end{array}$ & $\begin{array}{c}-0.001 \\
(0.014)\end{array}$ & $\begin{array}{l}-3.245^{*} \\
(1.637)\end{array}$ \\
\hline High & $\begin{array}{c}-6.184^{* * *} \\
(1.129)\end{array}$ & $\begin{array}{c}-0.023 \\
(0.122)\end{array}$ & $\begin{array}{c}-9.498^{* * *} \\
(1.522)\end{array}$ & $\begin{array}{c}3.426^{* * *} \\
(0.437)\end{array}$ & $\begin{array}{c}-0.006 \\
(0.068)\end{array}$ & $\begin{array}{c}12.748^{* * *} \\
(0.695)\end{array}$ & $\begin{array}{c}12.327^{* * *} \\
(2.260)\end{array}$ \\
\hline $\mathrm{CPH}$ & $\begin{array}{c}-14.351^{* * *} \\
(2.087)\end{array}$ & $\begin{array}{c}-5.532^{* * *} \\
(1.136)\end{array}$ & $\begin{array}{c}-0.497 \\
(0.384)\end{array}$ & $\begin{array}{c}-5.184^{* * *} \\
(0.268)\end{array}$ & $\begin{array}{c}-2.241^{* * *} \\
(0.198)\end{array}$ & $\begin{array}{c}0.013 \\
(0.083)\end{array}$ & $\begin{array}{c}-32.163^{* * *} \\
(4.188)\end{array}$ \\
\hline Resdem. $<0$ & $\begin{array}{c}-27.165^{* * *} \\
(0.573)\end{array}$ & $\begin{array}{c}-5.250^{* * *} \\
(1.144)\end{array}$ & $\begin{array}{c}-2.075 \\
(1.615)\end{array}$ & $\begin{array}{c}-3.772^{* * *} \\
(0.182)\end{array}$ & $\begin{array}{c}-0.916^{* * *} \\
(0.226)\end{array}$ & $\begin{array}{c}-0.174 \\
(0.154)\end{array}$ & $\begin{array}{c}-23.232^{* * *} \\
(4.763)\end{array}$ \\
\hline Constant & $\begin{array}{c}3.919 \\
(4.215)\end{array}$ & $\begin{array}{c}-2.064^{* * *} \\
(0.511)\end{array}$ & $\begin{array}{c}2.549 \\
(1.715)\end{array}$ & $\begin{array}{c}1.457 \\
(1.028)\end{array}$ & $\begin{array}{c}-0.855^{* * *} \\
(0.224)\end{array}$ & $\begin{array}{c}-1.863^{* * *} \\
(0.239)\end{array}$ & $\begin{array}{c}22.921^{* * *} \\
(6.161)\end{array}$ \\
\hline
\end{tabular}

Note: $\mathrm{N}=35,064$ for all regressions. Standard errors in parentheses, corrected for autocorrelation and heteroskedasticity. Significance levels: ${ }^{*} p<0.05,{ }^{* *} p<0.01$, ${ }^{* * *} p<0.001$. The column headers refer to the endogenous regressors (fuel costs and allowance costs and their respective interaction with the "Low" and "High" dummies), and RF stands for reduced-form. 
Table A3: First-stage and reduced-form results from model with yearly and monthly dummies: All hours and peak/offpeak (corresponding to the second-stage results in columns 3-4 in Table 3

\begin{tabular}{|c|c|c|c|c|c|c|c|c|}
\hline & \multicolumn{3}{|c|}{ Baseload (all hours) } & \multicolumn{5}{|c|}{ Peak vs. offpeak hours } \\
\hline & FC & CC & $\mathrm{RF}$ & FC & FC*Peak & CC & CC*Peak & $\mathrm{RF}$ \\
\hline Coal & $\begin{array}{c}1.738^{* * *} \\
(0.379)\end{array}$ & $\begin{array}{c}-0.0926 \\
(0.0667)\end{array}$ & $\begin{array}{l}1.593^{*} \\
(0.687)\end{array}$ & $\begin{array}{c}1.703^{* * *} \\
(0.370)\end{array}$ & $\begin{array}{c}-0.304 \\
(0.183)\end{array}$ & $\begin{array}{c}-0.0835 \\
(0.0668)\end{array}$ & $\begin{array}{c}-0.386^{* * *} \\
(0.0492)\end{array}$ & $\begin{array}{l}1.473^{*} \\
(0.664)\end{array}$ \\
\hline Coal*Peak* & & & & $\begin{array}{l}0.0279 \\
(0.131)\end{array}$ & $\begin{array}{c}2.534^{* * *} \\
(0.157)\end{array}$ & $\begin{array}{c}-0.0132 \\
(0.0310)\end{array}$ & $\begin{array}{l}1.084^{* * *} \\
(0.0578)\end{array}$ & $\begin{array}{c}0.232 \\
(0.230)\end{array}$ \\
\hline Gas & $\begin{array}{c}-0.846 \\
(0.555)\end{array}$ & $\begin{array}{l}0.0447 \\
(0.143)\end{array}$ & $\begin{array}{l}-0.167 \\
(0.953)\end{array}$ & $\begin{array}{l}-0.912 \\
(0.542)\end{array}$ & $\begin{array}{l}-0.708^{*} \\
(0.332)\end{array}$ & $\begin{array}{l}0.0691 \\
(0.139)\end{array}$ & $\begin{array}{c}0.275^{* *} \\
(0.0851)\end{array}$ & $\begin{array}{c}-0.122 \\
(0.901)\end{array}$ \\
\hline Gas*Peak & & & & $\begin{array}{l}0.302^{* * *} \\
(0.0541)\end{array}$ & $\begin{array}{l}0.553^{* * *} \\
(0.0661)\end{array}$ & $\begin{array}{c}-0.0940^{* * *} \\
(0.0110)\end{array}$ & $\begin{array}{c}-0.627^{* * *} \\
(0.0185)\end{array}$ & $\begin{array}{r}-0.00222 \\
(0.0768)\end{array}$ \\
\hline Gas sqared & $\begin{array}{c}0.0363^{*} \\
(0.0142)\end{array}$ & $\begin{array}{c}-0.00172 \\
(0.00306)\end{array}$ & $\begin{array}{c}0.0223 \\
(0.0223)\end{array}$ & $\begin{array}{c}0.0355^{*} \\
(0.0139)\end{array}$ & $\begin{array}{c}0.0188^{*} \\
(0.00830)\end{array}$ & $\begin{array}{c}-0.00154 \\
(0.00298)\end{array}$ & $\begin{array}{c}-0.00246 \\
(0.00200)\end{array}$ & $\begin{array}{c}0.0212 \\
(0.0210)\end{array}$ \\
\hline EUA & $\begin{array}{c}0.199 \\
(0.118)\end{array}$ & $\begin{array}{l}0.741^{* * *} \\
(0.0198)\end{array}$ & $\begin{array}{c}0.891^{* * *} \\
(0.217)\end{array}$ & $\begin{array}{c}0.197 \\
(0.114)\end{array}$ & $\begin{array}{c}0.0402 \\
(0.0646)\end{array}$ & $\begin{array}{l}0.741^{* * *} \\
(0.0195)\end{array}$ & $\begin{array}{l}0.297^{* * *} \\
(0.0184)\end{array}$ & $\begin{array}{c}0.884^{* * *} \\
(0.207)\end{array}$ \\
\hline Peak & & & & $\begin{array}{c}-3.684^{* *} \\
(1.224)\end{array}$ & $\begin{array}{c}-6.542^{* * *} \\
(1.400)\end{array}$ & $\begin{array}{c}2.207^{* * *} \\
(0.431)\end{array}$ & $\begin{array}{c}10.81^{* * *} \\
(0.725)\end{array}$ & $\begin{array}{c}8.415^{* * *} \\
(2.390)\end{array}$ \\
\hline $\mathrm{CPH}$ & $\begin{array}{c}-15.58^{* * *} \\
(2.131)\end{array}$ & $\begin{array}{c}-5.129^{* * *} \\
(0.269)\end{array}$ & $\begin{array}{c}-34.90^{* * *} \\
(4.048)\end{array}$ & $\begin{array}{c}-14.97^{* * *} \\
(2.102)\end{array}$ & $\begin{array}{l}-1.909 \\
(1.022)\end{array}$ & $\begin{array}{c}-5.194^{* * *} \\
(0.272)\end{array}$ & $\begin{array}{c}-0.927^{* * *} \\
(0.244)\end{array}$ & $\begin{array}{c}-33.51^{* * *} \\
(3.937)\end{array}$ \\
\hline Resdem. $<0$ & $\begin{array}{c}-26.55^{* * *} \\
(0.525)\end{array}$ & $\begin{array}{c}-3.698^{* * *} \\
(0.164)\end{array}$ & $\begin{array}{c}-23.32^{* * *} \\
(3.672)\end{array}$ & $\begin{array}{c}-26.23^{* * *} \\
(0.787)\end{array}$ & $\begin{array}{l}-8.116^{*} \\
(4.059)\end{array}$ & $\begin{array}{c}-3.732^{* * *} \\
(0.214)\end{array}$ & $\begin{array}{l}-1.062^{*} \\
(0.416)\end{array}$ & $\begin{array}{c}-22.70^{* * *} \\
(4.873)\end{array}$ \\
\hline year $=2010$ & $\begin{array}{l}10.50^{*} \\
(4.330)\end{array}$ & $\begin{array}{c}1.055 \\
(1.125)\end{array}$ & $\begin{array}{c}10.17 \\
(7.483)\end{array}$ & $\begin{array}{l}11.72^{* *} \\
(4.307)\end{array}$ & $\begin{array}{c}9.173^{* * *} \\
(2.594)\end{array}$ & $\begin{array}{c}0.328 \\
(1.107)\end{array}$ & $\begin{array}{c}-4.016^{* * *} \\
(0.543)\end{array}$ & $\begin{array}{c}7.463 \\
(7.203)\end{array}$ \\
\hline year $=2011$ & $\begin{array}{l}11.11^{*} \\
(4.371)\end{array}$ & $\begin{array}{c}1.025 \\
(1.157)\end{array}$ & $\begin{array}{c}9.720 \\
(7.861)\end{array}$ & $\begin{array}{l}12.36^{* *} \\
(4.341)\end{array}$ & $\begin{array}{c}9.818^{* * *} \\
(2.577)\end{array}$ & $\begin{array}{c}0.297 \\
(1.138)\end{array}$ & $\begin{array}{c}-4.002^{* * *} \\
(0.551)\end{array}$ & $\begin{array}{c}7.104 \\
(7.578)\end{array}$ \\
\hline year $=2012$ & $\begin{array}{l}12.29^{* *} \\
(4.644)\end{array}$ & $\begin{array}{c}1.242 \\
(1.229)\end{array}$ & $\begin{array}{c}8.728 \\
(8.144)\end{array}$ & $\begin{array}{l}13.46^{* *} \\
(4.599)\end{array}$ & $\begin{array}{c}10.76^{* * *} \\
(2.755)\end{array}$ & $\begin{array}{c}0.524 \\
(1.203)\end{array}$ & $\begin{array}{c}-3.666^{* * *} \\
(0.585)\end{array}$ & $\begin{array}{c}5.970 \\
(7.864)\end{array}$ \\
\hline year $=2013$ & $\begin{array}{c}7.341 \\
(4.408)\end{array}$ & $\begin{array}{c}1.316 \\
(1.296)\end{array}$ & $\begin{array}{c}7.428 \\
(8.248)\end{array}$ & $\begin{array}{c}8.476 \\
(4.353)\end{array}$ & $\begin{array}{l}7.740^{* *} \\
(2.660)\end{array}$ & $\begin{array}{c}0.605 \\
(1.267)\end{array}$ & $\begin{array}{c}-3.333^{* * *} \\
(0.629)\end{array}$ & $\begin{array}{c}4.603 \\
(7.958)\end{array}$ \\
\hline
\end{tabular}

Note: $\mathrm{N}=35,064$ for all regressions. Standard errors in parentheses, corrected for autocorrelation and heteroskedasticity. Significance levels: ${ }^{*} p<0.05,{ }^{* *} p<0.01,{ }^{* * *} p<0.001$. The column headers refer to the endogenous regressors (fuel costs and allowance costs and their respective interaction with the peak dummy), and RF stands for reduced-form. The coefficients for the monthly dummies are suppressed. 
Table A4: First-stage and reduced-form results from the model with yearly and monthly dummies: High vs. low vs. other hours (corresponding to the second-stage results in column 2 in Table 4)

\begin{tabular}{|c|c|c|c|c|c|c|c|}
\hline & $\begin{array}{l}\text { (1) } \\
\text { FC }\end{array}$ & $\begin{array}{c}(2) \\
\text { FC*Low }\end{array}$ & $\begin{array}{c}(3) \\
\text { FC*High }\end{array}$ & $\begin{array}{l}\text { (4) } \\
\text { CC }\end{array}$ & $\begin{array}{c}\text { (5) } \\
\text { CC*Low }\end{array}$ & $\begin{array}{c}\text { (6) } \\
\text { CC*High }\end{array}$ & $\begin{array}{l}\text { (7) } \\
\text { RF }\end{array}$ \\
\hline Coal & $\begin{array}{c}1.678^{* * *} \\
(0.377)\end{array}$ & $\begin{array}{l}-0.167^{* *} \\
(0.0614)\end{array}$ & $\begin{array}{l}-0.247^{*} \\
(0.125)\end{array}$ & $\begin{array}{c}-0.0824 \\
(0.0655)\end{array}$ & $\begin{array}{c}-0.291^{* * *} \\
(0.0203)\end{array}$ & $\begin{array}{c}-0.169^{* * *} \\
(0.0243)\end{array}$ & $\begin{array}{c}1.466^{*} \\
(0.680)\end{array}$ \\
\hline Coal*Low & $\begin{array}{c}0.106 \\
(0.102)\end{array}$ & $\begin{array}{c}2.533^{* * *} \\
(0.102)\end{array}$ & $\begin{array}{c}0.00186 \\
(0.00315)\end{array}$ & $\begin{array}{l}0.00861 \\
(0.0229)\end{array}$ & $\begin{array}{l}1.089^{* * *} \\
(0.0555)\end{array}$ & $\begin{array}{l}0.000130 \\
(0.00128)\end{array}$ & $\begin{array}{l}-0.0188 \\
(0.163)\end{array}$ \\
\hline Coal*High & $\begin{array}{l}0.0344 \\
(0.134)\end{array}$ & $\begin{array}{c}0.0170 \\
(0.0128)\end{array}$ & $\begin{array}{c}2.442^{* * *} \\
(0.189)\end{array}$ & $\begin{array}{l}-0.0540 \\
(0.0291)\end{array}$ & $\begin{array}{c}0.00536 \\
(0.00700)\end{array}$ & $\begin{array}{l}1.023^{* * *} \\
(0.0595)\end{array}$ & $\begin{array}{l}0.488^{*} \\
(0.208)\end{array}$ \\
\hline Gas & $\begin{array}{l}-0.806 \\
(0.540)\end{array}$ & $\begin{array}{c}0.200^{*} \\
(0.0852)\end{array}$ & $\begin{array}{c}-0.496^{* *} \\
(0.178)\end{array}$ & $\begin{array}{l}0.0455 \\
(0.138)\end{array}$ & $\begin{array}{c}0.0514 \\
(0.0298)\end{array}$ & $\begin{array}{l}0.0981^{*} \\
(0.0407)\end{array}$ & $\begin{array}{l}-0.0150 \\
(0.907)\end{array}$ \\
\hline Gas*Low & $\begin{array}{c}-0.346^{* * *} \\
(0.0390)\end{array}$ & $\begin{array}{l}-0.0163 \\
(0.0282)\end{array}$ & $\begin{array}{c}0.00103 \\
(0.00160)\end{array}$ & $\begin{array}{l}0.0658^{* * *} \\
(0.00843)\end{array}$ & $\begin{array}{c}-0.504^{* * *} \\
(0.0147)\end{array}$ & $\begin{array}{c}0.0000559 \\
(0.000365)\end{array}$ & $\begin{array}{c}-0.239^{* * *} \\
(0.0546)\end{array}$ \\
\hline Gas*High & $\begin{array}{l}0.432^{* * *} \\
(0.0557)\end{array}$ & $\begin{array}{c}-0.0108^{*} \\
(0.00473)\end{array}$ & $\begin{array}{l}0.808^{* * *} \\
(0.0833)\end{array}$ & $\begin{array}{c}-0.128^{* * *} \\
(0.0116)\end{array}$ & $\begin{array}{l}-0.00379^{*} \\
(0.00191)\end{array}$ & $\begin{array}{c}-0.683^{* * *} \\
(0.0175)\end{array}$ & $\begin{array}{c}-0.368^{* * *} \\
(0.0745)\end{array}$ \\
\hline Gas sqared & $\begin{array}{l}0.0358^{* *} \\
(0.0139)\end{array}$ & $\begin{array}{c}-0.00326 \\
(0.00205)\end{array}$ & $\begin{array}{c}0.0125^{* *} \\
(0.00443)\end{array}$ & $\begin{array}{l}-0.00159 \\
(0.00295)\end{array}$ & $\begin{array}{l}0.00246^{* * *} \\
(0.000666)\end{array}$ & $\begin{array}{c}-0.000563 \\
(0.000945)\end{array}$ & $\begin{array}{c}0.0220 \\
(0.0213)\end{array}$ \\
\hline EUA & $\begin{array}{c}0.198 \\
(0.115)\end{array}$ & $\begin{array}{l}0.0655^{* *} \\
(0.0225)\end{array}$ & $\begin{array}{c}0.0679 \\
(0.0395)\end{array}$ & $\begin{array}{l}0.741^{* * *} \\
(0.0194)\end{array}$ & $\begin{array}{c}0.148^{* * *} \\
(0.00417)\end{array}$ & $\begin{array}{c}0.163^{* * *} \\
(0.00890)\end{array}$ & $\begin{array}{c}0.888^{* * *} \\
(0.211)\end{array}$ \\
\hline Low & $\begin{array}{c}3.737^{* * *} \\
(0.903)\end{array}$ & $\begin{array}{c}0.983 \\
(0.747)\end{array}$ & $\begin{array}{l}-0.0370 \\
(0.0433)\end{array}$ & $\begin{array}{c}-1.481^{* * *} \\
(0.328)\end{array}$ & $\begin{array}{c}8.029^{* * *} \\
(0.630)\end{array}$ & $\begin{array}{r}-0.00254 \\
(0.0147)\end{array}$ & $\begin{array}{l}-3.269^{*} \\
(1.644)\end{array}$ \\
\hline High & $\begin{array}{c}-6.223^{* * *} \\
(1.105)\end{array}$ & $\begin{array}{l}-0.0311 \\
(0.126)\end{array}$ & $\begin{array}{c}-9.508^{* * *} \\
(1.507)\end{array}$ & $\begin{array}{c}3.425^{* * *} \\
(0.437)\end{array}$ & $\begin{array}{l}-0.00780 \\
(0.0691)\end{array}$ & $\begin{array}{c}12.75^{* * *} \\
(0.694)\end{array}$ & $\begin{array}{c}12.25^{* * *} \\
(2.260)\end{array}$ \\
\hline $\mathrm{CPH}$ & $\begin{array}{c}-14.21^{* * *} \\
(2.119)\end{array}$ & $\begin{array}{c}-5.465^{* * *} \\
(1.132)\end{array}$ & $\begin{array}{l}-0.493 \\
(0.415)\end{array}$ & $\begin{array}{c}-5.229^{* * *} \\
(0.268)\end{array}$ & $\begin{array}{c}-2.217^{* * *} \\
(0.196)\end{array}$ & $\begin{array}{c}-0.0194 \\
(0.0833)\end{array}$ & $\begin{array}{c}-32.25^{* * *} \\
(4.032)\end{array}$ \\
\hline Resdem. $<0$ & $\begin{array}{c}-25.93^{* * *} \\
(0.635)\end{array}$ & $\begin{array}{c}-5.287^{* * *} \\
(1.136)\end{array}$ & $\begin{array}{l}-1.505 \\
(1.581)\end{array}$ & $\begin{array}{c}-3.751^{* * *} \\
(0.184)\end{array}$ & $\begin{array}{c}-0.874^{* * *} \\
(0.220)\end{array}$ & $\begin{array}{l}-0.224 \\
(0.156)\end{array}$ & $\begin{array}{c}-22.67^{* * *} \\
(4.097)\end{array}$ \\
\hline year $=2010$ & $\begin{array}{l}10.55^{*} \\
(4.276)\end{array}$ & $\begin{array}{c}-1.688^{* *} \\
(0.627)\end{array}$ & $\begin{array}{c}6.473^{* * *} \\
(1.505)\end{array}$ & $\begin{array}{c}0.848 \\
(1.123)\end{array}$ & $\begin{array}{c}-0.899^{* * *} \\
(0.220)\end{array}$ & $\begin{array}{c}-1.979^{* * *} \\
(0.271)\end{array}$ & $\begin{array}{c}8.793 \\
(7.259)\end{array}$ \\
\hline year $=2011$ & $\begin{array}{l}11.16^{* *} \\
(4.325)\end{array}$ & $\begin{array}{l}-1.612^{*} \\
(0.657)\end{array}$ & $\begin{array}{c}7.212^{* * *} \\
(1.527)\end{array}$ & $\begin{array}{c}0.815 \\
(1.155)\end{array}$ & $\begin{array}{c}-0.987^{* * *} \\
(0.230)\end{array}$ & $\begin{array}{c}-1.925^{* * *} \\
(0.277)\end{array}$ & $\begin{array}{c}8.341 \\
(7.635)\end{array}$ \\
\hline year $=2012$ & $\begin{array}{l}12.25^{* *} \\
(4.589)\end{array}$ & $\begin{array}{l}-1.716^{*} \\
(0.703)\end{array}$ & $\begin{array}{c}8.192^{* * *} \\
(1.625)\end{array}$ & $\begin{array}{c}1.038 \\
(1.228)\end{array}$ & $\begin{array}{c}-1.169^{* * *} \\
(0.247)\end{array}$ & $\begin{array}{c}-1.660^{* * *} \\
(0.294)\end{array}$ & $\begin{array}{c}7.164 \\
(7.888)\end{array}$ \\
\hline year $=2013$ & $\begin{array}{c}7.245 \\
(4.349)\end{array}$ & $\begin{array}{l}-1.682^{*} \\
(0.725)\end{array}$ & $\begin{array}{c}5.982^{* * *} \\
(1.537)\end{array}$ & $\begin{array}{c}1.117 \\
(1.294)\end{array}$ & $\begin{array}{c}-1.393^{* * *} \\
(0.264)\end{array}$ & $\begin{array}{c}-1.357^{* * *} \\
(0.318)\end{array}$ & $\begin{array}{c}5.752 \\
(7.954)\end{array}$ \\
\hline
\end{tabular}

Note: $\mathrm{N}=35,064$ for all regressions. Standard errors in parentheses, corrected for autocorrelation and heteroskedasticity. Significance levels: ${ }^{*} p<0.05,{ }^{* *} p<0.01,{ }^{* * *} p<0.001$. The column headers refer to the endogenous regressors (fuel costs and allowance costs and their respective interaction with the "Low" and "High" dummies), and RF stands for reduced-form. The coefficients for the monthly dummies are suppressed. 
Table A5: First-stage and reduced-form results from model with yearly, monthly and hourly dummies: All hours and peak/offpeak (corresponding to the second-stage results in columns 5-6 in Table 3

\begin{tabular}{|c|c|c|c|c|c|c|c|c|}
\hline & \multicolumn{3}{|c|}{ Baseload (all hours) } & \multicolumn{5}{|c|}{ Peak vs. offpeak hours } \\
\hline & FC & CC & $\mathrm{RF}$ & FC & FC*Peak & CC & CC*Peak & $\mathrm{RF}$ \\
\hline Coal & $\begin{array}{c}1.663^{* * *} \\
(0.382)\end{array}$ & $\begin{array}{c}-0.0932 \\
(0.0669)\end{array}$ & $\begin{array}{l}1.383^{*} \\
(0.693)\end{array}$ & $\begin{array}{c}1.666^{* * *} \\
(0.373)\end{array}$ & $\begin{array}{c}-0.218 \\
(0.183)\end{array}$ & $\begin{array}{c}-0.123 \\
(0.0674)\end{array}$ & $\begin{array}{c}-0.555^{* * *} \\
(0.0532)\end{array}$ & $\begin{array}{c}1.089 \\
(0.684)\end{array}$ \\
\hline Coal*Peak* & & & & $\begin{array}{l}-0.0395 \\
(0.113)\end{array}$ & $\begin{array}{c}2.220^{* * *} \\
(0.131)\end{array}$ & $\begin{array}{c}0.0911^{* * *} \\
(0.0246)\end{array}$ & $\begin{array}{l}1.540^{* * *} \\
(0.0479)\end{array}$ & $\begin{array}{c}0.819^{* * *} \\
(0.167)\end{array}$ \\
\hline Gas & $\begin{array}{l}-0.807 \\
(0.539)\end{array}$ & $\begin{array}{l}0.0453 \\
(0.143)\end{array}$ & $\begin{array}{l}-0.0259 \\
(0.850)\end{array}$ & $\begin{array}{c}-0.895 \\
(0.532)\end{array}$ & $\begin{array}{l}-0.683^{*} \\
(0.325)\end{array}$ & $\begin{array}{l}0.0637 \\
(0.141)\end{array}$ & $\begin{array}{c}0.249^{*} \\
(0.0993)\end{array}$ & $\begin{array}{l}-0.0914 \\
(0.846)\end{array}$ \\
\hline Gas*Peak & & & & $\begin{array}{l}0.300^{* * *} \\
(0.0540)\end{array}$ & $\begin{array}{l}0.480^{* * *} \\
(0.0632)\end{array}$ & $\begin{array}{c}-0.0623^{* * *} \\
(0.00850)\end{array}$ & $\begin{array}{c}-0.486^{* * *} \\
(0.0185)\end{array}$ & $\begin{array}{c}0.227^{* *} \\
(0.0739)\end{array}$ \\
\hline Gas sqared & $\begin{array}{l}0.0360^{* *} \\
(0.0137)\end{array}$ & $\begin{array}{c}-0.00173 \\
(0.00306)\end{array}$ & $\begin{array}{c}0.0206 \\
(0.0201)\end{array}$ & $\begin{array}{l}0.0356^{* *} \\
(0.0134)\end{array}$ & $\begin{array}{c}0.0190^{*} \\
(0.00801)\end{array}$ & $\begin{array}{c}-0.00166 \\
(0.00303)\end{array}$ & $\begin{array}{c}-0.00291 \\
(0.00227)\end{array}$ & $\begin{array}{c}0.0201 \\
(0.0199)\end{array}$ \\
\hline EUA & $\begin{array}{c}0.199 \\
(0.111)\end{array}$ & $\begin{array}{l}0.741^{* * *} \\
(0.0199)\end{array}$ & $\begin{array}{c}0.887^{* * *} \\
(0.204)\end{array}$ & $\begin{array}{c}0.200 \\
(0.108)\end{array}$ & $\begin{array}{c}0.0423 \\
(0.0601)\end{array}$ & $\begin{array}{l}0.741^{* * *} \\
(0.0198)\end{array}$ & $\begin{array}{l}0.296^{* * *} \\
(0.0198)\end{array}$ & $\begin{array}{c}0.889^{* * *} \\
(0.197)\end{array}$ \\
\hline $\mathrm{CPH}$ & $\begin{array}{c}-11.98^{* * *} \\
(2.120)\end{array}$ & $\begin{array}{c}-5.119^{* * *} \\
(0.264)\end{array}$ & $\begin{array}{c}-23.09^{* * *} \\
(4.543)\end{array}$ & $\begin{array}{c}-11.53^{* * *} \\
(2.125)\end{array}$ & $\begin{array}{c}-0.518 \\
(0.949)\end{array}$ & $\begin{array}{c}-5.158^{* * *} \\
(0.264)\end{array}$ & $\begin{array}{c}-0.862^{* * *} \\
(0.227)\end{array}$ & $\begin{array}{c}-22.21^{* * *} \\
(4.472)\end{array}$ \\
\hline Resdem. $<0$ & $\begin{array}{c}-23.30^{* * *} \\
(0.625)\end{array}$ & $\begin{array}{c}-3.663^{* * *} \\
(0.184)\end{array}$ & $\begin{array}{c}-13.18^{* * *} \\
(3.126)\end{array}$ & $\begin{array}{c}-22.85^{* * *} \\
(0.583)\end{array}$ & $\begin{array}{c}-6.136 \\
(3.257)\end{array}$ & $\begin{array}{c}-3.722^{* * *} \\
(0.223)\end{array}$ & $\begin{array}{c}-1.164^{* *} \\
(0.404)\end{array}$ & $\begin{array}{c}-12.49^{* * *} \\
(2.785)\end{array}$ \\
\hline year $=2010$ & $\begin{array}{c}6.563 \\
(4.276)\end{array}$ & $\begin{array}{c}1.119 \\
(1.138)\end{array}$ & $\begin{array}{c}3.254 \\
(6.940)\end{array}$ & $\begin{array}{l}8.886^{*} \\
(4.245)\end{array}$ & $\begin{array}{l}7.580^{* *} \\
(2.482)\end{array}$ & $\begin{array}{c}0.949 \\
(1.109)\end{array}$ & $\begin{array}{l}-1.451^{*} \\
(0.687)\end{array}$ & $\begin{array}{c}8.207 \\
(6.881)\end{array}$ \\
\hline year $=2011$ & $\begin{array}{c}7.181 \\
(4.353)\end{array}$ & $\begin{array}{c}1.089 \\
(1.170)\end{array}$ & $\begin{array}{c}2.818 \\
(7.332)\end{array}$ & $\begin{array}{l}9.546^{*} \\
(4.321)\end{array}$ & $\begin{array}{c}8.243^{* * *} \\
(2.504)\end{array}$ & $\begin{array}{c}0.916 \\
(1.141)\end{array}$ & $\begin{array}{l}-1.452^{*} \\
(0.699)\end{array}$ & $\begin{array}{c}7.867 \\
(7.260)\end{array}$ \\
\hline year $=2012$ & $\begin{array}{c}8.091 \\
(4.610)\end{array}$ & $\begin{array}{c}1.304 \\
(1.244)\end{array}$ & $\begin{array}{c}1.052 \\
(7.519)\end{array}$ & $\begin{array}{l}10.45^{*} \\
(4.577)\end{array}$ & $\begin{array}{c}9.121^{* * *} \\
(2.684)\end{array}$ & $\begin{array}{c}1.134 \\
(1.214)\end{array}$ & $\begin{array}{l}-1.150 \\
(0.743)\end{array}$ & $\begin{array}{c}6.110 \\
(7.465)\end{array}$ \\
\hline year $=2013$ & $\begin{array}{c}2.942 \\
(4.405)\end{array}$ & $\begin{array}{c}1.377 \\
(1.313)\end{array}$ & $\begin{array}{c}-0.805 \\
(7.511)\end{array}$ & $\begin{array}{c}5.293 \\
(4.377)\end{array}$ & $\begin{array}{l}6.025^{*} \\
(2.631)\end{array}$ & $\begin{array}{c}1.210 \\
(1.282)\end{array}$ & $\begin{array}{c}-0.834 \\
(0.793)\end{array}$ & $\begin{array}{c}4.263 \\
(7.514)\end{array}$ \\
\hline
\end{tabular}

Note: $\mathrm{N}=35,064$ for all regressions. Standard errors in parentheses, corrected for autocorrelation and heteroskedasticity. Significance levels: ${ }^{*} p<0.05,{ }^{* *} p<0.01,{ }^{* * *} p<0.001$. The column headers refer to the endogenous regressors (fuel costs and allowance costs and their respective interaction with the peak dummy), and RF stands for reduced-form. The coefficients for the monthly and hourly dummies are suppressed. 
Table A6: First-stage and reduced-form results from the model with yearly, monthly and hourly dummies: High vs. low vs. other hours (corresponding to the second-stage results in column 3 in Table 4)

\begin{tabular}{|c|c|c|c|c|c|c|c|}
\hline & $\begin{array}{l}\text { (1) } \\
\text { FC }\end{array}$ & $\begin{array}{c}\text { (2) } \\
\text { FC*Low }\end{array}$ & $\begin{array}{c}\text { (3) } \\
\text { FC*High }\end{array}$ & $\begin{array}{l}\text { (4) } \\
\text { CC }\end{array}$ & $\begin{array}{c}\text { (5) } \\
\text { CC*Low }\end{array}$ & $\begin{array}{c}\text { (6) } \\
\text { CC*High }\end{array}$ & $\begin{array}{l}\text { (7) } \\
\text { RF }\end{array}$ \\
\hline Coal & $\begin{array}{c}1.626^{* * *} \\
(0.379)\end{array}$ & $\begin{array}{l}-0.172^{* *} \\
(0.0619)\end{array}$ & $\begin{array}{l}-0.247^{*} \\
(0.126)\end{array}$ & $\begin{array}{c}-0.0834 \\
(0.0656)\end{array}$ & $\begin{array}{c}-0.291^{* * *} \\
(0.0203)\end{array}$ & $\begin{array}{c}-0.169^{* * *} \\
(0.0244)\end{array}$ & $\begin{array}{c}1.314 \\
(0.690)\end{array}$ \\
\hline Coal*Low & $\begin{array}{c}0.0980 \\
(0.0967)\end{array}$ & $\begin{array}{c}2.531^{* * *} \\
(0.101)\end{array}$ & $\begin{array}{c}0.00190 \\
(0.00318)\end{array}$ & $\begin{array}{l}0.00841 \\
(0.0231)\end{array}$ & $\begin{array}{l}1.089^{* * *} \\
(0.0555)\end{array}$ & $\begin{array}{c}0.000135 \\
(0.00127)\end{array}$ & $\begin{array}{l}-0.0484 \\
(0.135)\end{array}$ \\
\hline Coal*High & $\begin{array}{l}0.0283 \\
(0.120)\end{array}$ & $\begin{array}{c}0.0162 \\
(0.0120)\end{array}$ & $\begin{array}{c}2.442^{* * *} \\
(0.189)\end{array}$ & $\begin{array}{l}-0.0541 \\
(0.0292)\end{array}$ & $\begin{array}{c}0.00537 \\
(0.00698)\end{array}$ & $\begin{array}{l}1.023^{* * *} \\
(0.0596)\end{array}$ & $\begin{array}{l}0.464^{* *} \\
(0.174)\end{array}$ \\
\hline Gas & $\begin{array}{c}-0.781 \\
(0.532)\end{array}$ & $\begin{array}{c}0.204^{*} \\
(0.0849)\end{array}$ & $\begin{array}{c}-0.498^{* *} \\
(0.179)\end{array}$ & $\begin{array}{l}0.0466 \\
(0.138)\end{array}$ & $\begin{array}{c}0.0515 \\
(0.0298)\end{array}$ & $\begin{array}{l}0.0980^{*} \\
(0.0408)\end{array}$ & $\begin{array}{l}0.0933 \\
(0.852)\end{array}$ \\
\hline Gas*Low & $\begin{array}{c}-0.351^{* * *} \\
(0.0382)\end{array}$ & $\begin{array}{l}-0.0171 \\
(0.0283)\end{array}$ & $\begin{array}{c}0.00106 \\
(0.00161)\end{array}$ & $\begin{array}{l}0.0657^{* * *} \\
(0.00860)\end{array}$ & $\begin{array}{c}-0.504^{* * *} \\
(0.0144)\end{array}$ & $\begin{array}{c}0.0000578 \\
(0.000371)\end{array}$ & $\begin{array}{c}-0.257^{* * *} \\
(0.0457)\end{array}$ \\
\hline Gas*High & $\begin{array}{l}0.438^{* * *} \\
(0.0552)\end{array}$ & $\begin{array}{c}-0.0102^{*} \\
(0.00447)\end{array}$ & $\begin{array}{l}0.809^{* * *} \\
(0.0836)\end{array}$ & $\begin{array}{c}-0.128^{* * *} \\
(0.0117)\end{array}$ & $\begin{array}{l}-0.00381^{*} \\
(0.00192)\end{array}$ & $\begin{array}{c}-0.683^{* * *} \\
(0.0175)\end{array}$ & $\begin{array}{c}-0.349^{* * *} \\
(0.0638)\end{array}$ \\
\hline Gas sqared & $\begin{array}{l}0.0356^{* *} \\
(0.0135)\end{array}$ & $\begin{array}{l}-0.00332 \\
(0.00204)\end{array}$ & $\begin{array}{c}0.0126^{* *} \\
(0.00444)\end{array}$ & $\begin{array}{c}-0.00161 \\
(0.00295)\end{array}$ & $\begin{array}{l}0.00246^{* * *} \\
(0.000663)\end{array}$ & $\begin{array}{c}-0.000561 \\
(0.000947)\end{array}$ & $\begin{array}{c}0.0208 \\
(0.0202)\end{array}$ \\
\hline EUA & $\begin{array}{c}0.199 \\
(0.111)\end{array}$ & $\begin{array}{l}0.0655^{* *} \\
(0.0224)\end{array}$ & $\begin{array}{c}0.0685 \\
(0.0396)\end{array}$ & $\begin{array}{l}0.741^{* * *} \\
(0.0195)\end{array}$ & $\begin{array}{c}0.148^{* * *} \\
(0.00419)\end{array}$ & $\begin{array}{c}0.163^{* * *} \\
(0.00893)\end{array}$ & $\begin{array}{c}0.886^{* * *} \\
(0.204)\end{array}$ \\
\hline $\mathrm{CPH}$ & $\begin{array}{c}-11.69^{* * *} \\
(2.126)\end{array}$ & $\begin{array}{c}-5.108^{* * *} \\
(1.138)\end{array}$ & $\begin{array}{l}-0.508 \\
(0.430)\end{array}$ & $\begin{array}{c}-5.188^{* * *} \\
(0.263)\end{array}$ & $\begin{array}{c}-2.222^{* * *} \\
(0.198)\end{array}$ & $\begin{array}{c}-0.0206 \\
(0.0865)\end{array}$ & $\begin{array}{c}-23.09^{* * *} \\
(4.538)\end{array}$ \\
\hline Resdem. $<0$ & $\begin{array}{c}-23.12^{* * *} \\
(0.679)\end{array}$ & $\begin{array}{c}-5.192^{* * *} \\
(1.062)\end{array}$ & $\begin{array}{c}-1.483 \\
(1.561)\end{array}$ & $\begin{array}{c}-3.710^{* * *} \\
(0.195)\end{array}$ & $\begin{array}{c}-0.900^{* * *} \\
(0.201)\end{array}$ & $\begin{array}{c}-0.229 \\
(0.159)\end{array}$ & $\begin{array}{c}-13.43^{* * *} \\
(3.095)\end{array}$ \\
\hline year $=2010$ & $\begin{array}{l}13.66^{* *} \\
(4.408)\end{array}$ & $\begin{array}{l}-1.348 \\
(0.818)\end{array}$ & $\begin{array}{c}6.428^{* * *} \\
(1.512)\end{array}$ & $\begin{array}{c}-0.682 \\
(1.104)\end{array}$ & $\begin{array}{c}7.142^{* * *} \\
(0.651)\end{array}$ & $\begin{array}{c}-1.982^{* * *} \\
(0.270)\end{array}$ & $\begin{array}{c}7.528 \\
(6.993)\end{array}$ \\
\hline year $=2011$ & $\begin{array}{l}14.28^{* *} \\
(4.454)\end{array}$ & $\begin{array}{l}-1.269 \\
(0.851)\end{array}$ & $\begin{array}{c}7.167^{* * *} \\
(1.534)\end{array}$ & $\begin{array}{c}-0.714 \\
(1.134)\end{array}$ & $\begin{array}{c}7.055^{* * *} \\
(0.659)\end{array}$ & $\begin{array}{c}-1.928^{* * *} \\
(0.277)\end{array}$ & $\begin{array}{c}7.088 \\
(7.348)\end{array}$ \\
\hline year $=2012$ & $\begin{array}{l}15.18^{* *} \\
(4.699)\end{array}$ & $\begin{array}{l}-1.393 \\
(0.892)\end{array}$ & $\begin{array}{c}8.149^{* * *} \\
(1.634)\end{array}$ & $\begin{array}{c}-0.494 \\
(1.194)\end{array}$ & $\begin{array}{c}6.873^{* * *} \\
(0.670)\end{array}$ & $\begin{array}{c}-1.663^{* * *} \\
(0.293)\end{array}$ & $\begin{array}{c}5.319 \\
(7.554)\end{array}$ \\
\hline year $=2013$ & $\begin{array}{c}10.02^{*} \\
(4.433)\end{array}$ & $\begin{array}{c}-1.372 \\
(0.925)\end{array}$ & $\begin{array}{c}5.937^{* * *} \\
(1.545)\end{array}$ & $\begin{array}{c}-0.419 \\
(1.254)\end{array}$ & $\begin{array}{c}6.649^{* * *} \\
(0.676)\end{array}$ & $\begin{array}{c}-1.360^{* * *} \\
(0.317)\end{array}$ & $\begin{array}{c}3.462 \\
(7.517)\end{array}$ \\
\hline
\end{tabular}

Note: $\mathrm{N}=35,064$ for all regressions. Standard errors in parentheses, corrected for autocorrelation and heteroskedasticity. Significance levels: ${ }^{*} p<0.05,{ }^{* *} p<0.01,{ }^{* * *} p<0.001$. The column headers refer to the endogenous regressors (fuel costs and allowance costs and their respective interaction with the "Low" and "High" dummies), and RF stands for reduced-form. The coefficients for the monthly and hourly dummies are suppressed. 
Table A7: First-stage and reduced-form results from model without the allowance price, for all hours and peak/offpeak (corresponding to the second-stage results in columns 7-8 in Table 3)

\begin{tabular}{|c|c|c|c|c|c|c|c|c|}
\hline & \multicolumn{3}{|c|}{ Baseload (all hours) } & \multicolumn{5}{|c|}{ Peak vs. offpeak hours } \\
\hline & FC & CC & $\mathrm{RF}$ & FC & FC*Peak & CC & CC*Peak & $\mathrm{RF}$ \\
\hline Coal & $\begin{array}{c}2.643^{* * *} \\
(0.171)\end{array}$ & $\begin{array}{l}1.024^{* * *} \\
(0.0641)\end{array}$ & $\begin{array}{c}3.656^{* * *} \\
(0.263)\end{array}$ & $\begin{array}{c}2.636^{* * *} \\
(0.163)\end{array}$ & $\begin{array}{c}0.126 \\
(0.0855)\end{array}$ & $\begin{array}{l}1.030^{* * *} \\
(0.0643)\end{array}$ & $\begin{array}{c}-0.0359 \\
(0.0196)\end{array}$ & $\begin{array}{c}3.580^{* * *} \\
(0.245)\end{array}$ \\
\hline Coal*Peak* & & & & $\begin{array}{l}0.0183 \\
(0.134)\end{array}$ & $\begin{array}{c}2.530^{* * *} \\
(0.159)\end{array}$ & $\begin{array}{c}-0.0157 \\
(0.0421)\end{array}$ & $\begin{array}{l}1.083^{* * *} \\
(0.0599)\end{array}$ & $\begin{array}{c}0.240 \\
(0.236)\end{array}$ \\
\hline Gas & $\begin{array}{c}-0.696 \\
(0.629)\end{array}$ & $\begin{array}{c}-0.385 \\
(0.205)\end{array}$ & $\begin{array}{c}-2.355^{* *} \\
(0.851)\end{array}$ & $\begin{array}{c}-0.799 \\
(0.624)\end{array}$ & $\begin{array}{c}-0.622 \\
(0.386)\end{array}$ & $\begin{array}{c}-0.355 \\
(0.204)\end{array}$ & $\begin{array}{c}0.164 \\
(0.0867)\end{array}$ & $\begin{array}{c}-2.383^{* *} \\
(0.812)\end{array}$ \\
\hline Gas*Peak & & & & $\begin{array}{l}0.301^{* * *} \\
(0.0561)\end{array}$ & $\begin{array}{l}0.553^{* * *} \\
(0.0667)\end{array}$ & $\begin{array}{c}-0.0977^{* * *} \\
(0.0128)\end{array}$ & $\begin{array}{c}-0.628^{* * *} \\
(0.0186)\end{array}$ & $\begin{array}{r}-0.00759 \\
(0.0800)\end{array}$ \\
\hline Gas sqared & $\begin{array}{c}0.0259 \\
(0.0156)\end{array}$ & $\begin{array}{c}-0.00414 \\
(0.00493)\end{array}$ & $\begin{array}{c}0.0531^{*} \\
(0.0207)\end{array}$ & $\begin{array}{c}0.0259 \\
(0.0154)\end{array}$ & $\begin{array}{c}0.0152 \\
(0.00928)\end{array}$ & $\begin{array}{c}-0.00405 \\
(0.00488)\end{array}$ & $\begin{array}{l}-0.00385 \\
(0.00209)\end{array}$ & $\begin{array}{l}0.0539^{* *} \\
(0.0199)\end{array}$ \\
\hline Peak & & & & $\begin{array}{c}-3.557^{* *} \\
(1.255)\end{array}$ & $\begin{array}{c}-6.499^{* * *} \\
(1.415)\end{array}$ & $\begin{array}{c}2.315^{* * *} \\
(0.515)\end{array}$ & $\begin{array}{c}10.84^{* * *} \\
(0.735)\end{array}$ & $\begin{array}{c}8.513^{* * *} \\
(2.479)\end{array}$ \\
\hline $\mathrm{CPH}$ & $\begin{array}{c}-15.80^{* * *} \\
(2.102)\end{array}$ & $\begin{array}{c}-5.743^{* * *} \\
(0.348)\end{array}$ & $\begin{array}{c}-35.60^{* * *} \\
(4.098)\end{array}$ & $\begin{array}{c}-15.19^{* * *} \\
(2.073)\end{array}$ & $\begin{array}{c}-1.833 \\
(1.011)\end{array}$ & $\begin{array}{c}-5.810^{* * *} \\
(0.347)\end{array}$ & $\begin{array}{c}-1.111^{* * *} \\
(0.227)\end{array}$ & $\begin{array}{c}-34.21^{* * *} \\
(3.974)\end{array}$ \\
\hline Resdem. $<0$ & $\begin{array}{c}-27.79^{* * *} \\
(0.485)\end{array}$ & $\begin{array}{c}-3.841^{* * *} \\
(0.116)\end{array}$ & $\begin{array}{c}-24.03^{* * *} \\
(4.517)\end{array}$ & $\begin{array}{c}-27.48^{* * *} \\
(0.652)\end{array}$ & $\begin{array}{l}-8.875^{*} \\
(3.918)\end{array}$ & $\begin{array}{c}-3.875^{* * *} \\
(0.125)\end{array}$ & $\begin{array}{l}-1.086^{*} \\
(0.465)\end{array}$ & $\begin{array}{c}-23.39^{* * *} \\
(5.773)\end{array}$ \\
\hline Constant & $\begin{array}{c}4.863 \\
(4.593)\end{array}$ & $\begin{array}{c}8.263^{* * *} \\
(1.698)\end{array}$ & $\begin{array}{c}32.71^{* * *} \\
(6.824)\end{array}$ & $\begin{array}{c}6.084 \\
(4.613)\end{array}$ & $\begin{array}{c}4.766 \\
(2.937)\end{array}$ & $\begin{array}{c}7.484^{* * *} \\
(1.690)\end{array}$ & $\begin{array}{c}-1.271 \\
(0.656)\end{array}$ & $\begin{array}{c}29.95^{* * *} \\
(6.484)\end{array}$ \\
\hline
\end{tabular}

Note: $\mathrm{N}=35,064$ for all regressions. Standard errors in parentheses, corrected for autocorrelation and heteroskedasticity. Significance levels: ${ }^{*} p<0.05,{ }^{* *} p<0.01,{ }^{* * *} p<0.001$. The column headers refer to the endogenous regressors (fuel costs and allowance costs and their respective interaction with the Peak dummy), and RF stands for reduced-form. 
Table A8: First-stage and reduced-form results from model without the allowance price: High vs. low vs. other hours (corresponding to the second-stage results in column 4 in Table 4)

\begin{tabular}{|c|c|c|c|c|c|c|c|}
\hline & $\begin{array}{l}(1) \\
\text { FC }\end{array}$ & $\begin{array}{c}(2) \\
\text { FC*Low }\end{array}$ & $\begin{array}{c}\text { (3) } \\
\text { FC*High }\end{array}$ & $\begin{array}{l}\text { (4) } \\
\text { CC }\end{array}$ & $\begin{array}{c}\text { (5) } \\
\text { CC*Low }\end{array}$ & $\begin{array}{c}(6) \\
\text { CC*High }\end{array}$ & $\begin{array}{l}\text { (7) } \\
\text { RF }\end{array}$ \\
\hline Coal & $\begin{array}{c}2.609^{* * *} \\
(0.174)\end{array}$ & $\begin{array}{c}-0.065^{* * *} \\
(0.019)\end{array}$ & $\begin{array}{c}0.062 \\
(0.054)\end{array}$ & $\begin{array}{c}1.031^{* * *} \\
(0.065)\end{array}$ & $\begin{array}{c}0.010 \\
(0.011)\end{array}$ & $\begin{array}{l}-0.017 \\
(0.010)\end{array}$ & $\begin{array}{c}3.575^{* * *} \\
(0.280)\end{array}$ \\
\hline Coal*Low & $\begin{array}{c}0.107 \\
(0.102)\end{array}$ & $\begin{array}{c}2.533^{* * *} \\
(0.102)\end{array}$ & $\begin{array}{c}0.002 \\
(0.002)\end{array}$ & $\begin{array}{c}0.011 \\
(0.023)\end{array}$ & $\begin{array}{c}1.089^{* * *} \\
(0.055)\end{array}$ & $\begin{array}{c}0.000 \\
(0.000)\end{array}$ & $\begin{array}{c}-0.019 \\
(0.164)\end{array}$ \\
\hline Coal*High & $\begin{array}{c}0.035 \\
(0.140)\end{array}$ & $\begin{array}{c}0.017 \\
(0.012)\end{array}$ & $\begin{array}{c}2.443^{* * *} \\
(0.191)\end{array}$ & $\begin{array}{c}-0.053 \\
(0.038)\end{array}$ & $\begin{array}{c}0.006 \\
(0.004)\end{array}$ & $\begin{array}{c}1.023^{* * *} \\
(0.061)\end{array}$ & $\begin{array}{c}0.478^{*} \\
(0.212)\end{array}$ \\
\hline Gas & $\begin{array}{c}-0.670 \\
(0.620)\end{array}$ & $\begin{array}{l}0.200^{* *} \\
(0.069)\end{array}$ & $\begin{array}{c}-0.302 \\
(0.244)\end{array}$ & $\begin{array}{c}-0.381 \\
(0.204)\end{array}$ & $\begin{array}{c}-0.078 \\
(0.049)\end{array}$ & $\begin{array}{c}0.076 \\
(0.045)\end{array}$ & $\begin{array}{c}-2.215^{* *} \\
(0.823)\end{array}$ \\
\hline Gas*Low & $\begin{array}{c}-0.346^{* * *} \\
(0.039)\end{array}$ & $\begin{array}{c}-0.016 \\
(0.028)\end{array}$ & $\begin{array}{c}0.001 \\
(0.001)\end{array}$ & $\begin{array}{c}0.067^{* * *} \\
(0.009)\end{array}$ & $\begin{array}{c}-0.504^{* * *} \\
(0.015)\end{array}$ & $\begin{array}{c}0.000 \\
(0.000)\end{array}$ & $\begin{array}{c}-0.238^{* * *} \\
(0.054)\end{array}$ \\
\hline Gas*High & $\begin{array}{c}0.429^{* * *} \\
(0.056)\end{array}$ & $\begin{array}{l}-0.011^{*} \\
(0.005)\end{array}$ & $\begin{array}{c}0.807^{* * *} \\
(0.084)\end{array}$ & $\begin{array}{c}-0.131^{* * *} \\
(0.013)\end{array}$ & $\begin{array}{c}-0.004^{* *} \\
(0.001)\end{array}$ & $\begin{array}{c}-0.683^{* * *} \\
(0.018)\end{array}$ & $\begin{array}{c}-0.369^{* * *} \\
(0.075)\end{array}$ \\
\hline Gas sqared & $\begin{array}{c}0.025 \\
(0.015)\end{array}$ & $\begin{array}{c}-0.004^{* *} \\
(0.002)\end{array}$ & $\begin{array}{c}0.007 \\
(0.006)\end{array}$ & $\begin{array}{c}-0.004 \\
(0.005)\end{array}$ & $\begin{array}{c}0.002 \\
(0.001)\end{array}$ & $\begin{array}{c}-0.002 \\
(0.001)\end{array}$ & $\begin{array}{l}0.053^{* *} \\
(0.020)\end{array}$ \\
\hline Low & $\begin{array}{c}3.731^{* * *} \\
(0.900)\end{array}$ & $\begin{array}{c}0.976 \\
(0.744)\end{array}$ & $\begin{array}{c}-0.034 \\
(0.030)\end{array}$ & $\begin{array}{c}-1.518^{* * *} \\
(0.337)\end{array}$ & $\begin{array}{c}8.019^{* * *} \\
(0.628)\end{array}$ & $\begin{array}{c}-0.009 \\
(0.006)\end{array}$ & $\begin{array}{l}-3.296^{*} \\
(1.644)\end{array}$ \\
\hline High & $\begin{array}{c}-6.180^{* * *} \\
(1.124)\end{array}$ & $\begin{array}{c}-0.020 \\
(0.117)\end{array}$ & $\begin{array}{c}-9.499^{* * *} \\
(1.522)\end{array}$ & $\begin{array}{c}3.454^{* * *} \\
(0.518)\end{array}$ & $\begin{array}{c}0.001 \\
(0.046)\end{array}$ & $\begin{array}{c}12.753^{* * *} \\
(0.704)\end{array}$ & $\begin{array}{c}12.363^{* * *} \\
(2.294)\end{array}$ \\
\hline $\mathrm{CPH}$ & $\begin{array}{c}-14.450^{* * *} \\
(2.094)\end{array}$ & $\begin{array}{c}-5.602^{* * *} \\
(1.142)\end{array}$ & $\begin{array}{c}-0.474 \\
(0.383)\end{array}$ & $\begin{array}{c}-5.845^{* * *} \\
(0.345)\end{array}$ & $\begin{array}{c}-2.392^{* * *} \\
(0.227)\end{array}$ & $\begin{array}{l}-0.116 \\
(0.061)\end{array}$ & $\begin{array}{c}-32.995^{* * *} \\
(4.080)\end{array}$ \\
\hline Resdem. $<0$ & $\begin{array}{c}-27.183^{* * *} \\
(0.581)\end{array}$ & $\begin{array}{c}-5.263^{* * *} \\
(1.130)\end{array}$ & $\begin{array}{c}-2.070 \\
(1.615)\end{array}$ & $\begin{array}{c}-3.896^{* * *} \\
(0.120)\end{array}$ & $\begin{array}{c}-0.944^{* * *} \\
(0.194)\end{array}$ & $\begin{array}{c}-0.199 \\
(0.154)\end{array}$ & $\begin{array}{c}-23.387^{* * *} \\
(4.942)\end{array}$ \\
\hline Constant & $\begin{array}{c}4.900 \\
(4.564)\end{array}$ & $\begin{array}{l}-1.363^{*} \\
(0.553)\end{array}$ & $\begin{array}{c}2.328 \\
(1.856)\end{array}$ & $\begin{array}{c}8.051^{* * *} \\
(1.708)\end{array}$ & $\begin{array}{c}0.652 \\
(0.373)\end{array}$ & $\begin{array}{c}-0.571 \\
(0.338)\end{array}$ & $\begin{array}{c}31.215^{* * *} \\
(6.585)\end{array}$ \\
\hline
\end{tabular}

Note: $\mathrm{N}=35,064$ for all regressions. Standard errors in parentheses, corrected for autocorrelation and heteroskedasticity. Significance levels: ${ }^{*} p<0.05,{ }^{* *} p<0.01,{ }^{* * *} p<0.001$. The column headers refer to the endogenous regressors (fuel costs and allowance costs and their respective interaction with the "Low" and "High" dummies), and RF stands for reduced-form. 
Figure A1: Robustness check: Changing residual demand by +/- 2GW
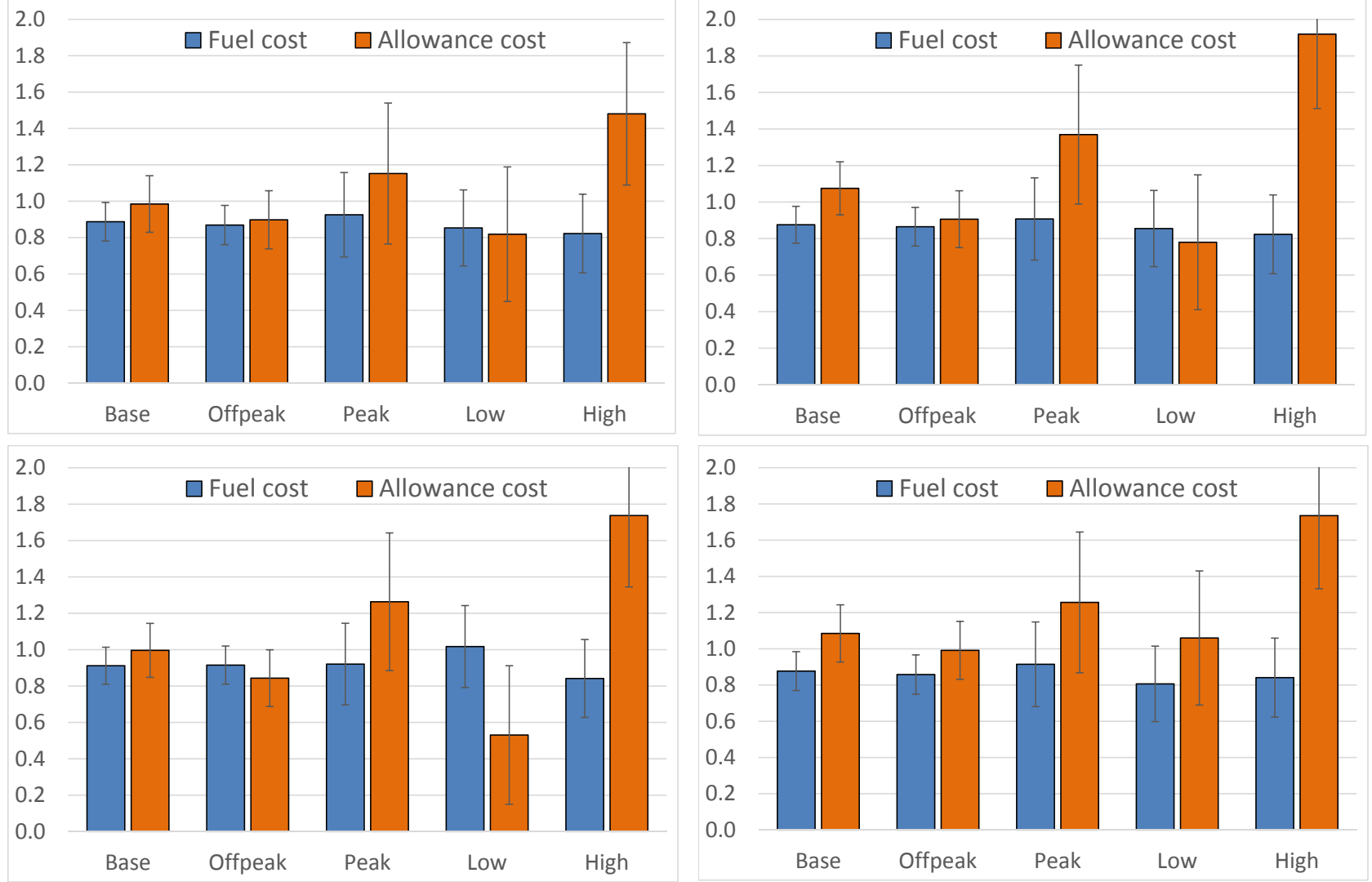

Estimates for cost pass-through from the base model, after changing residual demand during hours of high demand (top left: $-2 \mathrm{GW}$; top right: $+2 \mathrm{GW}$ ), and during hours of low demand (bottom left: $-2 \mathrm{GW}$; bottom right: $+2 \mathrm{GW})$. 
Table A9: Results from price regression. Dependent variable: Electricity price

\begin{tabular}{|c|c|c|c|c|c|c|}
\hline & \multicolumn{3}{|c|}{ Base model } & \multicolumn{3}{|c|}{ Including $\mathrm{Y} / \mathrm{M} / \mathrm{W}-\mathrm{H}$ dummies } \\
\hline & Baseload & Peak/Offp. & Low/High & Baseload & Peak/Offp. & Low/High \\
\hline Gas & $\begin{array}{c}0.746^{* * *} \\
(0.139)\end{array}$ & $\begin{array}{c}0.653^{* * *} \\
(0.149)\end{array}$ & $\begin{array}{c}0.856^{* * *} \\
(0.138)\end{array}$ & $\begin{array}{c}0.264 \\
(0.249)\end{array}$ & $\begin{array}{c}0.00669 \\
(0.257)\end{array}$ & $\begin{array}{c}0.351 \\
(0.249)\end{array}$ \\
\hline Coal & $\begin{array}{l}1.330^{* * *} \\
(0.334)\end{array}$ & $\begin{array}{c}1.333^{* * *} \\
(0.345)\end{array}$ & $\begin{array}{l}1.361^{* * *} \\
(0.337)\end{array}$ & $\begin{array}{l}1.376^{*} \\
(0.596)\end{array}$ & $\begin{array}{l}1.460^{*} \\
(0.607)\end{array}$ & $\begin{array}{l}1.362^{*} \\
(0.597)\end{array}$ \\
\hline EUA & $\begin{array}{l}1.079^{* * *} \\
(0.147)\end{array}$ & $\begin{array}{c}0.953^{* * *} \\
(0.150)\end{array}$ & $\begin{array}{c}0.864^{* * *} \\
(0.150)\end{array}$ & $\begin{array}{c}0.853^{* * *} \\
(0.190)\end{array}$ & $\begin{array}{c}0.774^{* * *} \\
(0.191)\end{array}$ & $\begin{array}{c}0.840^{* * *} \\
(0.196)\end{array}$ \\
\hline rese & $\begin{array}{c}-0.410^{* * *} \\
(0.0536)\end{array}$ & $\begin{array}{c}-0.734^{* * *} \\
(0.0570)\end{array}$ & $\begin{array}{c}-0.906^{* * *} \\
(0.0541)\end{array}$ & $\begin{array}{c}-0.938^{* * *} \\
(0.0510)\end{array}$ & $\begin{array}{c}-0.958^{* * *} \\
(0.0532)\end{array}$ & $\begin{array}{c}-0.955^{* * *} \\
(0.0525)\end{array}$ \\
\hline HDD & $\begin{array}{l}0.337^{* * *} \\
(0.0512)\end{array}$ & $\begin{array}{l}0.310^{* * *} \\
(0.0470)\end{array}$ & $\begin{array}{l}0.305^{* * *} \\
(0.0464)\end{array}$ & $\begin{array}{c}0.688^{* * *} \\
(0.100)\end{array}$ & $\begin{array}{l}0.676^{* * *} \\
(0.0937)\end{array}$ & $\begin{array}{c}0.683^{* * *} \\
(0.100)\end{array}$ \\
\hline CDD & $\begin{array}{c}0.696 \\
(0.614)\end{array}$ & $\begin{array}{c}0.593 \\
(0.566)\end{array}$ & $\begin{array}{c}0.743 \\
(0.532)\end{array}$ & $\begin{array}{c}1.706^{* * *} \\
(0.321)\end{array}$ & $\begin{array}{l}1.717^{* * *} \\
(0.315)\end{array}$ & $\begin{array}{c}1.716^{* * *} \\
(0.319)\end{array}$ \\
\hline Gas*Peak & & $\begin{array}{c}0.286 \\
(0.159)\end{array}$ & & & $\begin{array}{c}0.693^{* * *} \\
(0.120)\end{array}$ & \\
\hline Gas*Low & & & $\begin{array}{c}-0.535^{* * *} \\
(0.101)\end{array}$ & & & $\begin{array}{c}-0.540^{* * *} \\
(0.0859)\end{array}$ \\
\hline Gas*High & & & $\begin{array}{c}0.203 \\
(0.137)\end{array}$ & & & $\begin{array}{c}0.232 \\
(0.120)\end{array}$ \\
\hline Coal*Peak* & & $\begin{array}{c}0.114 \\
(0.372)\end{array}$ & & & $\begin{array}{l}-0.199 \\
(0.288)\end{array}$ & \\
\hline Coal*Low & & & $\begin{array}{c}0.391 \\
(0.237)\end{array}$ & & & $\begin{array}{l}0.411^{*} \\
(0.200)\end{array}$ \\
\hline Coal*High & & & $\begin{array}{l}-0.412 \\
(0.327)\end{array}$ & & & $\begin{array}{l}-0.438 \\
(0.275)\end{array}$ \\
\hline EUA*Peak & & $\begin{array}{l}-0.0454 \\
(0.163)\end{array}$ & & & $\begin{array}{l}0.234^{*} \\
(0.115)\end{array}$ & \\
\hline EUA*Low & & & $\begin{array}{l}-0.126 \\
(0.105)\end{array}$ & & & $\begin{array}{c}-0.125 \\
(0.0869)\end{array}$ \\
\hline EUA*High & & & $\begin{array}{c}0.223 \\
(0.141)\end{array}$ & & & $\begin{array}{c}0.229 \\
(0.122)\end{array}$ \\
\hline Peak & & $\begin{array}{l}6.505^{*} \\
(2.870)\end{array}$ & & & & \\
\hline Low & & & $\begin{array}{c}-1.791 \\
(1.791)\end{array}$ & & & \\
\hline High & & & $\begin{array}{c}10.84^{* * *} \\
(2.578)\end{array}$ & & & \\
\hline Constant & $\begin{array}{c}3.016 \\
(2.878)\end{array}$ & $\begin{array}{c}4.422 \\
(2.821)\end{array}$ & $\begin{array}{l}6.991^{*} \\
(2.981)\end{array}$ & $\begin{array}{c}4.341 \\
(4.843)\end{array}$ & $\begin{array}{c}11.07^{*} \\
(4.655)\end{array}$ & $\begin{array}{l}12.41^{* *} \\
(4.744)\end{array}$ \\
\hline Observations & 35064 & 35064 & 35064 & 35064 & 35064 & 35064 \\
\hline
\end{tabular}

Note: $\mathrm{N}=35,064$. Standard errors in parentheses, corrected for autocorrelation and heteroskedasticity. Significance levels: ${ }^{*} p<0.05,{ }^{* *} p<0.01,{ }^{* * *} p<0.001$. 